\title{
People's Republic of China: Financial System Stability Assessment
}

This financial sector stability assessment on the People's Republic of China was prepared by a staff team of the International Monetary Fund as background documentation for the periodic consultation with the member country. It is based on the information available at the time it was completed on June 24, 2011. The views expressed in this document are those of the staff team and do not necessarily reflect the views of the government of the People's Republic of China or the Executive Board of the IMF.

The policy of publication of staff reports and other documents by the IMF allows for the deletion of market-sensitive information.

Copies of this report are available to the public from

International Monetary Fund • Publication Services

$70019^{\text {th }}$ Street, N.W. • Washington, D.C. 20431

Telephone: (202) 623-7430 • Telefax: (202) 623-7201

E-mail: publications@imf.org Internet: http://www.imf.org

\section{International Monetary Fund Washington, D.C.}




\title{
INTERNATIONAL MONETARY FUND
}

\author{
PEOPLE'S REPUBLIC OF CHINA
}

\section{Financial System Stability Assessment}

\author{
Prepared by the Monetary and Capital Markets and Asia and Pacific Departments
}

\author{
Approved by José Viñals and Anoop Singh
}

June 24, 2011

\begin{abstract}
This report is based on the IMF/World Bank Financial Sector Assessment Program (FSAP) exercise for China undertaken during June-December 2010. The assessment concluded that reforms have progressed well in moving to a more commercially-oriented financial system. Despite success and rapid growth, China's financial sector is confronting several near-term risks, structural challenges, and policy-induced distortions. The main sources of risks are: (i) the effects of a rapid crisis-related credit expansion on credit quality, (ii) growing off-balance sheet exposures and disintermediation, (iii) a reversal in rapidly rising real estate prices, and (iv) an increase in imbalances due to the current economic growth pattern. Medium-term vulnerabilities - the relatively inflexible macroeconomic policy framework, and the government's important role in credit allocation and in the financial sector at the central and provincial levels - are building up contingent liabilities and could impair the needed reorientation of the financial system to support China's future growth.
\end{abstract}

A properly composed and timely implemented set of reforms would help address these challenges. This will require further progress in multiple areas, including (i) deepening the commercial orientation of banks and other financial firms; (ii) moving to more market-based means of influencing monetary and financial conditions; (iii) continued strengthening of the capacity of the central bank on financial stability issues, and that of the supervisory commissions; (iv) further development of financial markets and instruments to deepen and strengthen China's financial system; and (v) upgrading the framework for financial stability, crisis management, and resolution arrangement. Moving along this path, however, will pose additional risks and new situations. Hence, priority must be given to establishing the institutional and operational preconditions that are crucial to successfully managing a wide-ranging financial reform agenda, and the intent outlined in the latest $12^{\text {th }}$ Five-Year Plan.

The FSAP team comprised Jonathan Fiechter (IMF, Mission Co-Chief), Thomas A. Rose (World Bank, Mission CoChief), Udaibir S. Das (Deputy Mission Chief, IMF), Mario Guadamillas (Deputy Mission Chief, World Bank), César Arias, Martin Čihák, Silvia Iorgova, Yinqiu Lu, Aditya Narain, Nathan Porter, Shaun Roache, Tao Sun, Murtaza Syed (all IMF); Massimo Cirasino, Patrick Conroy, Asli Demirgüç-Kunt, Catiana Garcia-Kilroy, Haocong Ren, Heinz Rudolph, Jun Wang, Ying Wang, Luan Zhao (all World Bank); Nuno Cassola, Henning Göbel, Keith Hall, Nick Le Pan, Greg Tanzer, Nancy Wentzler, Rodney Lester, and Walter Yao (all experts). The team met senior officials and staff from relevant government agencies, as well as representatives from financial institutions, industry organizations, and private sector representatives in Beijing, Chongqing, Nanchang, Ningbo, Shanghai, and Shenzhen.

Subsequent to the FSAP mission, the authorities have begun to move on the various FSAP recommendations, and have asked for technical cooperation in several areas relating to the existing financial stability framework.

The main authors of this report are Udaibir S. Das, Martin Čihák, and Yinqiu Lu with contributions from the FSAP team.

FSAP assessments are designed to assess the stability of the financial system as a whole and not that of individual institutions. They have been developed to help countries identify and remedy weaknesses in their financial sector structure, thereby enhancing their resilience to macroeconomic shocks and cross-border contagion. FSAP assessments do not cover risks that are specific to individual institutions such as asset quality, operational or legal risks, or fraud. 


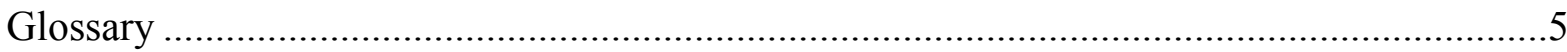

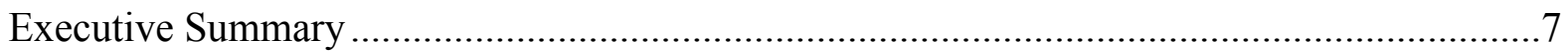

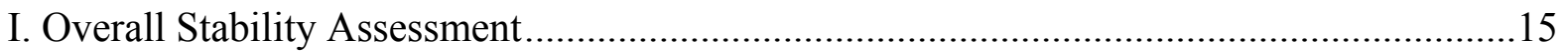

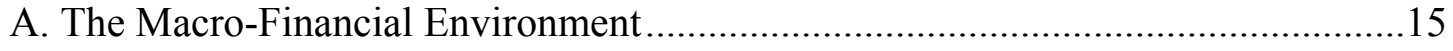

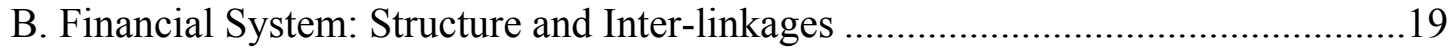

C. Banking System Performance, Soundness, and Resilience...................................25

D. Stress-Testing Results Summary ................................................................29

II. Managing Risks: Upgrading the Crisis Toolkit...........................................................36

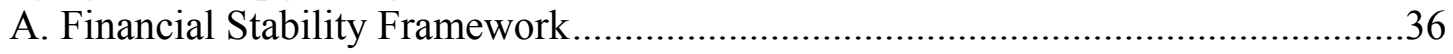

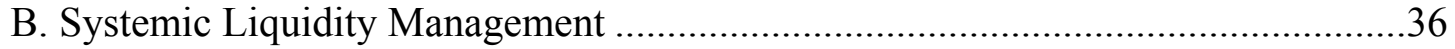

C. Crisis Management, Resolution, and Deposit Insurance.....................................37

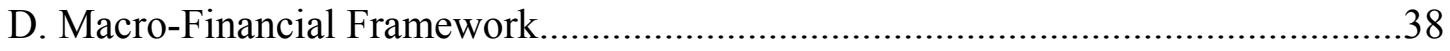

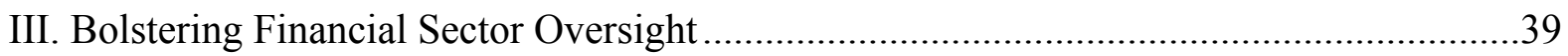

A. Commercial Bank Regulation and Supervision ............................................4

B. Securities Intermediaries and Securities Market Regulation ...............................42

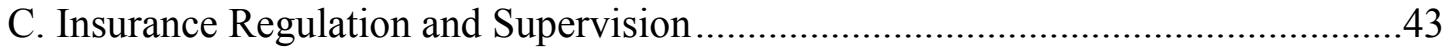

IV. Upgrading the Financial Infrastructure and Legal Framework .....................................44

A. Payment and Securities Settlements Systems ..................................................44

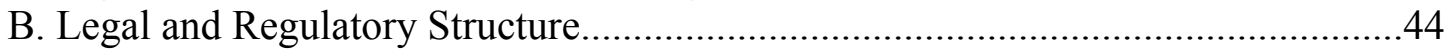

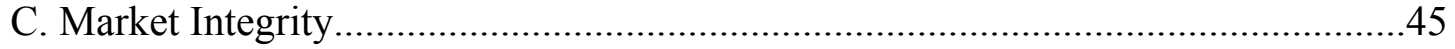

V. Broadening Financial Markets and Services.............................................................45

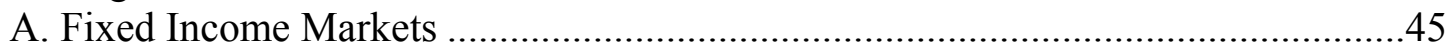

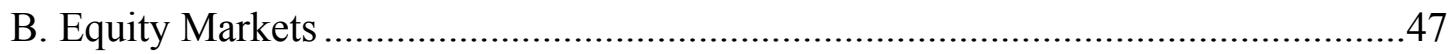

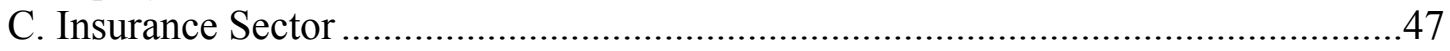

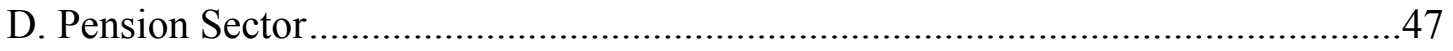

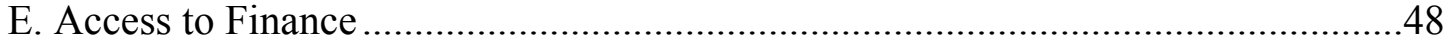

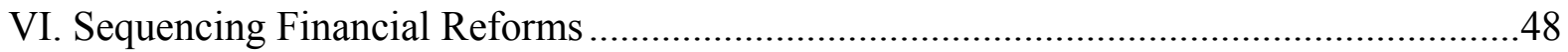

Tables

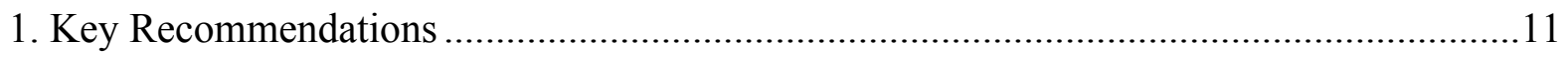

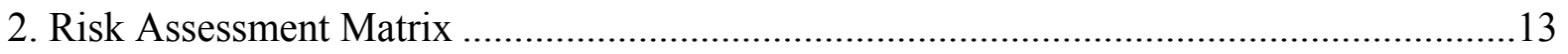

3. Financial Sector Reforms - Selected Benchmarks ...................................................20

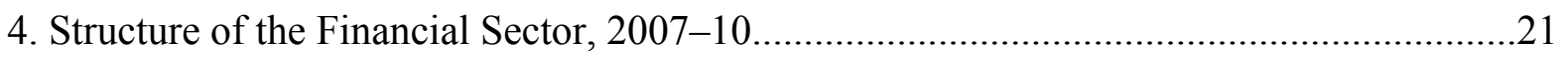

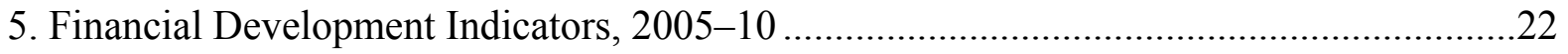

6. Selected Indicators of Financial Health, 2005-10 .....................................................27

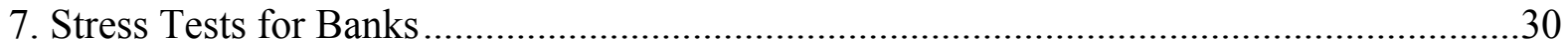

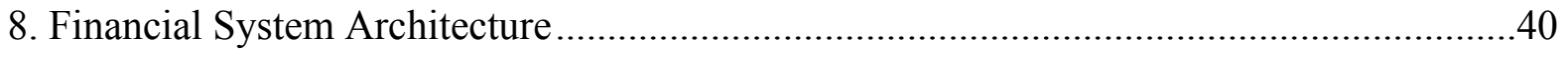




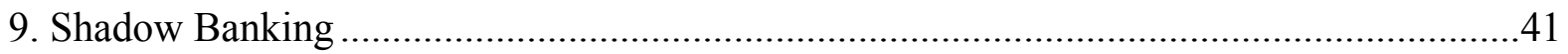

10. Legal and Regulatory Framework for Selected Financial Products ..................................44

11. Insurance — Operating Performance by Size, 2009 .........................................................4

Figures

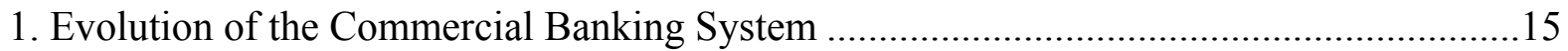

2. Scale of Retail Lending in Selected Banking Systems, 2009 ……..................................15

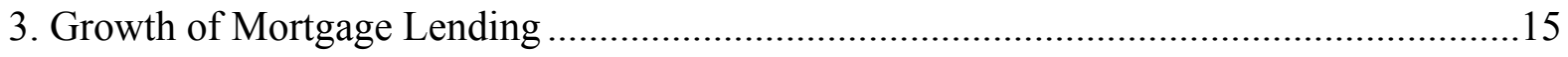

4. Benchmark and Average Lending Rates....................................................................16

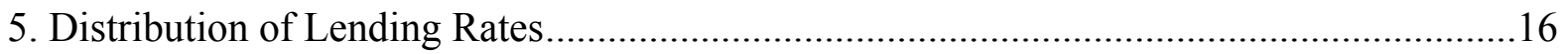

6. Residential Housing Prices and Mortgage Lending..........................................................18

7. Bank Loans to the Real Estate Sector, Year-on-Year Changes ...........................................18

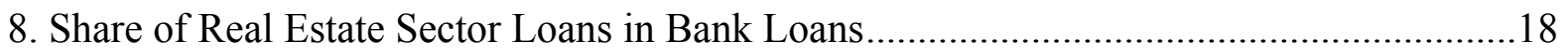

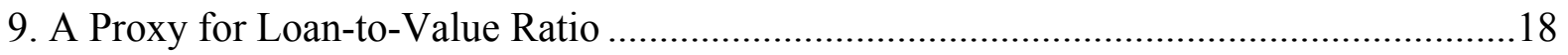

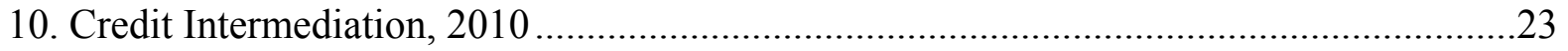

11. Commercial Banking System Structure by Assets, 2010 .............................................23

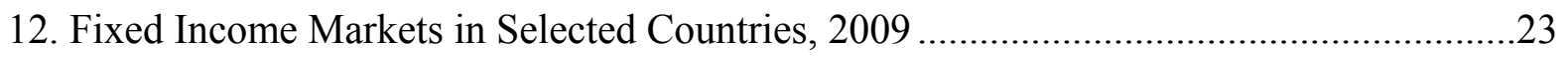

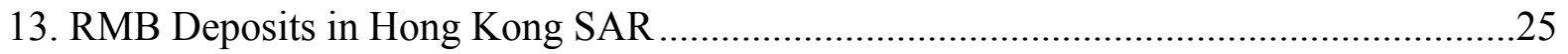

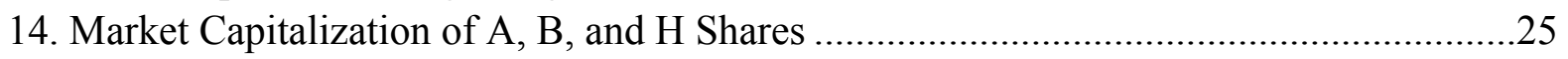

15. Hong Kong SAR Market Premium for Chinese Equity..................................................2

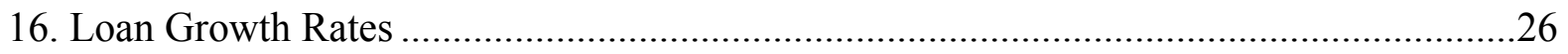

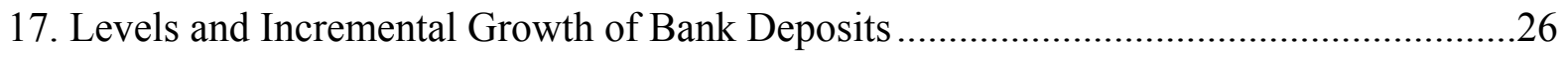

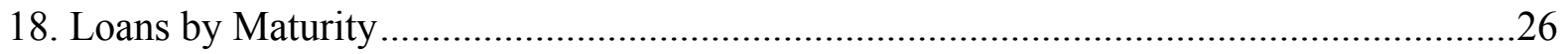

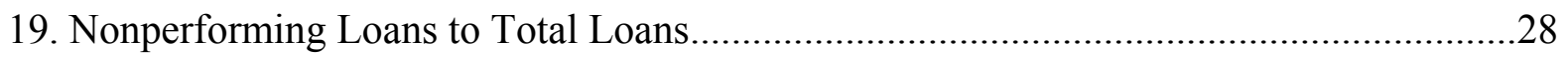

20. Depository Corporations' Foreign Asset and Liability Positions .....................................28

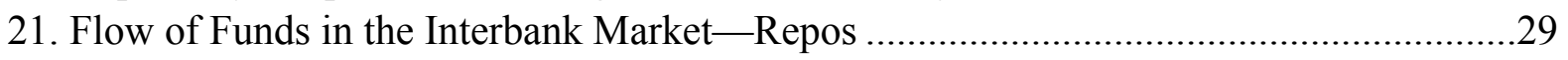

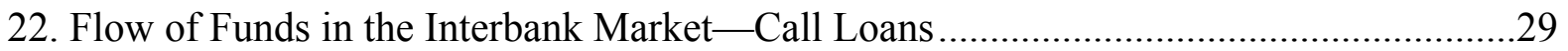

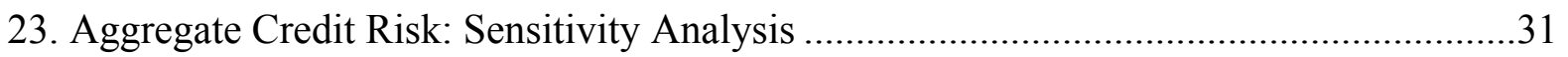

24. Credit Concentration: Real Estate Sensitivity Analysis.....................................................32

25. Change in CAR: Credit Concentration: Real Estate-

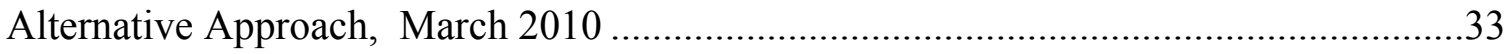

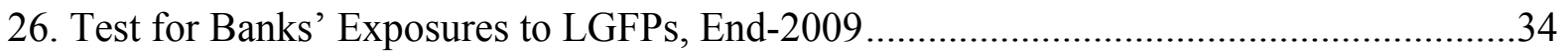

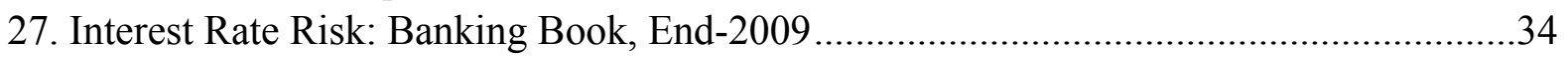

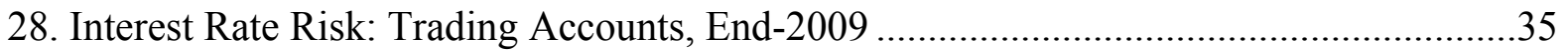

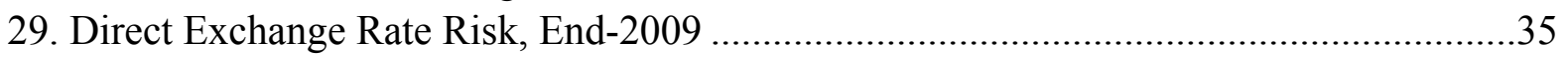

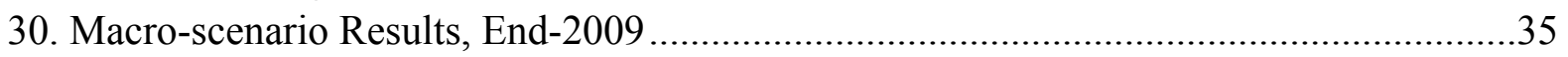

31. Reliance on Real Estate Collateral in Bank Lending, 2007 .............................................43

32. Each Public Sector Debt Issuer Dominates in a Different Maturity Segment....................46

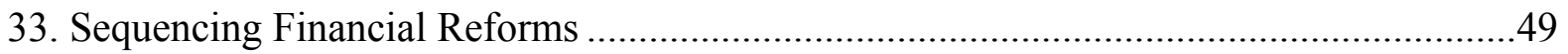

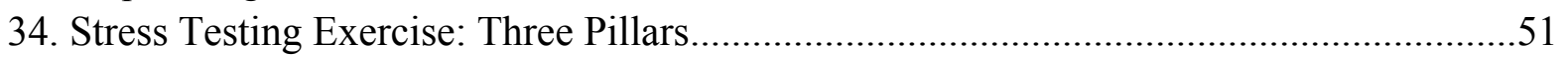

Box

1. Real Estate Sector and Banking Sector Soundness.........................................................17 
Appendix

I. Stress Testing

Appendix Tables

12. Macroeconomic Scenario Assumptions.

13. Recommendations for Improvements in Stress Testing

Annexes

I. Observance of Financial Sector Standards and Codes-Basel Core

Principles for Effective Banking Supervision: A Summary...

II. Observance of Financial Sector Standards and Codes-IAIS Insurance

Core Principles: A Summary

III. Observance of Financial Sector Standards and Codes-IOSCO

Objectives and Principles of Securities Regulation: A Summary

IV. Observance of Financial Sector Standards and Codes-Assessments

of Observance of CPSS Core Principles for Systemically Important

Payment Systems: A Summary

V. Observance of Financial Sector Standards and Codes-Assessment

of Observance of CPSS-IOSCO Recommendatiions for Securities

Settlement Systems and Central Counterparties: A Summary

Annex Tables

14. Summary Compliance with the Basel Core Principles ....

15. Recommended Action Plan to Improve Compliance with the Basel Core Principles

16. Summary of Observance of the Insurance Core Principles

17. Recommended Action Plan to Improve Observance of the Insurance Core Principles

18. Summary of Implementation of the IOSCO Principles-ROSCs

19. Recommended Action Plan to Improve Implementation of the IOSCO Principles

20. Recommended Actions to Improve Observance of CPSS Core Principles and Central Bank Responsibilities in Applying the CPs China HVPS

21. Recommended Actions to Improve Observance of CPSS-IOSCO RSSS-OTC Bonds Market-CCDC

22. Recommended Actions to Improve Observance of CPSS-IOSCO RSSS — Stock Exchange (SSE, SZSE) - SD\&C.

23. Recommended Actions to Improve Observance of CPSS-IOSCO RCCP-SHFE. 


\section{GLOSSARY}

\begin{tabular}{|c|c|}
\hline $\mathrm{ABC}$ & Agricultural Bank of China \\
\hline $\mathrm{ACHs}$ & Automated Clearinghouses \\
\hline AIA & International Assurance Company \\
\hline $\mathrm{AMCs}$ & Asset Management Companies \\
\hline AML/CFT & Anti-Money Laundering/Combating the Financing of Terrorism \\
\hline $\mathrm{BCP}$ & Basel Core Principles for Effective Banking Supervision \\
\hline BEPS & Bulk Electronic Payment System \\
\hline CAR & Capital Adequacy Ratio \\
\hline CBRC & China Banking Regulatory Commission \\
\hline $\mathrm{CCB}$ & China Construction Bank \\
\hline $\mathrm{CCDC}$ & China Central Depositary Trust \& Clearing Co., Ltd. \\
\hline $\mathrm{CCP}$ & Central Counterparty \\
\hline CDB & China Development Bank \\
\hline CFA & China Futures Association \\
\hline CFETS & China Foreign Exchange Trading System \\
\hline CFFEX & China Financial Futures Exchange \\
\hline CIRC & China Insurance Regulatory Commission \\
\hline CIS & Collective Investment Scheme \\
\hline CNAPS & China National Advanced Payment System \\
\hline CNPS & China National Payment System \\
\hline CPA & China's Certified Professional Accountant \\
\hline CPSS & Committee on Payment and Settlement Systems \\
\hline CSD & Central Securities Depository \\
\hline CSRC & China Securities Regulatory Commission \\
\hline CUP & China Union Pay \\
\hline $\mathrm{DaP}$ & Delivery after Payment \\
\hline DCE & Dalian Commodity Exchange \\
\hline FATF & Financial Action Task Force \\
\hline FHCs & Financial Holding Companies \\
\hline FoP & Free of Payment \\
\hline FSAP & Financial Sector Assessment Program \\
\hline GEB & Growth Enterprise Board \\
\hline HVPS & High Value Payment System \\
\hline HQ & Headquarters \\
\hline IAIS & International Association of Insurance Supervisors \\
\hline IASB & International Accounting Standards Board \\
\hline IBBM & Interbank Bond Market \\
\hline ICBC & Industrial Commercial Bank of China \\
\hline ICP & Insurance Core Principles \\
\hline IFRS & International Financial Reporting Standards \\
\hline IMF & International Monetary Fund \\
\hline
\end{tabular}


IT

JSCBs

KRI

LCBs

LCPs

LGFP

MMOU

MOF

MOU

MSE

NAO

NBFI

NDRC

NPS

NPL

$\mathrm{PaD}$

PBC

PICC

$\mathrm{P} \& \mathrm{C}$

QDII

QFII

RCSA

RMB

SAFE

SAC

SD\&C

SHFE

SIPF

SIPS

SME

SOE

SRO

SSE

SSS

SZSE

ZCE
Information Technology

Joint-Stock Commercial Banks (12 banks as of end-2010)

Key Risk Indicators

Large Commercial Banks (Top 5)

Local Processing Centers

Local Government Financing Platform

Multilateral Memorandum of Understanding on Exchange of Information

Ministry of Finance

Memorandum of Understanding

Micro and Small Enterprise

National Audit Office

Nonbank Financial Institution

National Development and Reform Commission

National Payment System

Nonperforming Loan

Payment after Delivery

People's Bank of China

People's Insurance Company of China

Property and Casualty

Qualified Domestic Institutional Investor

Qualified Foreign Institutional Investor

Risk and Control Self Assessment

Renminbi (yuan)

State Administration of Foreign Exchange

Securities Association of China

China Securities Depository and Clearing Corporation Limited

Shanghai Futures Exchange

Securities Investment Protection Fund

Systemically Important Payment System

Small and Medium Enterprise

State-Owned Enterprise

Self-Regulatory Organizations

Shanghai Stock Exchange

Securities Settlement Systems

Shenzhen Stock Exchange

Zhengzhou Commodity Exchange 


\section{EXECUTIVE SUMMARY}

1. China has made remarkable progress in its transition toward a more commercially-oriented and financially sound system. Improvements continue to be made to the structure, performance, transparency, and oversight of financial institutions and markets. As a result, the financial sector entered the global financial crisis from a position of relative strength.

\section{Potential risks}

\section{Despite ongoing reform and financial strength, China confronts a steady build-} up of financial sector vulnerabilities. The system is becoming more complex and interlinkages between markets, institutions, and across international borders are growing. In addition, informal credit markets, conglomerate structures, and off-balance sheet activities are on the rise. Furthermore, the current growth model, the associated and relatively inflexible macroeconomic policy framework, and the government's important role in credit allocation at the central and provincial levels are leading to a build-up of contingent liabilities. These could affect the needed reorientation toward domestic demand and new sectors of growth. These vulnerabilities are not easily quantified, however, in part due to limitations on monitoring, data collection, and inter-agency information exchange.

3. The main near-term domestic risks to the financial system are four-fold: (i) the impact of the recent sharp credit expansion on banks' asset quality; (ii) the rise of off-balance sheet exposures and of lending outside of the formal banking sector; (iii) the relatively high level of real estate prices; and (iv) the increase in imbalances due to the current economic growth pattern.

\section{Jointly conducted stress tests of the largest $\mathbf{1 7}$ commercial banks indicate that} most of the banks appear to be resilient to isolated shocks. Such shocks included a sharp deterioration in asset quality, a correction in the real estate markets, shifts in the yield curve, and changes in the exchange rate. If several of these risks were to occur at the same time, however, the banking system could be severely impacted. A full assessment of the extent of these risks and how they could permeate through the economic and financial system, however, was hindered by data gaps, the lack of sufficiently long and consistent time series of key financial data, weaknesses in the informational infrastructure, and constraints on the FSAP team's access to confidential data.

\section{Reforms to strengthen the monitoring and resolution of risks}

5. Continued advances in supervision and regulation, and the financial stability framework, together with the upgrading of banks' risk management systems are required to effectively respond to these risks. As the range of financial activities offered in China grows, there is a need for a concomitant expansion of the regulatory and supervisory perimeter, combined with stronger supervision of financial groups and robust systemic 
oversight. This will require augmenting resources and skilled personnel, and improved coordination and information and data exchanges among the key agencies. The People's Bank of China (PBC) and the various supervisory commissions must build staff capacity, adopt new risk monitoring systems, strengthen their intervention frameworks, and establish more forward-looking approaches to assessing financial stability conditions. In support of this, continuing improvements in accounting requirements, data standards, reporting requirements, and meaningful disclosure should be an immediate priority.

\section{Institutional reforms will help bring the system more in line with international}

practices. The mandates of the supervisory agencies should focus on ensuring the safety and soundness of regulated institutions, risk management, and proper market conduct and avoid taking on the responsibility for promoting the development of specific economic sectors or for making decisions on how capital should be intermediated and allocated. Ensuring the operational autonomy of the central bank and the financial supervisors is crucial. Implementation of a formalized financial stability framework and mechanisms for contingency planning is essential. Establishing a permanent committee on financial stability and systemic risk that builds on China's recent experience with an ad-hoc committee set up in June 2008, would be a useful step. Chaired by a senior official with authority, the committee should have access to all relevant supervisory and other financial information. Consistent with its financial stability mandate, the PBC should serve as its secretariat.

\section{A framework to resolve weak financial institutions on a timely basis is also} needed. The framework would be designed to facilitate the orderly resolution and winding up of distressed financial institutions. A designated government entity should be vested with resolution powers to address institutions determined to be nonviable by their supervisor. As part of this framework, an explicit deposit insurance scheme presently under consideration should be established promptly to finance the orderly resolution of failed depository institutions and protect insured depositors, while minimizing the cost to the public purse.

Towards a more market-based system

8. In addition, broad policy changes will be needed to safeguard financial stability and to support continued strong and balanced growth. The existing configuration of financial policies fosters high savings, structurally high levels of liquidity, and a high risk of capital misallocation and asset bubbles, particularly in real estate. The cost of these distortions is rising over time, posing increasing macro-financial risks. So far, costs relating to the financial system have been absorbed by rapid productivity gains, and by an implicit tax on households through low remuneration on deposits, but these cannot be presumed to continue. To ensure strong and balanced growth going forward, needed financial system reforms include:

- Improved management of systemic liquidity. The current high levels of foreign exchange intervention, limited exchange rate movements, and strong incentives for 
capital inflows hamper systemic liquidity management and control. Steps to drain large amounts of structural liquidity along with moves towards a liberalized and flexible exchange market will reduce financial stability risks and afford the central bank with greater levers for monetary control.

- $\quad$ Greater use of market-oriented monetary policy instruments. Interest rates should be the primary instrument to govern credit expansion rather than administrative limits on bank lending. This would enhance the efficiency of capital allocation, strengthen the role of monetary policy, and reduce financial stability risks associated with offbalance sheet lending. Interest rate reform needs to be accompanied by strengthened supervision and improved bank risk management and corporate governance.

- Broadening financial markets and services. Developing diversified modalities for financial intermediation would create competitive discipline on the banks, offer enterprises alternative avenues for financing, and provide households with a broader range of financing and investment possibilities. The government must move ahead with its priority to deepen fixed income markets and develop a diversified domestic institutional investor base.

- $\quad$ A reorientation in the role and responsibilities of government. Banks' large exposures to state-owned enterprises, guaranteed margins provided by interest rate regulations, still limited ability and willingness to differentiate loan rates, coupled with the implicit guidance on the pace and direction of new lending, undermine development of effective credit risk management in the banks. It is important that banks have the tools and incentives to make lending decisions based upon purely commercial goals.

- $\quad$ Replacing the use of the commercial banking system to pursue broader policy goals. The use should be made of direct fiscal expenditures and subsidies, direct lending by policy banks, and explicit government-sponsored credit programs for developmental credit. The government must start establishing safeguards and policy reforms that remove distortions and curb those incentives that place risks on the public sector balance sheet as contingent liabilities.

- An upgrading of the financial infrastructure and legal framework. Payments and securities settlement systems have been strengthened, but further progress is required along with continued improvements in the coverage and quality of the Credit Reference Center and oversight of credit rating agencies. As new products are introduced and access is increased, stronger consumer protection, including an expanded financial literacy program, together with improved insolvency proceedings are critical. Cross border and cross currency prudential framework should be strengthened given recent growth in cross-border financial activity and RMB transactions.

9. Given these challenges and build-up of vulnerabilities, calibrating the appropriate pace and order of future reforms will be key. A well-composed and properly 
implemented plan, including the various elements discussed above, will make an important contribution to sustaining China's growth. International experience suggests that ad hoc or partial reforms could themselves pose a risk to financial stability. In the case of China this will be all the more critical given the close association between the macroeconomic policy framework and the financial system. Certain pre-conditions have to be made before broader acceleration of financial deepening, liberalization of interest rates, and, finally, full liberalization of the capital account. Such pre-conditions include putting in place a well functioning legal, regulatory, supervisory, and crisis management framework; improving the corporate governance in banks; early absorption of the current liquidity overhang in the financial system; and greater reliance on market-oriented monetary policy instruments. Therefore, careful planning will be critical to smoothly and safely transition to a more market-based system. To help with this process, a prioritized list of recommendations in key areas is presented in Table 1 along with an assessment of the main risk factors in Table 2 . 


\section{Table 1. China: Key Recommendations}

\begin{tabular}{|c|c|c|}
\hline Recommendations & Priority & $\begin{array}{l}\text { Time- } \\
\text { Frame }\end{array}$ \\
\hline \multicolumn{3}{|l|}{ Improving commercialization } \\
\hline $\begin{array}{l}\text { 1. Continue to advance the process of interest rate and exchange rate reform }(\Phi 8,11,50,51,52,68,79) \text {, } \\
\text { while ensuring that appropriate credit risk management practices in financial institutions are in place. } \\
(\Phi 5,8,11,50,51,57,58,79)\end{array}$ & High & MT \\
\hline $\begin{array}{l}\text { 2. Clearly delineate the roles and functioning of policy financial institutions from commercial financial } \\
\text { institutions. }(\uparrow 6,8,12,15,55)\end{array}$ & Medium & MT \\
\hline $\begin{array}{l}\text { 3. Transform the four Asset Management Companies (AMCs) into commercial entities and, as a first } \\
\text { step, require them to publish periodic financial statements and management reports. ( }(49)\end{array}$ & Medium & MT \\
\hline \multicolumn{3}{|l|}{ Increasing efficiency of the institutional, regulatory, and supervisory framework } \\
\hline $\begin{array}{l}\text { 4. Empower the PBC and three supervisory commissions with focused mandates, operational autonomy } \\
\text { and flexibility, increased resources and skilled personnel, and strengthen interagency coordination to } \\
\text { meet the challenges of a rapidly evolving financial sector. }(₫ 5,6,39,53,54)\end{array}$ & High & MT \\
\hline $\begin{array}{l}\text { 5. Develop a framework for regulation and supervision of financial holding companies (FHCs), } \\
\text { financial conglomerates, and informal financial firms ( }(54) \text {. In the interim, acquisition of a regulated } \\
\text { institution should be approved by the regulatory commission responsible for the underlying financial } \\
\text { institution. ( } ₫ 54)\end{array}$ & Medium & NT \\
\hline $\begin{array}{l}\text { 6. Introduce a more forward-looking assessment of credit risk in the China Banking Regulatory } \\
\text { Commission (CBRC) risk rating system and eliminate deviations from the capital framework for } \\
\text { credit and market risk. ( }(\| 56)\end{array}$ & Medium & NT \\
\hline $\begin{array}{l}\text { 7. Introduce a formal program whereby the China Securities Regulatory Commission (CSRC) conducts } \\
\text { regular comprehensive on-site inspections of the exchanges to improve oversight. ( }(60)\end{array}$ & Medium & NT \\
\hline 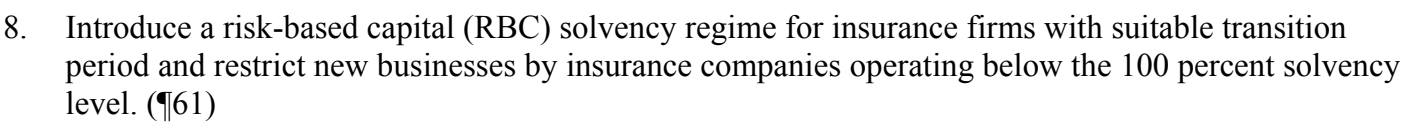 & Medium & MT \\
\hline $\begin{array}{l}\text { 9. Develop explicit and clear regulation for facilitating the exit of insurance companies from the market } \\
\text { via run off or portfolio transfers. ( } \mid 61)\end{array}$ & Medium & NT \\
\hline $\begin{array}{l}\text { 10. Enact a payment system law to give full protection to payments, derivatives and securities settlement } \\
\text { finality. ( } \$ 63)\end{array}$ & Medium & MT \\
\hline $\begin{array}{l}\text { 11. Ensure that beneficial ownership and control information of legal persons is adequate, accurate, and } \\
\text { readily accessible to competent authorities. ( } ₫ 67)\end{array}$ & High & MT \\
\hline $\begin{array}{l}\text { 12. Improve information sharing and coordination arrangements among the PBC and other agencies on } \\
\text { anti-money laundering (AML) and other supervisory issues. }(\$ 39,53,54,67)\end{array}$ & High & MT \\
\hline \multicolumn{3}{|l|}{ Upgrading the framework for financial stability, systemic risk monitoring, systemic liquidity, and crisis management } \\
\hline 13. Establish a permanent committee of financial stability, with the PBC as its secretariat. $(\boldsymbol{\Phi} 6,39)$ & High & MT \\
\hline $\begin{array}{l}\text { 14. Upgrade data collection on financial institutions including their leverage, contingent liabilities, off- } \\
\text { balance sheet positions, unregulated products, and cross-border and sectoral exposures. ( } ₫ 40)\end{array}$ & Medium & NT \\
\hline
\end{tabular}




\begin{tabular}{|c|c|c|}
\hline Recommendations & Priority & $\begin{array}{l}\text { Time- } \\
\text { Frame }\end{array}$ \\
\hline $\begin{array}{l}\text { 15. Build a macro prudential framework for measurement and management of systemic risks; this should } \\
\text { include increasing the resources and capacity of the PBC and regulatory agencies to monitor } \\
\text { financial stability and to carry out regular stress tests. }(\boldsymbol{q} 41)\end{array}$ & High & NT \\
\hline $\begin{array}{l}\text { 16. Enhance the sterilization of structural liquidity through market-based instruments and manage } \\
\text { systemic liquidity spillovers via indirect monetary policy instruments. }(\Phi 42,51)\end{array}$ & High & NT \\
\hline $\begin{array}{l}\text { 17. Introduce reserve averaging to facilitate liquidity management and enhance stability and efficiency. } \\
(\Phi 43)\end{array}$ & High & NT \\
\hline $\begin{array}{l}\text { 18. Start targeting a short-term repo rate on a pilot basis, as a trial of indirect liquidity management, and } \\
\text { commence daily open market operations. }(₫ 44,45)\end{array}$ & High & NT \\
\hline $\begin{array}{l}\text { 19. Ensure that PBC’s standing facilities operate immediately and automatically, with specified } \\
\text { collateral requirement identical across all domestically incorporated institutions. ( } \$ 46)\end{array}$ & Medium & NT \\
\hline $\begin{array}{l}\text { 20. Introduce a deposit insurance scheme to assist in the orderly wind-down of financial institutions and } \\
\text { to help clarify the contingent liability. }(₫ 7,48)\end{array}$ & Medium & NT \\
\hline
\end{tabular}

\section{Developing securities markets and redirecting savings to contractual and collective investment sectors}

21. Ensure regulations are consistent and clarify regulatory responsibilities to support fixed income market development. ( $($ 69)

22. Continue to improve bond issuance strategies between Ministry of Finance (MOF) and PBC to help improve the existing market-making across all maturities of the yield curve. ( $(70)$

23. Upgrade regulatory and operational repo market framework to increase market liquidity, enhance risk management and reinforce the money and bond market interest rate nexus. ( $\mid 68)$

24. Ease the 40 percent of net assets limit applicable to corporation's market based debt issuance to expand their direct funding capacity. ( $(72)$

25. Upgrade links between China Central Depository Trust \& Clearing Co., Ltd (CCDC) and Securities Depository and Clearing Corporation Limited (SD\&C) to enhance connectivity among Interbank Bond Market (IBBM), Shanghai Stock Exchange (SSE), and Shenzhen Stock Exchange (SZSE), support further development, and contribute to efficiency in all three markets. (\$72)

26. Consolidate the multi-pillar pension system, with emphasis on the funded component. (\$75)

\begin{tabular}{|c|c|}
\hline Medium & MT \\
Medium & NT \\
Medium & MT \\
Medium & MT \\
Medium & MT \\
\hline Medium & MT \\
\hline High & MT \\
\hline
\end{tabular}

29. Complete the reform of the Postal Savings Bank (PSB) by optimizing equity ownersh
the bank to become a corporation, and building effective corporate governance. $(\mathbb{\uparrow} 76)$ Notes: NT (Near Term) means implementation completed within three years; MT (Medium Term) means implementation completed in three to five years. 


\section{Table 2. China: Risk Assessment Matrix}

\begin{tabular}{|c|c|c|c|}
\hline & $\begin{array}{l}\text { Principal Sources of } \\
\text { Risk }\end{array}$ & Likelihood of Realization (next three years) & Potential Impact on Macro-Financial Stability \\
\hline & $\begin{array}{l}\text { Growing aggregate credit } \\
\text { risks }\end{array}$ & $\begin{array}{l}\text { Medium to High } \\
\text { Very rapid credit growth-up by } 33 \text { percent in } \\
\text { 2009-raises the risk of credit being directed to less } \\
\text { productive investments. Empirically, there is an inverse } \\
\text { relationship between rapid credit growth and bank asset } \\
\text { quality. } \\
\text { - Under the quantitative lending guidance used in } \\
\text { China banks have limited ability to apply prudent risk } \\
\text { management practices, suggesting potential credit } \\
\text { risks. } \\
\text { - Increasing shift of risks off-balance sheet-for } \\
\text { example via wealth management products } \\
\text { (WMPs)-augment credit risk exposures. }\end{array}$ & $\begin{array}{l}\text { Moderate to Severe } \\
\text { - NPL accumulation would impair banks' profitability and } \\
\text { capital positions. A sizeable decrease of loan collateral } \\
\text { values—which in China predominantly takes the form of } \\
\text { real estate-would amplify potential bank losses. } \\
\text { - A potential shock may be augmented by banks' } \\
\text { previous shifts of credit off-balance sheet, which could } \\
\text { undermine monetary policy effectiveness. } \\
\text { - Stress tests show that the impact of concurrent major } \\
\text { credit shocks (a severe scenario includes a slowdown in } \\
\text { annual GDP growth to } 4 \text { percent) could be sizable, with } \\
25 \text { percent of banking system assets dropping below the } \\
8 \text { percent minimum CAR. }\end{array}$ \\
\hline & $\begin{array}{l}\text { An increase of cross- } \\
\text { border capital inflows, } \\
\text { and a potential flow } \\
\text { reversal }\end{array}$ & $\begin{array}{l}\text { Medium to high } \\
\text { - Capital flows (excluding direct investment) to and from } \\
\text { China are becoming large and more volatile, despite } \\
\text { extensive capital controls. In absolute terms, flows have } \\
\text { averaged about } 1 \frac{1}{2} \text { percent of GDP since } 1998 \text {, } \\
\text { compared to a current account balance and net FDI } \\
\text { flows at 4.7percent and } 1 \frac{1}{2} \text { percent of GDP, respectively. } \\
\text { - Rising RMB appreciation expectations, and to a lesser } \\
\text { degree, higher relative interest rates, suggest potentially } \\
\text { stronger speculative capital inflows. The historical } \\
\text { relationship between inflows and RMB appreciation } \\
\text { expectations embedded in NDFs with a 12-month } \\
\text { maturity-typically the most traded maturity-has been } \\
\text { positive and significant. }\end{array}$ & $\begin{array}{l}\text { Moderate } \\
\text { - Capital flows would affect adversely domestic financial } \\
\text { stability via real estate and equity markets. High real } \\
\text { estate-related bank lending exposures (20 percent of } \\
\text { GDP), and indirect exposures via property collateral, } \\
\text { make banks vulnerable to real estate booms and busts } \\
\text { related to more volatile capital flows. } \\
\text { - Large capital inflows could lead to a rapid credit } \\
\text { expansion. While the link between net flows and bank } \\
\text { lending is weakened by sterilization, international } \\
\text { experience shows that lending booms raise the risk of } \\
\text { sizable asset quality deterioration. } \\
\text { - The closed capital account, albeit admittedly porous, } \\
\text { has a mitigating effect against a capital inflow shock. }\end{array}$ \\
\hline & $\begin{array}{l}\text { Alarge and persistent } \\
\text { increase in international } \\
\text { commodity prices with a } \\
\text { pass-through to domestic } \\
\text { inflation }\end{array}$ & $\begin{array}{l}\text { Medium to High } \\
\text { - While some commodity markets have large spare } \\
\text { capacity buffers, a number of key imports in } \\
\text { China-particularly copper and iron ore-do not, } \\
\text { exacerbating vulnerabilities to price upswings in } \\
\text { international commodity markets. } \\
\text { - Empirical studies suggest that rising commodity } \\
\text { prices could exert a significant pressure on the domestic } \\
\text { economy, in view of the pass-through to domestic } \\
\text { inflation (and possibly monetary policy). }\end{array}$ & $\begin{array}{l}\text { Moderate } \\
\text { - Supply price pressures could affect the domestic } \\
\text { economy via a monetary policy adjustment to counteract } \\
\text { consumer price inflation, resulting in a slowdown of } \\
\text { domestic lending, lower repayment capacity and credit } \\
\text { quality deterioration. } \\
\text { - Borrowing firms without sufficient pricing power would } \\
\text { suffer from lower profit margins, resulting in a potential } \\
\text { upsurge of NPL accumulation; transmission of these } \\
\text { risks could lead to second-round economic effects. }\end{array}$ \\
\hline & $\begin{array}{l}\text { Default of infrastructure } \\
\text { projects supported by } \\
\text { local governments }\end{array}$ & $\begin{array}{l}\text { Medium } \\
\text { - Banks' exposures to local government financing } \\
\text { vehicles increased rapidly as a result of the stimulus. } \\
\text { The very rapid expansion of borrowing for large } \\
\text { infrastructure projects creates sizable risks of NPL } \\
\text { buildup, as some project may not generate sufficient } \\
\text { returns to make loan payments. } \\
\text { - The size of infrastructure-related lending to local } \\
\text { governments is non-trivial. At market estimated RMB } 7.7 \\
\text { trillion as of end-June } 2010 \text {, it is equivalent to } 16 \text { percent } \\
\text { of outstanding loans and } 23 \text { percent of GDP at end- } \\
2009 \text {. }\end{array}$ & $\begin{array}{l}\text { Moderate to Severe } \\
\text { - A sharper-than-anticipated correction in real estate } \\
\text { prices would spill over to local infrastructure projects and } \\
\text { test banking system resilience, given high dependence } \\
\text { on land collateral in LGFP funding. } \\
\text { - Complex fiscal federal relations and potential difficulty } \\
\text { in resolving potential burden-sharing between different } \\
\text { levels of government and the banks could enhance risks. } \\
\text { - Stress test results point to manageable risks related } \\
\text { to local government projects; however, these results } \\
\text { need to be used carefully due to data limitations and } \\
\text { ambiguity, regarding potential central government's } \\
\text { support of local governments. }\end{array}$ \\
\hline
\end{tabular}




\begin{tabular}{|c|c|c|c|}
\hline & $\begin{array}{l}\text { Principal Sources of } \\
\text { Risk }\end{array}$ & Likelihood of Realization (next 3 years) & Potential Impact on Macro-Financial Stability \\
\hline 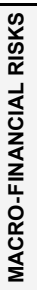 & $\begin{array}{l}\text { A contraction in the global } \\
\text { economy }\end{array}$ & \begin{tabular}{|l|}
\multicolumn{1}{|c|}{ Medium } \\
- In view of China's high dependence on trade and FDI \\
for economic growth, domestic enterprises are exposed \\
to a global macroeconomic shock via the potential \\
negative impact on China's export sector and on \\
industries that depend on FDI flows.
\end{tabular} & $\begin{array}{l}\text { Moderate to Severe } \\
\text { - A global contraction could lead to a weakening of } \\
\text { economic activity and rising unemployment, with an } \\
\text { increase of corporate NPLs and an adverse impact on } \\
\text { banks' solvency. } \\
\text { - Scope for policy response is likely more limited in view } \\
\text { of the already sizable government-led fiscal and monetary } \\
\text { stimulus during the past crisis. }\end{array}$ \\
\hline 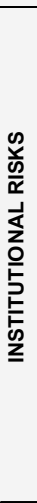 & $\begin{array}{l}\text { Lack of regulation and } \\
\text { supervision on de facto } \\
\text { financial holding } \\
\text { companies and industrial } \\
\text { conglomerates holding } \\
\text { financial institutions }\end{array}$ & $\begin{array}{l}\text { Medium } \\
\text { - Since 2005, with a pilot program of integrated financial } \\
\text { services progressing steadily, de facto financial holding } \\
\text { companies are developing fast. Some industrial } \\
\text { conglomerates are investing in banks, securities firms, } \\
\text { and insurance companies. } \\
\text { - Current regulatory regime has no explicit agency } \\
\text { assigned to oversee the above institutions. The PBC is } \\
\text { taking the lead in drafting administrative rules. } \\
\text { Financial holding companies increased inter linkages } \\
\text { across financial sectors, and industrial conglomerates } \\
\text { holdings could pose risks to both the industrial sector } \\
\text { and financial sector. Lack of effective monitoring and } \\
\text { oversight might trigger systemic risks. }\end{array}$ & $\begin{array}{l}\text { Moderate to Severe } \\
\text { - There are potential contagious risks across different } \\
\text { sectors and markets via cross share holding and } \\
\text { integrated financial services, and may spill over to the } \\
\text { real economy. } \\
\text { - In view of financial holding companies' systemic } \\
\text { importance, failure of financial holding companies could } \\
\text { negatively impact public confidence to the financial } \\
\text { system which could lead to more serious risks. }\end{array}$ \\
\hline 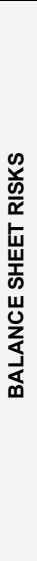 & $\begin{array}{l}\text { A substantial decline in } \\
\text { real estate prices, and an } \\
\text { increase in credit risk } \\
\text { related to property-related } \\
\text { credit, including land }\end{array}$ & $\begin{array}{l}\text { Medium } \\
\text { While real estate prices have risen significantly, } \\
\text { market overheating has been constrained to select Tier } \\
1 \text { cities, with no evidence of systematic nationwide } \\
\text { bubble. } \\
\text { Recent government measures would mitigate the } \\
\text { likelihood of a potential real estate market correction, } \\
\text { with aggregate property prices leveling off and } \\
\text { transaction values declining in recent months. }\end{array}$ & 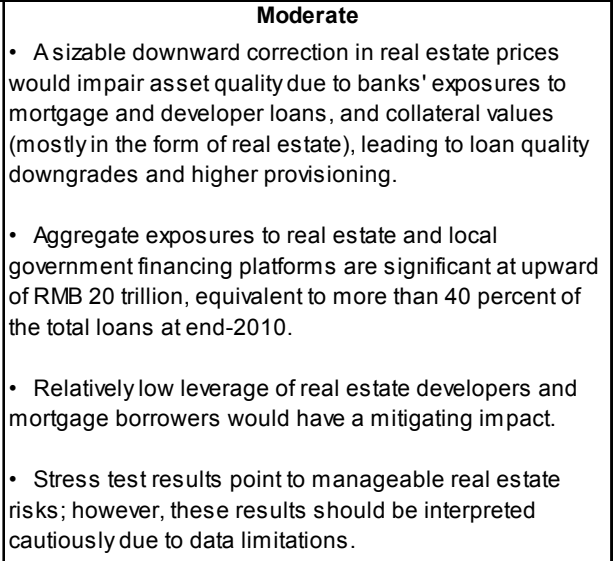 \\
\hline & $\begin{array}{l}\text { A confluence of various } \\
\text { shocks }\end{array}$ & $\begin{array}{l}\text { Low to Medium } \\
\text { Almost all shocks listed in the RAM would trigger } \\
\text { further shocks in view of the linkages across markets } \\
\text { and institutions. }\end{array}$ & $\begin{array}{l}\text { Severe } \\
\text { - For example, significant capital inflows can drive up } \\
\text { equity prices and cause a real estate bubble. This could } \\
\text { have a direct impact on the balance sheets of local } \\
\text { government financing platforms, who are directly } \\
\text { dependent on the real estate market, due to the link of } \\
\text { collateral and capital to land prices. Conversely, a sharp } \\
\text { reversal of capital flows, would lead to sizable downward } \\
\text { corrections in the real estate and equity markets, } \\
\text { impairing banks' asset quality, including a potential } \\
\text { accumulation of local infrastructure-related NPLs. } \\
\text { - Macroeconomic scenario analysis shows that the } \\
\text { system could be severely impacted if several major } \\
\text { shocks materialized concurrently. For example, a severe } \\
\text { scenario (involving a slowdown of GDP growth to } 4 \\
\text { percent year-on-year) implies a system-wide CAR of } \\
\text { about } 8 \text { percent, with banks accounting for some } 1 / 4 \text { of the } \\
\text { total banking system assets falling below the } 8 \text { percent } \\
\text { CAR. }\end{array}$ \\
\hline
\end{tabular}

Source: China FSAP team.

Note: Qualitative assessment is based on ratings of high, medium, or low for likelihood that the vulnerabilities will be exposed by shocks over a three-year horizon. Assessment of the impact on financial stability if the threat is realized is classified with ratings of mild, moderate, and severe. The assessment incorporates stress test results as well as other quantitative and qualitative elements of the FSAP analysis. 


\section{Overall Stability ASSESSMent}

\section{A. The Macro-Financial Environment}

10. China has maintained high growth rates over the past three decades. Since the start of reforms in 1978, growth has averaged close to 10 percent and inflation has remained relatively subdued. Productivity growth has been rapid and capacity has been expanded by very high levels of investment. The commercial banking sector has also grown rapidly and become more diversified (Figure 1). Banks' lending to households, though low compared with other countries, has picked up sharply following the housing sector reform a decade ago (Figures 2 and 3).

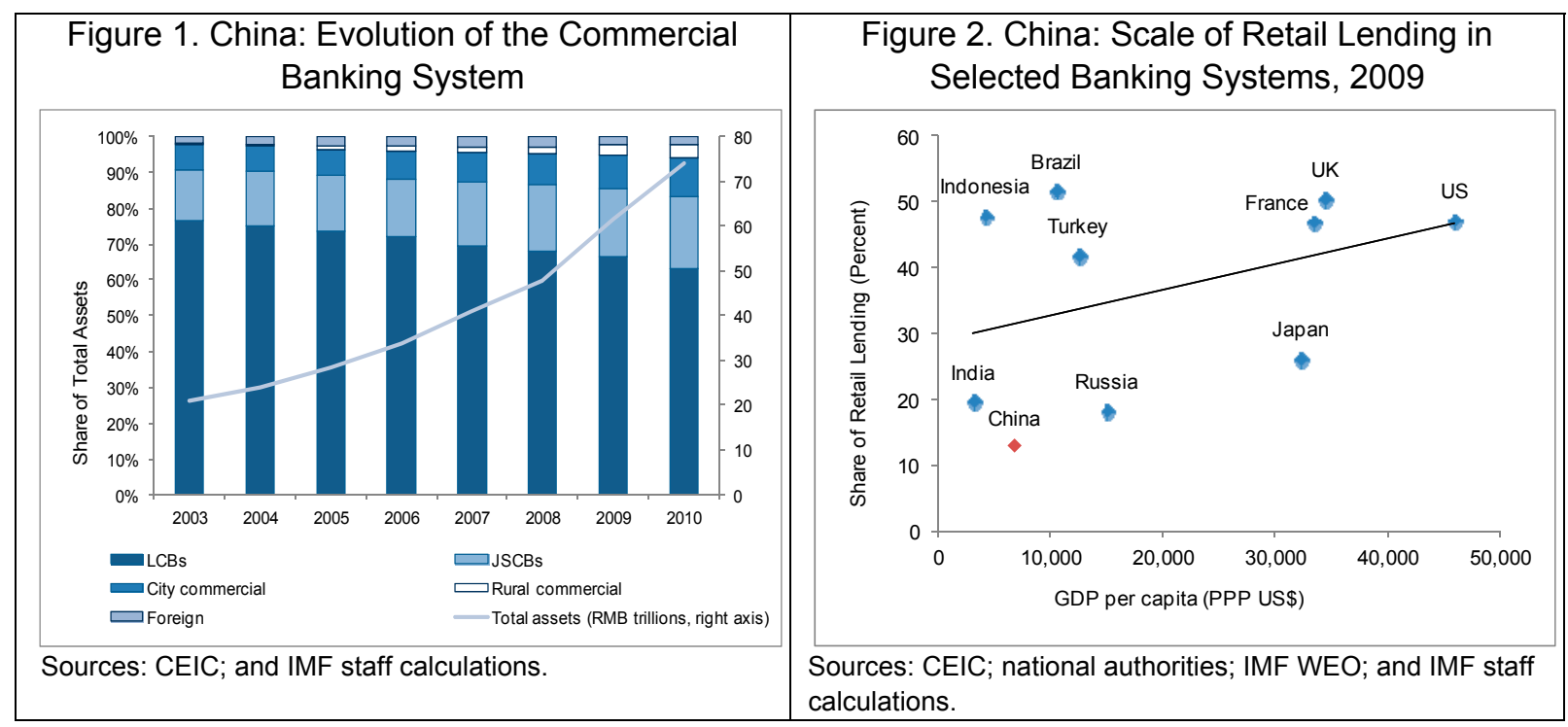

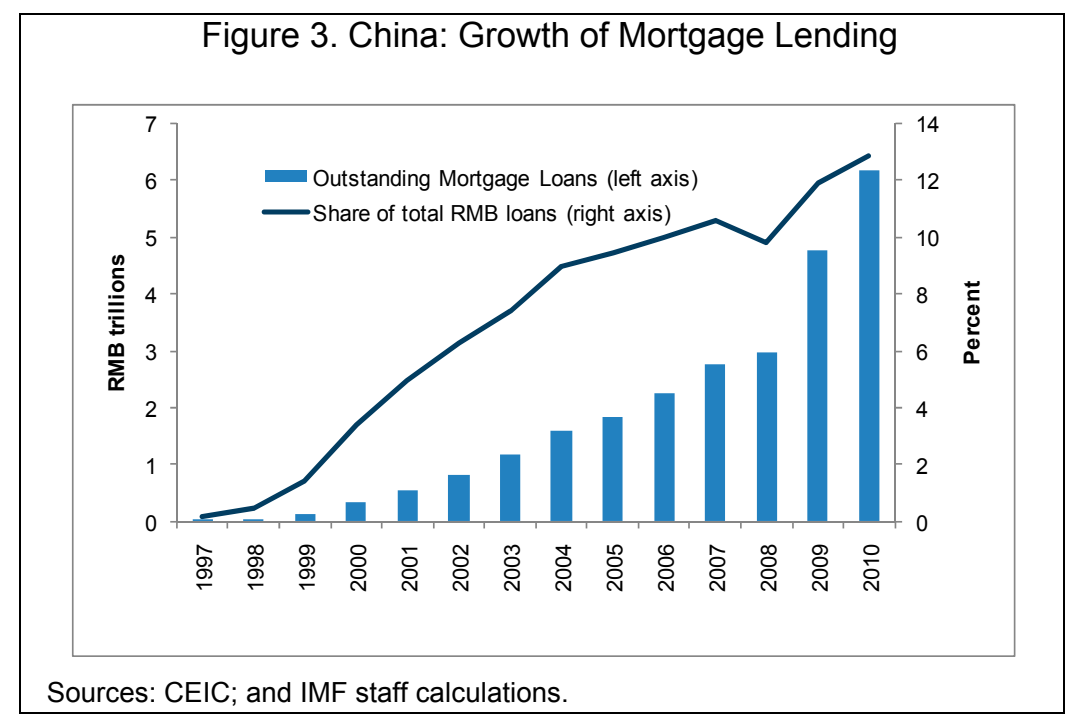


11. The macroeconomic and institutional environment, however, has contributed to credit allocation inefficiencies and a build-up of vulnerabilities:

- First, the relatively low cost of capital distorts saving-investment decisions. The low cost of capital reflects the ceiling on deposit rates and abundant liquidity, lessens foreign exchange sterilization costs, and supports investment and industrialization. It distorts real activity by generating incentives to over-invest and by suppressing household income through low returns on deposits.

- Second, underdeveloped capital markets limit the alternatives for corporate funding and household savings. Households are limited to holding low yielding savings accounts, suppressing income and consumption. The limited availability of insurance products also creates incentives for higher precautionary savings. At the corporate level, lack of access to capital markets by small, private enterprises creates incentives for higher corporate savings. Finally, the search for higher yielding alternative investments by both firms and households adds to the likelihood that asset bubbles may develop, particularly in real estate (Box 1).

- $\quad$ Third, due to incomplete interest rate deregulation and limited exchange rate flexibility, banks and other market participants lack sufficient incentives to improve their assessment, management, and pricing of risks. Banks have some flexibility in setting interest rates on loans, but most lending is clustered around the regulated benchmark loan rate (Figures 4 and 5). Also, the high levels of structural liquidity allow most banks to operate with underdeveloped internal liquidity management processes.

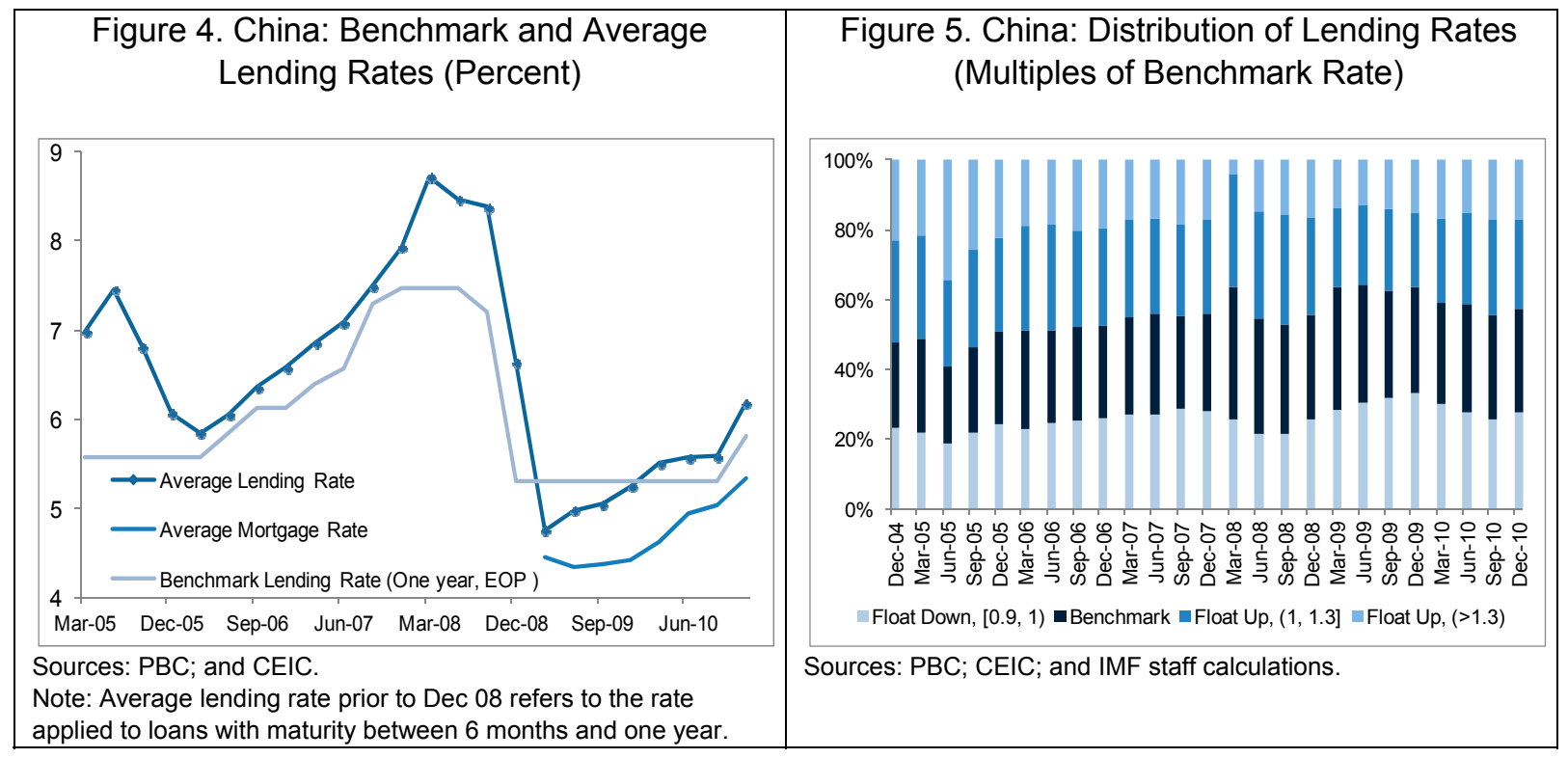




\section{Box 1. Real Estate Sector and Banking Sector Soundness}

The sharp increase in China's real estate prices combined with extraordinarily high bank lending to the real estate sector (Figures 6 and 7) has heightened the prospects of a negative impact of price corrections on China's banking sector. The ongoing tightening measures, however, have slowed down loan growth to the real estate sector and the related price increases. Continuous monitoring, stress test, and a comprehensive set of policies are needed to contain the impact of a real estate price correction on financial stability.

Several fundamental factors are driving the real estate prices in China. These include rapid income growth, low return on deposits, abundant liquidity, lack of alternative investment vehicles, low cost of home ownership, and local governments' reliance on land sales revenues.

The banking sector's direct exposure to the real estate sector is moderate (Figure 8) but the indirect exposure is much higher. Real estate sector related loans account for some 20 percent of the Chinese banking system's total loans, relatively low compared with, for example, Hong Kong SAR or the United States. However, indirect exposure is higher. Loan terms in China depend heavily on collateral use. In the five largest banks, 30-45 percent of loans are backed by collateral, the majority of which is real estate. A large real estate price correction would reduce collateral values, and hence loan recovery value should borrowers default. In addition, credit to industries that are "vertically integrated" with the real estate sector (such as construction, cement, and steel) are also exposed to these risks. Given the importance of the real estate sector for economic growth, an economic slowdown as a result of a real estate price correction could adversely affect the banking system's asset quality. Last but not least, local governments' ability to support local government financing platforms (LGFPs) via land sale and subsidies - essential for those LGFPs with limited cash flows to repay the loans - heavily depends on the real estate market. ${ }^{1}$

In the short-term, the impact appears manageable especially if the current growth momentum continues. There does not appear to be significant over-valuation of residential real estate prices in China as a whole, though there are signs of overvaluation in some market segments. Also, the moderate direct exposure and low leverage ratio (Figure 9) would limit the impact of a real estate price correction on banks' asset quality. Stress testing banks' exposure to the real estate sector alone, or in combination with the "vertically integrated" sectors (Section I. D), suggests a modest impact on banks from credit quality deterioration in the real estate sector. ${ }^{2}$ However, if a growth shock materialized concurrently then the impact on the banking system and its spillovers would be severe.

Over the medium- to long-term, the risk posed by the real estate sector depends on whether the fundamentals behind the real estate price increases are addressed by policy measures. A comprehensive set of measures-including the completion of the interest rate and exchange rate reforms, further capital market development, gradual opening of the capital account, and fiscal reforms, including initiating a broad-based property tax - is needed to promote the orderly development of the real estate market. In the meantime, the authorities should monitor real estate market developments and their potential impact on the banking sector and financial stability, and take prompt corrective steps in case of real estate price overshooting.

'On average, 29 percent of their total revenues were from the sale of land use rights in 2010 (UBS, 2011, "Measuring Property Bubble in China," March 22, 2011). Total revenues include mainly local government revenues, transfer and tax refunds from central government, and land sales revenues.

${ }^{2}$ Due to data issues, the stress testing exercise did not explicitly take into account regional differences in real estate market developments. 


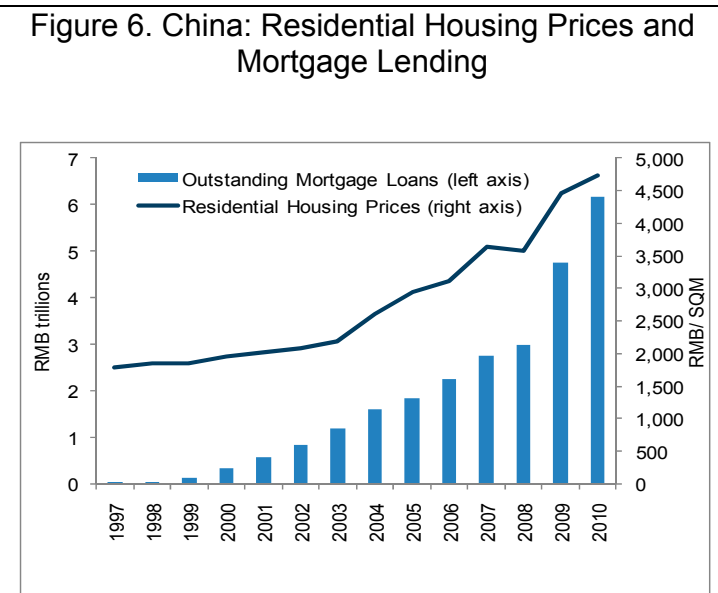

Sources: CEIC; and IMF staff calculations.

Figure 8. China: Share of Real Estate Sector Loans in Bank Loans (Percent)

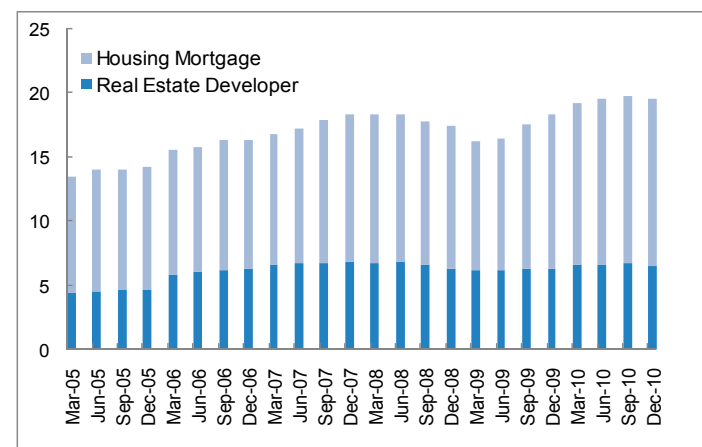

Sources: CEIC; and IMF staff calculations.
Figure 7. China: Bank Loans to the Real Estate Sector, Year-on-Year Changes (Percent)

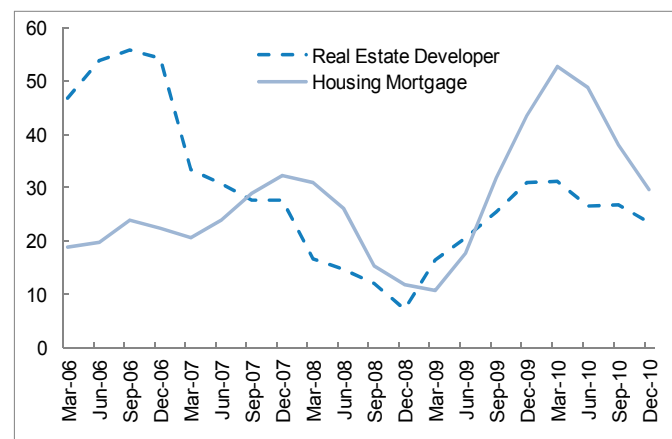

Sources: CEIC; and IMF staff calculations.

Figure 9. China: A Proxy for Loan-to-Value Ratio (Percent)

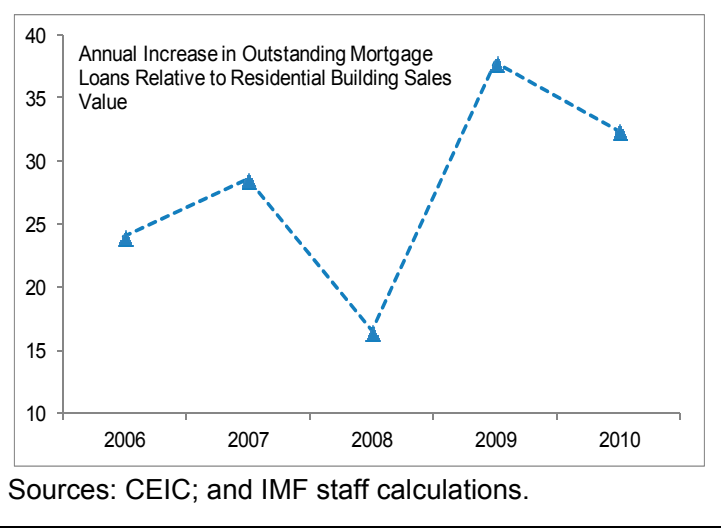

\section{Continued reliance on credit growth targets, even if supplemented by other} policy instruments, undermines the efficiency of credit allocation and disrupts monetary policy transmission. Such credit targets have meant that banks have strong incentives to expand market share to boost interest income and use off-balance sheet channels to circumvent credit targets, compromising monetary control; and that the corporate sector tends to over-borrow, knowing that at some point credit will be rationed. Controlling interest rates and determining quantities of lending also mean that policy makers cannot rely on market prices (such as short-term interest rates) to assess macroeconomic and liquidity conditions.

\section{A by-product of the existing macro-financial and institutional environment is}

low investment efficiency. Since 2001, it is estimated that every US\$ 1 of Chinese GDP growth has required, on average, nearly US\$ 5 of investment, 40 percent more than in Japan and Korea during their take-off periods. ${ }^{1}$ In addition, while the share of China's total savings

\footnotetext{
${ }^{1}$ McKinsey Global Institute, 2006, "Putting China's Capital to Work: The Value of Financial System Reform."
} 
and investment in G-20 aggregates is more than 20 percent, its GDP share is about 10 percent. These may be a reflection of misallocation of capital to some projects with low rates of return.

14. The state is also directly and indirectly involved in the financial sector. A large share of the banking sector is state-owned, as is much of banks' corporate client base. As the principal shareholder, the state appoints senior management in all major banks. In the absence of an explicit deposit insurance system and a resolution framework, the state also implicitly insures all deposits. The heavy involvement by the state in many aspects of the financial system reduces market discipline, weakens corporate governance, and is likely to create soft budget constraints.

\section{Such state involvement has been illustrated by the important role of the banking} system in the conduct of fiscal policy. To counter the impact of the 2008-09 global financial crisis the authorities launched a stimulus package that was implemented through bank credit expansion. Local governments' eagerness to undertake infrastructure projects coupled with revenue-expenditure mismatches and their inability to borrow directly, resulted in a rapid increase in using LGFPs to serve as indirect vehicles to collect bank loans, often using state-owned assets such as land as collateral. As a result, the contingent liabilities of the public sector from such activities increased considerably.

\section{B. Financial System: Structure and Inter-linkages}

\section{China has made progress in moving toward a more commercially-oriented} financial system (Table 3). This has been underpinned by reforms that included recapitalizing the banking system, creating new capital markets, introducing a prudential regulatory regime, opening the financial system following accession to the World Trade Organization, and taking steps to reform interest rate and the exchange rate policies. Reform of the joint-stock banks has boosted the commercial orientation of the banking system and reform of the rural credit cooperatives has yielded some initial results. In the securities sector, key companies have been restructured, and a resolution mechanism and investor protection scheme set up. Pension sector reform has also progressed, with National Social Security Fund established in 2000.

\section{Nonetheless, banks, particularly the largest ones, dominate financial}

intermediation (Tables 4 and 5, and Figure 10). The large commercial banks (LCBs) make up almost two-thirds of commercial bank assets (Figure 11) with the assets of the four largest banks each exceeding 25 percent of GDP. The fixed income market has grown as an alternative funding channel, but remains heavily concentrated in public sector securities (Figure 12). The equity market mainly meets the needs of large enterprises, in spite of recent 


\section{Table 3. China: Financial Sector Reforms-Selected Benchmarks}

19831984 $1992 \quad 1994 \quad 1995 \quad 1996$

PBC mandated as central bank by State Council $\square$ Big 4 banks took over PBC non-central bank function

Policy banks established to take over policy function of Big 4

Central Bank Law and Commercial Bank Law adopted

Four state-owned AMCs set up to dispose NPLs of Big 4 Capital imjection in BOC and $\mathrm{CCB}$ by Huijin Banking sector refo

Legal framework

Market development

Liberalization/international izatio

Capital mjection in ICBC by Huijin

BOC listed on HKSE, ICBC list
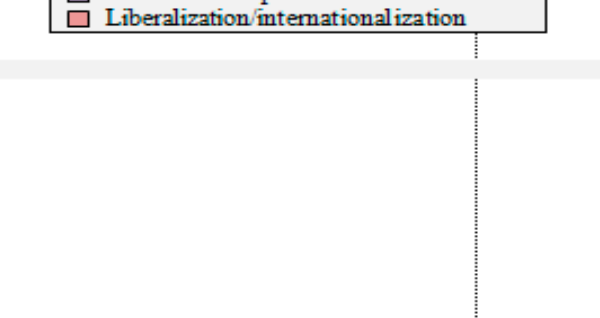

$\square$ CSRC established

Insurance Law adopted (amended in 2009)

Negotiable Instrument Law adopted

$\square$ Securities Law adopted (amended in 2005)

Law on Securities Investment Funds adopted
Revised Enterprise Bankrup

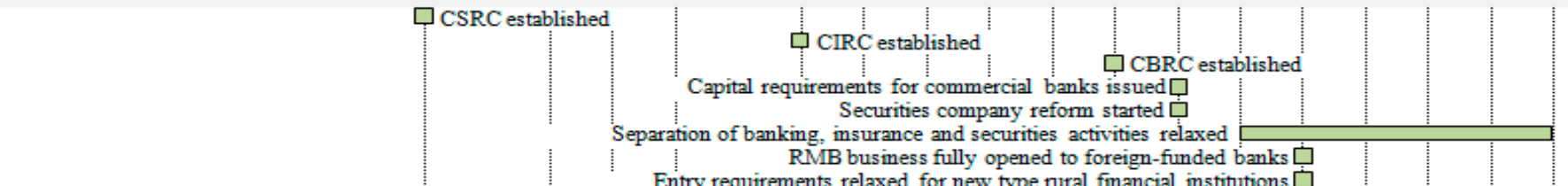

Entry requirements relaxed for new ty

\section{पिCFETS established}

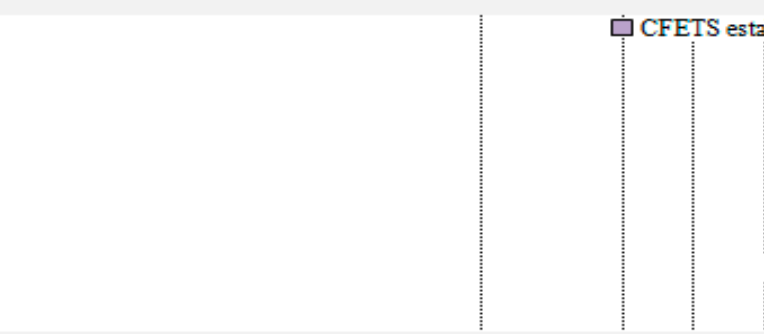

$$
\text { QFII introduced }
$$

SME Board launched on SZSE

Asset-backed securitization pilot started

Non-tradable share reform launched
RMB $\mathrm{F}$.

Interbank FX swaps introduced

PBC Credit Reference Center established

New Accounting Standards for Business Enterprises issued

Growth Enterprise Board launched on SZSE

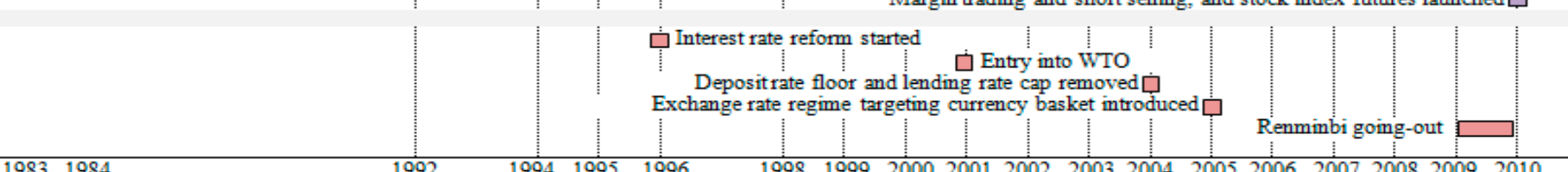

Note: The Big 4 banks are ICBC, $\mathrm{CCB}, \mathrm{ABC}$ and $\mathrm{BOC}$, which have been commercialized in recent years. The Big 4 and Bank of Communications together are referred to as large commercial banks. 
Table 4. China: Structure of the Financial Sector, 2007-10

\begin{tabular}{|c|c|c|c|c|c|c|c|c|c|c|c|c|c|c|c|c|}
\hline & \multicolumn{4}{|c|}{2007} & \multicolumn{4}{|c|}{2008} & \multicolumn{4}{|c|}{2009} & \multicolumn{4}{|c|}{2010} \\
\hline & $\begin{array}{l}\text { Number of } \\
\text { Institutions }\end{array}$ & $\begin{array}{l}\text { Total Assets } \\
\text { (in bln RMB) }\end{array}$ & $\begin{array}{l}\text { Share of Total } \\
\text { Assets }\end{array}$ & Share of GDP & $\begin{array}{l}\text { Number of } \\
\text { Institutions }\end{array}$ & $\begin{array}{l}\text { Total Assets } \\
\text { (in bin RMB) }\end{array}$ & $\begin{array}{l}\text { Share of Total } \\
\text { Assets }\end{array}$ & Share of GDP & $\begin{array}{l}\text { Number of } \\
\text { Institutions }\end{array}$ & $\begin{array}{l}\text { Total Assets } \\
\text { (in bln RMB) }\end{array}$ & $\begin{array}{c}\text { Share of Total } \\
\text { Assets }\end{array}$ & Share of GDP & $\begin{array}{l}\text { Number of } \\
\text { Institutions }\end{array}$ & $\begin{array}{l}\text { Total Assets } \\
\text { (in bln RMB) }\end{array}$ & $\begin{array}{l}\text { Share of Total } \\
\text { Assets }\end{array}$ & Share of GDP \\
\hline Banking Institutions & 8,721 & 51,627 & 84.1 & 194.2 & 5,578 & 61,982 & 87.8 & 197.4 & 3,767 & 77,978 & 87.0 & 229.0 & 3,639 & 93,215 & 87.6 & 234.2 \\
\hline Commercial banks & 187 & 40,459 & 65.9 & 152.2 & 323 & 47,819 & 67.8 & 152.3 & 336 & 61,513 & 68.6 & 180.7 & 379 & 74,160 & 69.7 & 186.3 \\
\hline Large commercial banks & 5 & 28,007 & 45.6 & 105.4 & 5 & 32,575 & 46.2 & 103.7 & 5 & 40,800 & 45.5 & 119.8 & 5 & 46,894 & 44.1 & 117.8 \\
\hline Joint-stock commercial banks & 12 & 7,249 & 11.8 & 27.3 & 12 & 8,834 & 12.5 & 28.1 & 12 & 11,818 & 13.2 & 34.7 & 12 & 14,904 & 14.0 & 37.4 \\
\hline City commercial banks & 124 & 3,340 & 5.4 & 12.6 & 136 & 4,136 & 5.9 & 13.2 & 143 & 5,680 & 6.3 & 16.7 & 147 & 7,853 & 7.4 & 19.7 \\
\hline Rural commercial banks & 17 & 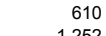 & 1.0 & 2.3 & 22 & 929 & 1.3 & 3.0 & 43 & 1,866 & 2.1 & 5.5 & 85 & 2,767 & 2.6 & 7.0 \\
\hline Foreign banks & 29 & 1,252 & 2.0 & 4.7 & 148 & 1,345 & 1.9 & 4.3 & 133 & 1,349 & 1.5 & 4.0 & 130 & 1,742 & 1.6 & 4.4 \\
\hline Locally incorporated foreign subsidiaries & $\ldots$ & & $\ldots$ & & 32 & 996 & 1.4 & 3.2 & 38 & 1,132 & 1.3 & 3.3 & 40 & 1,522 & 1.4 & 3.8 \\
\hline Branches of foreign banks & & & & & 116 & 349 & 0.5 & 1.1 & 95 & 217 & 0.2 & 0.6 & 90 & 220 & 0.2 & 0.6 \\
\hline Policy banks and China Development Bank & 3 & 4,278 & 7.0 & 16.1 & 3 & 5,645 & 8.0 & 18.0 & 3 & 6,946 & 7.7 & 20.4 & 3 & 7,652 & 7.2 & 19.2 \\
\hline China Postal Savings Bank & 1 & 1,769 & 2.9 & 6.7 & 1 & 2,216 & 3.1 & 7.1 & 1 & 2,705 & 3.0 & 7.9 & 1 & 3,397 & 3.2 & 8.5 \\
\hline Cooperative financial institutions & 8,503 & 5,121 & 8.3 & 19.3 & 5,150 & 6,295 & 8.9 & 20.0 & 3,263 & 6,789 & 7.6 & 19.9 & 2,870 & 7,893 & 7.4 & 19.8 \\
\hline Rural cooperative banks & 113 & 646 & 1.1 & 2.4 & 163 & 1,003 & 1.4 & 3.2 & 196 & 1,270 & 1.4 & 3.7 & 223 & 1,500 & 1.4 & 3.8 \\
\hline Urban credit cooperatives $1 /$ & 42 & 131 & 0.2 & 0.5 & 22 & 80 & 0.1 & 0.3 & 11 & 27 & 0.0 & 0.1 & 1 & 2 & 0.0 & 0.0 \\
\hline $\begin{array}{l}\text { Rural credit cooperatives } 1 / \\
\text { / }\end{array}$ & 8,348 & 4,343 & 7.1 & 16.3 & 4,965 & 5,211 & 7.4 & 16.6 & 3,056 & 5,493 & 6.1 & 16.1 & 2,646 & 6,391 & 6.0 & 16.1 \\
\hline $\begin{array}{l}\text { New-type rural financial institutions } \\
\text { Village or township banks }\end{array}$ & $\begin{array}{l}27 \\
19\end{array}$ & $\begin{array}{l}0 \\
0\end{array}$ & $\begin{array}{l}0 \\
0\end{array}$ & $\begin{array}{l}0 \\
0\end{array}$ & $\begin{array}{r}101 \\
91\end{array}$ & $\begin{array}{l}6 \\
6\end{array}$ & $\begin{array}{l}0 \\
0 \\
0\end{array}$ & $\begin{array}{l}0 \\
0\end{array}$ & $\begin{array}{l}164 \\
148\end{array}$ & $\begin{array}{l}25 \\
25\end{array}$ & $\begin{array}{l}0 \\
0 \\
0\end{array}$ & 0.1 & $\begin{array}{l}386 \\
349\end{array}$ & 113 & 0 & 0.3 \\
\hline $\begin{array}{l}\text { Village or township banks } \\
\text { Rural mutual credit cooperatives }\end{array}$ & $\begin{array}{r}19 \\
8\end{array}$ & 0 & 0 & 0 & $\begin{array}{l}91 \\
10\end{array}$ & $\begin{array}{l}6 \\
0\end{array}$ & $\begin{array}{l}0 \\
0\end{array}$ & $\begin{array}{l}0 \\
0\end{array}$ & $\begin{array}{r}148 \\
16\end{array}$ & $\begin{array}{r}25 \\
0\end{array}$ & $\begin{array}{l}0 \\
0\end{array}$ & $\begin{array}{r}0.1 \\
0\end{array}$ & $\begin{array}{r}349 \\
37\end{array}$ & $\begin{array}{r}113 \\
0\end{array}$ & $\begin{array}{l}0 \\
0\end{array}$ & $\begin{array}{r}0.3 \\
0\end{array}$ \\
\hline Non-Bank Financial Institutions & 690 & 9,744 & 15.9 & 36.7 & 738 & 8,582 & 12.2 & 27.3 & 772 & 11,666 & 13.0 & 34.3 & 782 & 13,168 & 12.4 & 33.1 \\
\hline Insurance companies & 102 & 2,831 & 4.6 & 10.6 & 112 & 3,280 & 4.6 & 10.4 & 120 & 3,971 & 4.4 & 11.7 & 125 & 4,965 & 4.7 & 12.5 \\
\hline Life & 54 & 2,351 & 3.8 & 8.8 & 56 & 2,713 & 3.8 & 8.6 & 59 & 3,366 & 3.8 & 9.9 & 61 & 4,267 & 4.0 & 10.7 \\
\hline Re-insurance ${ }^{1 /}$ & 6 & 89 & 0.1 & 0.3 & 9 & 101 & 0.1 & 0.3 & 9 & 116 & 0.1 & 0.3 & 9 & 115 & 0.1 & 0.3 \\
\hline Non-life & 42 & 391 & 0.6 & 1.5 & 47 & 466 & 0.7 & 1.5 & 52 & 489 & 0.5 & 1.4 & 55 & 584 & 0.5 & 1.5 \\
\hline Pension funds & 39 & 592 & 1.0 & 2.2 & 39 & 754 & 1.1 & 2.4 & 39 & 1,030 & 1.1 & 3.0 & 1 & 1,138 & 1.1 & 2.9 \\
\hline National Social Security Fund & 1 & 440 & 0.7 & 1.7 & 1 & 562 & 0.8 & 1.8 & 1 & 777 & 0.9 & 2.3 & 1 & 857 & 0.8 & 2.2 \\
\hline Enterprise annuities & 38 & 152 & 0.2 & 0.6 & 38 & 191 & 0.3 & 0.6 & 38 & 253 & 0.3 & 0.7 & & 281 & 0.3 & 0.7 \\
\hline Fund management companies & 59 & 3,280 & 5.3 & 12.3 & 61 & 1,939 & 2.7 & 6.2 & 60 & 2,677 & 3.0 & 7.9 & 63 & 2,520 & 2.4 & 6.3 \\
\hline Securities investment funds ${ }^{2 /}$ & 346 & 3,280 & 5.3 & 12.3 & 439 & 1,939 & 2.7 & 6.2 & 577 & 2,677 & 3.0 & 7.9 & 704 & 2,520 & 2.4 & 6.3 \\
\hline Securities firms & 106 & 1,734 & 2.8 & 6.5 & 107 & 1,191 & 1.7 & 3.8 & 106 & 2,027 & 2.3 & 6.0 & 106 & 1,967 & 1.8 & 4.9 \\
\hline Futures companies & 177 & 50 & 0.1 & 0.2 & 171 & 59 & 0.1 & 0.2 & 167 & 121 & 0.1 & 0.4 & 164 & 192 & 0.2 & 0.5 \\
\hline Qualified Foreign Institutional Investors & 51 & 286 & 0.5 & 1.1 & 76 & 179 & 0.3 & 0.6 & 94 & 290 & 0.3 & 0.9 & 106 & 297 & 0.3 & 0.7 \\
\hline Other non-bank financial institutions & 152 & 972 & 1.6 & 3.7 & 168 & 1,181 & 1.7 & 3.8 & 182 & 1,550 & 1.7 & 4.6 & 213 & 2,089 & 2.0 & 5.2 \\
\hline Finance companies of enterprise groups & 73 & . & $\ldots$ & 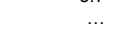 & 84 & 975 & 1.4 & 3.1 & 91 & 1,229 & 1.4 & 3.6 & 107 & 1,541 & 1.4 & 3.9 \\
\hline Trust companies & 54 & $\ldots$ & $\ldots$ & $\ldots$ & 54 & 87 & 0.1 & 0.3 & 58 & 113 & 0.1 & 0.3 & 63 & 148 & 0.1 & 0.4 \\
\hline companies & 10 & & $\ldots$ & & 12 & 80 & 0.1 & 0.3 & 12 & 160 & 0.2 & 0.5 & 17 & 316 & 0.3 & 0.8 \\
\hline e firms & 2 & $\ldots$ & $\ldots$ & $\ldots$ & 3 & 0.1 & 0.0 & 0.0 & 3 & 0.2 & 0.0 & 0.0 & 4 & 0.3 & 0.0 & 0.0 \\
\hline Finance & 13 & $\ldots$ & $\ldots$ & $\ldots$ & 15 & 38 & 0.1 & 0.1 & 18 & 48 & 0.1 & 0.1 & 22 & 84 & 0.1 & 0.2 \\
\hline Lendin & 4 & $\ldots$ & $\cdots$ & $\cdots$ & 6 & 0 & 0 & 0 & 8 & 0 & 0 & 0 & 9 & 0.1 & 0.0 & 0 \\
\hline Auto financing companies & 9 & $\cdots$ & $\cdots$ & $\cdots$ & 9 & 38 & 0.1 & 0.1 & 10 & 48 & 0.1 & 0.1 & 13 & 84 & 0.1 & 0.2 \\
\hline Banking asset management companies ${ }^{3 /}$ & 4 & $\cdots$ & $\ldots$ & $\cdots$ & 4 & $\cdots$ & $\ldots$ & $\ldots$ & 4 & $\cdots$ & 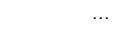 & $\cdots$ & 4 & $\ldots$ & .. & \\
\hline Total Financial System ${ }^{4}$ & 9,411 & 61,370 & 100.0 & 230.9 & 6,316 & 70,564 & 100.0 & 224.7 & 4,539 & 89,644 & 100.0 & 263.3 & 4,421 & 106,383 & 100.0 & 267.3 \\
\hline
\end{tabular}

Sources: PBC; CBRC; CIRC; CSRC; NBS of China; and Ministry of Human Resource and Social Security; and IMF staff calculations.

As there is no insurance company engaged in both life and non-life business, data of reinsurance companies are provided instead. In 2007 the insurance sector adopted new accounting principles which are

applied to the data starting from 2007.
${ }_{2}^{2}$ Proceeds raised by securities investment funds are managed by fund management companies on behalf of fund unit holders.

${ }^{3}$ The table excludes assets of the four AMCs. According to the FSAP team's calculations, the book value of the non-performing assets transferred to the AMCs amounted to about RMB2.6 trillion as of end 2006 (about 6 percent of total financial system assets or 12 percent of GDP). Comparable data for 2007-10 are not available, as the AMCs have not released financial statements since 2006.

This table does not include informal finance, the estimates of which vary.

Notes: Data for 2008, 2009, and 2010 were provided by the Chinese authorities in the context of the FSAP. Data for 2007 were collected from publically available sources, particularly the annual reports of the three financial regulatory commissions and the financial statements of the NSSF. Data on rural and urban credit cooperatives were collected from the CBRC's annual reports 
Table 5. China: Financial Development Indicators, 2005-10

\begin{tabular}{|c|c|c|c|c|c|c|}
\hline & 2005 & 2006 & 2007 & 2008 & 2009 & 2010 \\
\hline \multicolumn{7}{|l|}{ Banking } \\
\hline Total number of banking institutions & - & 19,667 & 8,721 & 5,578 & 3,767 & 3,639 \\
\hline Number of branches/million population & - & 140 & 144 & 146 & 145 & 146 \\
\hline Bank deposits/GDP (\%) & 147.2 & 153.3 & 143.5 & 147.5 & 169.6 & 171.3 \\
\hline Private credit $/$ GDP (\%) & 114.3 & 113.0 & 111.0 & 108.3 & 129.3 & 131.1 \\
\hline Bank assets/total financial system assets (\%) & - & - & 84.1 & 87.8 & 87.0 & 87.6 \\
\hline Bank assets/GDP (\%) & 197.1 & 198.3 & 194.2 & 197.4 & 229.0 & 234.2 \\
\hline \multicolumn{7}{|l|}{ Insurance } \\
\hline Number of life insurers & 42 & 48 & 54 & 56 & 59 & 61 \\
\hline Number of non-life insurers & 35 & 38 & 42 & 47 & 52 & 55 \\
\hline \multicolumn{7}{|l|}{ Insurance Penetration (premiums in \% of GDP) } \\
\hline Life & 1.8 & 1.7 & 1.8 & 2.2 & 2.3 & - \\
\hline Non-life & 0.9 & 1.0 & 1.1 & 1.0 & 1.1 & - \\
\hline \multicolumn{7}{|l|}{ Insurance Density (premiums per capita, RMB) } \\
\hline Life & 250 & 272 & 336 & 498 & 554 & - \\
\hline Non-life & 129 & 155 & 194 & 234 & 273 & - \\
\hline \multicolumn{7}{|l|}{ Pension } \\
\hline Percentage of labor force covered by pensions & 30.1 & 31.5 & 32.8 & 35.4 & 41.2 & $45.7^{2}$ \\
\hline Pension fund assets/GDP (\%) & 1.5 & 1.7 & 2.2 & 2.4 & 3.0 & 2.9 \\
\hline Pension fund assets/total financial system assets (\%) & - & - & - & 1.1 & 1.1 & 1.1 \\
\hline \multicolumn{7}{|l|}{ Mortgage } \\
\hline Mortgage assets/total financial system assets (\%) & - & - & - & 4.2 & 5.0 & 5.2 \\
\hline Mortgage debt stock/GDP (\%) & - & - & - & 9.4 & 13.1 & 14.0 \\
\hline \multicolumn{7}{|l|}{ Money markets } \\
\hline Interbank lending (RMB billion) & 1,278 & 2,150 & 10,647 & 15,049 & 19,350 & 27,868 \\
\hline Pledged repo value of transactions (RMB billion) & 15,678 & 26,302 & 44,067 & 56,383 & 67,701 & 84,653 \\
\hline Outright repo value of transactions (RMB billion) & 219 & 292 & 726 & 1,758 & 2,602 & 2,940 \\
\hline Central bank bill value traded (RMB billion) & 2,893 & 4,240 & 8,704 & 22,827 & 14,213 & 17,465 \\
\hline \multicolumn{7}{|l|}{ Foreign exchange markets } \\
\hline Foreign exchange reserves in months of imports & 13.3 & 14.4 & 16.8 & 18.1 & 24.6 & \\
\hline Foreign exchange reserves/short-term debt & 4.8 & 5.4 & 6.5 & 8.6 & 9.3 & 7.6 \\
\hline Value of transactions in FX swap (USD billion) & 0 & 51 & 315 & 441 & 806 & 1,296 \\
\hline Value of transactions in FX forward (USD billion) & 2.7 & 14.1 & 22.6 & 17.9 & 11.7 & 36.4 \\
\hline \multicolumn{7}{|l|}{ Capital Markets } \\
\hline \multicolumn{7}{|l|}{ Equity market } \\
\hline Number of listed companies & 1,381 & 1,434 & 1,550 & 1,625 & 1,718 & 2,063 \\
\hline Market capitalization of listed companies ${ }^{3} / \mathrm{GDP}(\%)$ & 17.5 & 41.3 & 123.1 & 38.6 & 71.6 & 66.7 \\
\hline Stock market value traded/market capitalization ${ }^{3}(\%)$ & 96.4 & 100.4 & 140.8 & 220.1 & 219.7 & 205.6 \\
\hline Number of new offers & 15 & 66 & 124 & 76 & 99 & 347 \\
\hline Value of new offers (RMB billion) & 5.8 & 134.2 & 481.0 & 103.4 & 187.9 & 488.3 \\
\hline \multicolumn{7}{|l|}{ Bond market } \\
\hline Government bonds outstanding ${ }^{4} /$ GDP (\%) & 27.3 & 28.9 & 32.4 & 31.3 & 29.3 & 28.1 \\
\hline Financial bonds outstanding/GDP (\%) & 10.8 & 12.1 & 12.7 & 13.4 & 15.1 & 15.0 \\
\hline Corporate bonds outstanding/GDP (\%) & 1.7 & 2.6 & 3.0 & 4.1 & 7.1 & 8.6 \\
\hline \multicolumn{7}{|l|}{ Derivatives market } \\
\hline Total market value of warrants traded on SSE and SZSE (RMB billion) & - & - & 54.0 & 17.5 & 20.9 & 1.5 \\
\hline Annual turnover of warrants on SSE and SZSE (RMB billion) & - & - & 7,783 & 6,969 & 5,365 & 1,499 \\
\hline Annual turnover of commodity futures (RMB trillion) & - & - & 20.5 & 36.0 & 65.3 & 113.5 \\
\hline $\begin{array}{l}\text { Total notional outstanding of RMB interest rate derivatives }{ }^{5} \text { (RMB } \\
\text { billion) }\end{array}$ & 5.0 & 33.3 & 217 & 529 & 662 & 1,486 \\
\hline $\begin{array}{l}\text { Average daily trading volume of RMB interest rate derivatives (RMB } \\
\text { billion) }\end{array}$ & 0.0 & 0.1 & 0.9 & 2.1 & 1.9 & 6.0 \\
\hline \multicolumn{7}{|l|}{ Collective investment funds } \\
\hline Number of licensed investment funds & - & - & 346 & 439 & 557 & 704 \\
\hline Number of fund management companies & - & - & 59 & 61 & 60 & 63 \\
\hline Total assets under management by investment funds/GDP (\%) & - & - & 12.3 & 6.2 & 7.9 & 6.3 \\
\hline Share of retail investors in investment funds (\%) & - & - & 89 & 81 & 82 & 82 \\
\hline \multicolumn{7}{|l|}{ Memo: } \\
\hline Nominal GDP (RMB billion) & 18,494 & 21,631 & 26,581 & 31,405 & 34,051 & 39,798 \\
\hline Population (million) & 1,304 & 1,311 & 1,318 & 1,325 & 1,331 & 1,338 \\
\hline
\end{tabular}
Sources: PBC; CBRC; CIRC; CSRC; MOHRSS; CFETS; BIS; IFS; WDI; Swiss Re Sigma; and ChinaBond.com.cn.

${ }^{1}$ Including credit to public enterprises.

${ }^{2}$ Labor force data for 2010 is an estimate.

${ }^{3}$ Including all the A and B shares of companies listed on SSE and SZSE.

${ }^{4}$ Data for government bonds are from the BIS and include both treasury securities and central bank bills/notes.

${ }^{5}$ Estimates by CFETS. 
progress in establishing a multilayer equity market to facilitate funding to SMEs. Assets under management by the insurance sector corresponded to less than 11 percent of household bank deposits. Trust, financial leasing, and finance companies have all been growing rapidly but remain small relative to banks. China also has a flourishing informal financial sector, parts of which provide funding to SMEs and small retail investors.
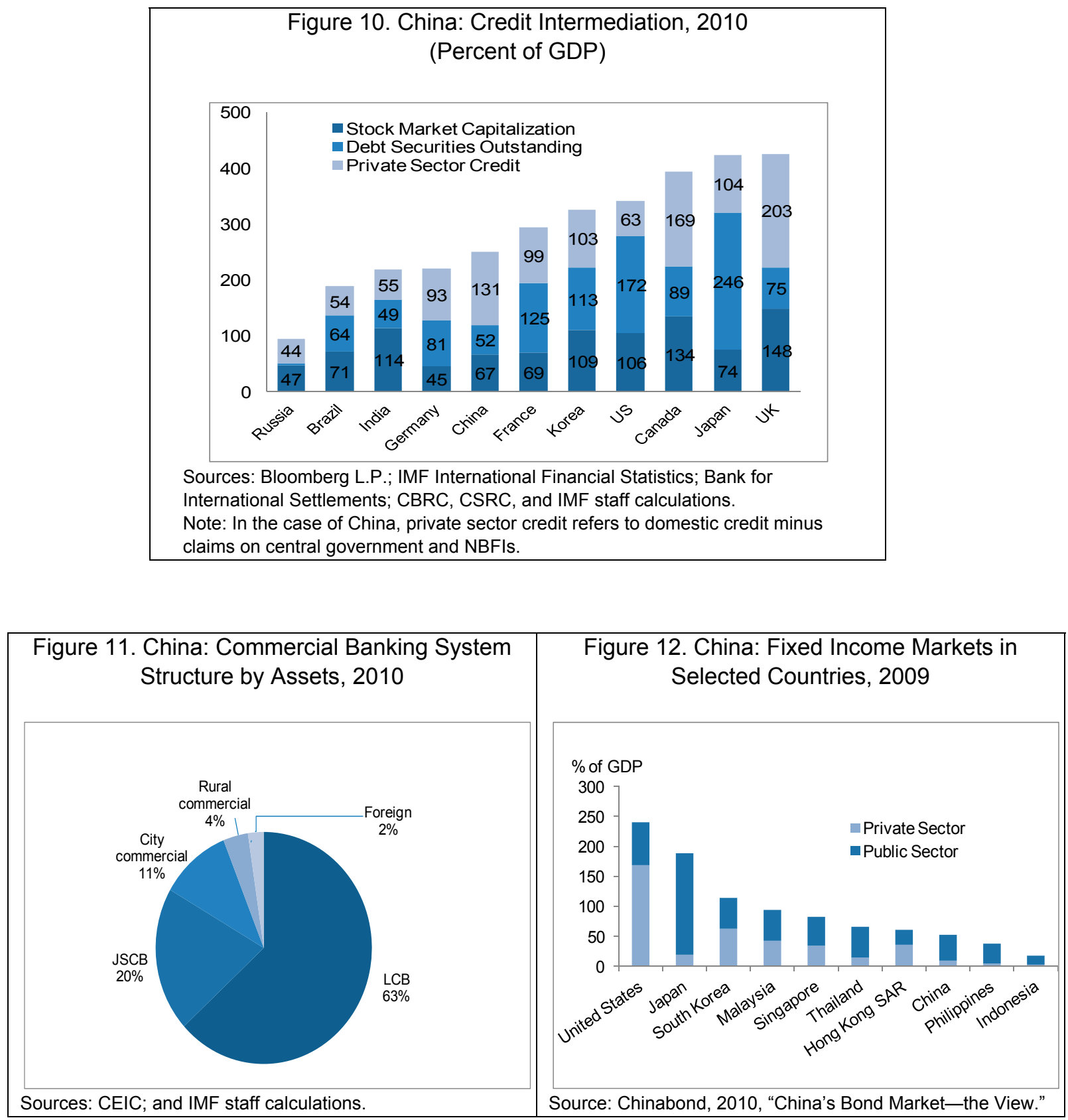
18. While China's financial markets are still in a development phase, cross-market integration has been increasing. There is distinct separation within domestic markets (for example, the domestic bond market is divided into exchange traded/retail and interbank/wholesale markets) and between Chinese markets and the international financial markets (in part, due to widespread capital controls). Nonetheless, shocks do get transmitted across different domestic markets, as illustrated by a positive correlation of yields. Connectivity between markets is likely to grow fast.

\section{Linkages among the banks are mainly transmitted through the interbank repo}

market. The repo market is necessary for many small banks and nonbanks to fund their activities, and for larger banks to place their surplus funds. Consequently, it is the market through which a liquidity squeeze in one part of the banking system can and does spread to others (Section I.C).

\section{Inter-connections between banks and nonbank financial institutions (NBFI)}

have begun to grow. Laws and rules permit more complex structures even though supervisors are challenged to meet the key elements of the principle of consolidated supervision. Interlinkages are increasing with the rise of FHCs, which have expanded considerably since the initiation of a pilot program on integrated financial services under the $11^{\text {th }}$ Five-Year Plan (2006-10) and industrial-financial integrated groups have developed rapidly. At the same time, regulatory policies applying to shadow banking and their interconnections needs to be clarified and made transparent. A more structured oversight, regulatory, and supervisory approach is needed to prevent and to manage systemic risks via cross-market products and institutional structures.

\section{Finally, the financial linkages between China and the rest of the world have} historically been limited, but are growing rapidly. The growth in RMB deposits in Hong Kong SAR has been rapid (Figure 13), though the amount is insignificant relative to the RMB onshore deposits. Cross-border portfolio capital investment is subject to Qualified Domestic Institutional Investor (QDII) and Qualified Foreign Institutional Investor (QFII) programs. ${ }^{2}$ The markets for B shares, through which foreign investors are allowed to invest in China's stock exchange markets, and H shares (China companies listed in Hong Kong Stock Exchange) are eclipsed by the markets for A shares (Figure 14). In addition, the financial transmission between A share and $\mathrm{H}$ share is still limited (Figure 15). While the balance sheet positions of China's banking system vis-à-vis banks located in other countries do not yet fully match the interlinkages of the world's leading banking centers, they have increased by 80 percent in the last ten years.

\footnotetext{
${ }^{2}$ The aggregate quota for the 88 QDII participants was US $\$ 68.4$ billion at end-2010, which accounted for about 0.6 percent of domestic deposits. Under the QFII, 106 foreign institutional investors shared the aggregate quota of US\$ 19.7 billion at end-2010, which accounted for about 0.3 percent of domestic bond and equity market capitalization.
} 


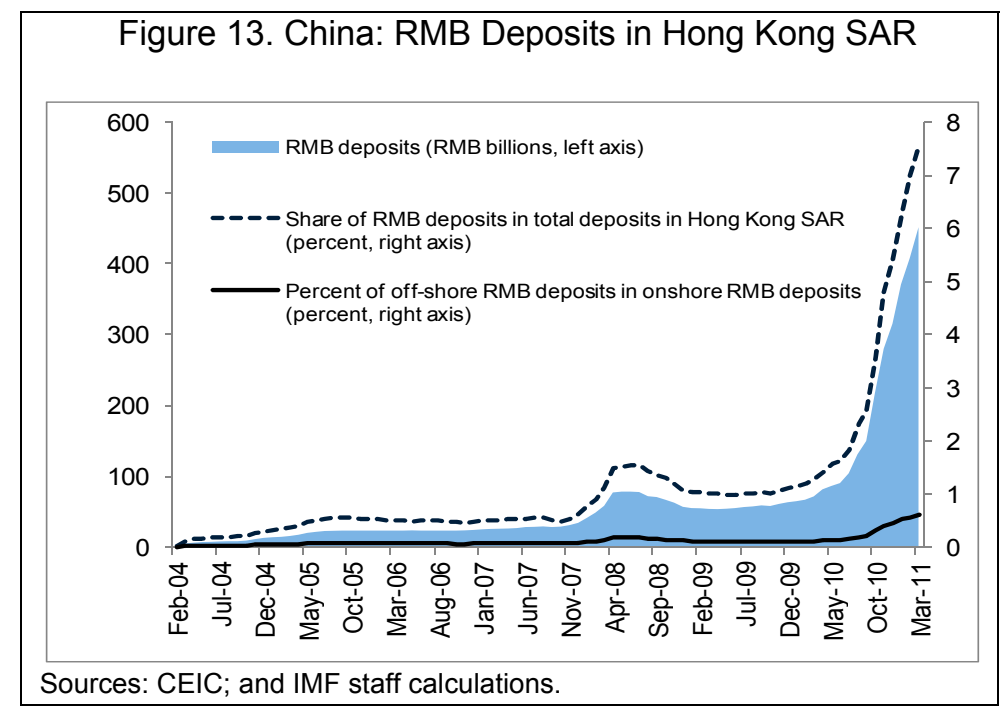

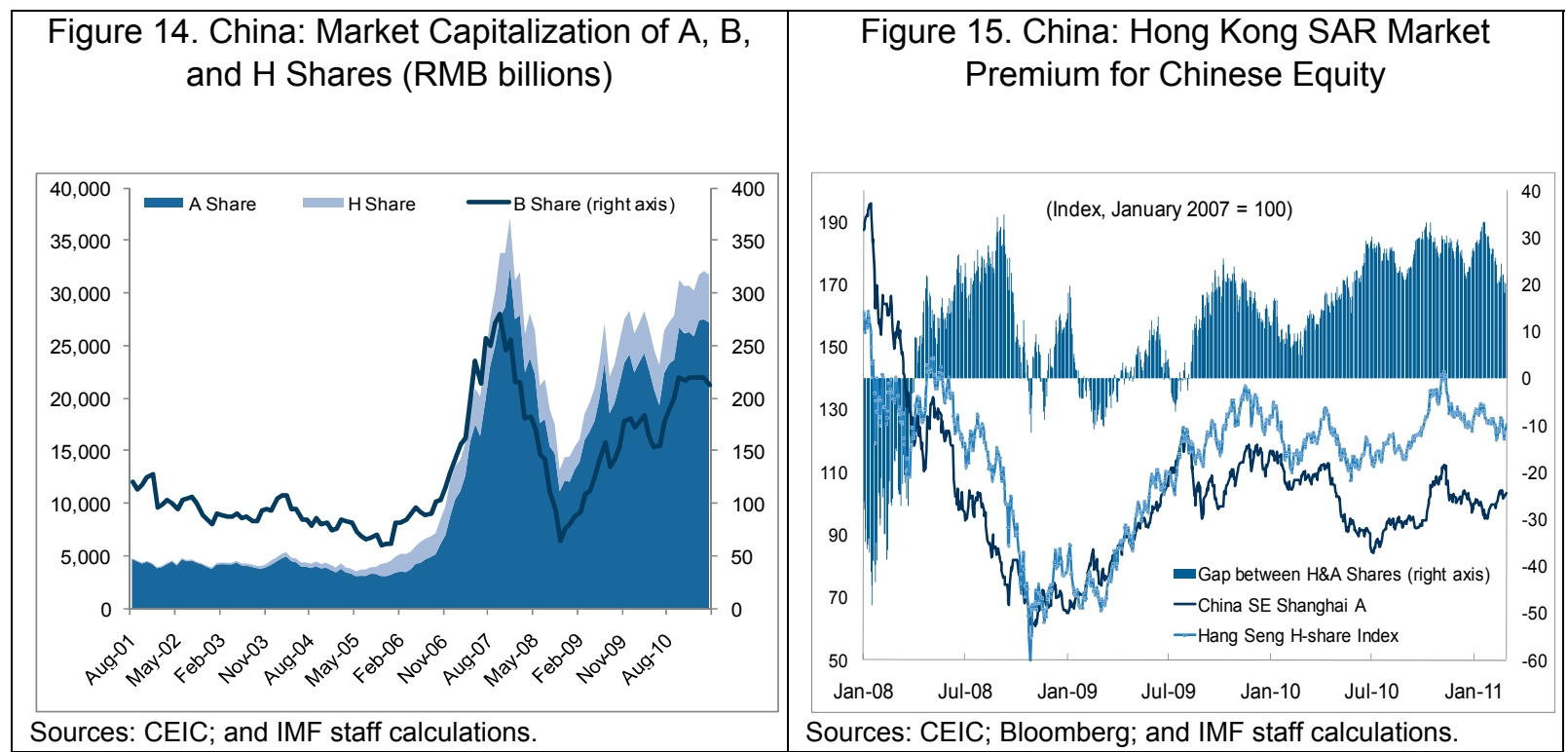

\section{Banking System Performance, Soundness, and Resilience}

\section{The banking sector's balance sheet has expanded rapidly, in part due to the} investment-driven stimulus policies of recent years. In 2009, the total amount of outstanding RMB loans expanded by 33 percent although credit growth slowed down in 2010 (Figure 16). The rapid growth in foreign currency loans is likely linked to the expectation of RMB appreciation. Bank exposure to infrastructure construction increased, driven largely by an expansion of LGFPs, while the share of manufacturing-related loans declined. The upswing in the real estate market also fueled demand for mortgage loans. Banks' off-balance sheet exposures expanded rapidly, mostly as a result of banks' promoting wealthmanagement products as the government began to limit the pace of new lending. 


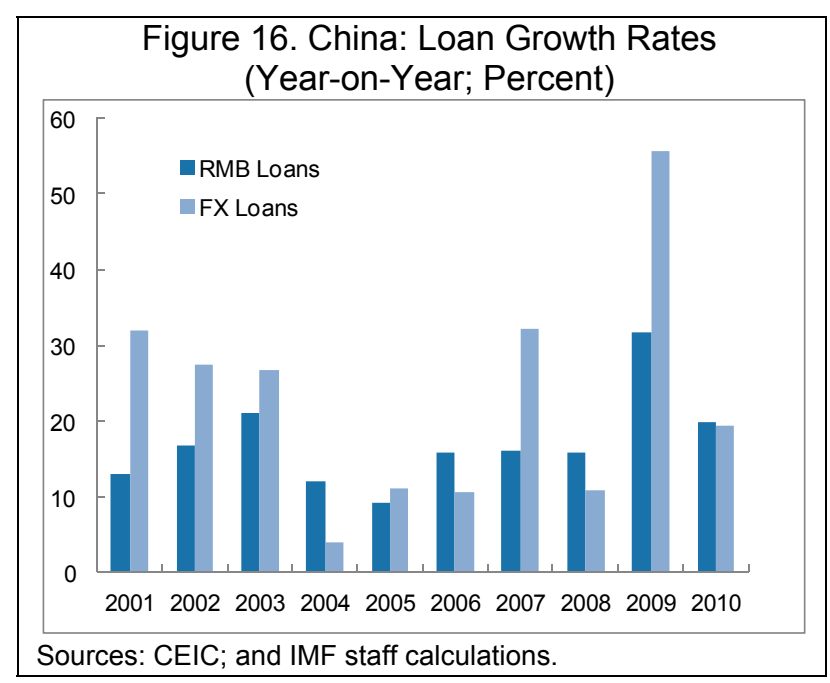

23. Banks' funding appears stable. The sizable and low-cost domestic deposit base has contributed to stable bank funding. While household deposits remained critical to the growth of banks' funding base for most of the reform years, the incremental growth in domestic corporate deposits in 2009 has been significant (Figure 17). Maturity mismatches have also risen. Increasing reliance on medium- and long-term loans for investment project financing has lengthened banks' average asset maturities (Figures 18), particularly for large commercial banks.

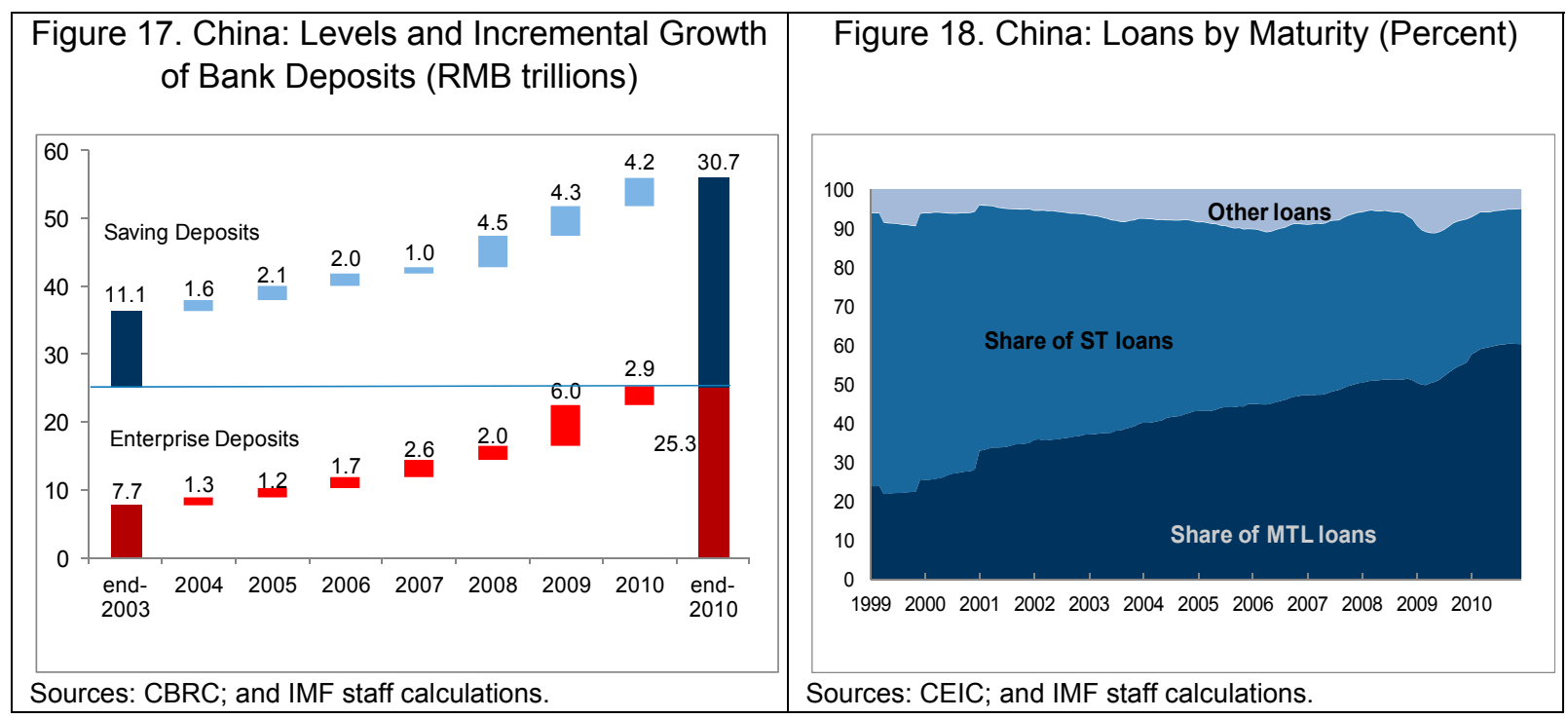

24. Bank profits remain high (Table 6). The credit expansion has supported bank profitability, despite a partial contraction of the interest rate margins in 2009. Chinese banks' limited earning diversification and strong reliance on interest income, however, makes their porfits prone to changes in regulated interest rate margins and limits on lending volumes. 
Table 6. China: Selected Indicators of Financial Health, 2005-10

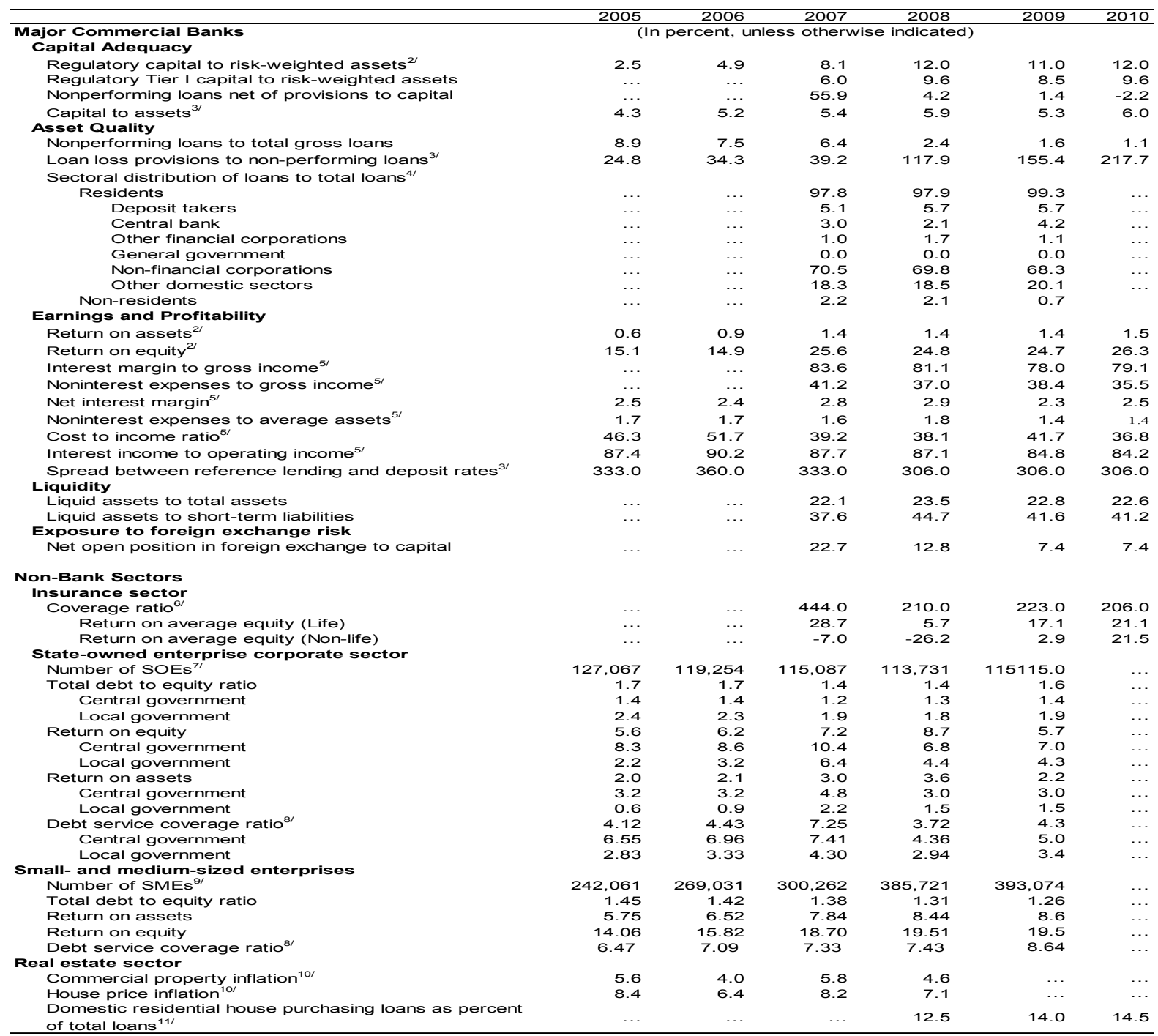

Sources: PBC; MOF; CBRC; CIRC; State -Owned Asset Administration Commission; NBS of China; IMF Global Financial Stability Report; Bankscope; and IMF staff calculations.

${ }^{1}$ All data for this table unless noted otherwise were provided by the Chinese financial regulatory and supervisory commissions in the context of the FSAP. The following footnotes describe some cases in which the figures were obtained from other publically available sources or calculated by the FSAP team.

${ }^{2}$ Comparability across years is limited due to differences in data coverage. Data for 2005 and 2006 refer to the total banking industry as reported in the IMF Global Financial Stability Report, whereas data from 2008 to 2010 refer to the 17 major commercial banks as reported by Chinese authorities to the FSAP team.

${ }^{3}$ Capital adequacy and asset quality indicators were calculated with data from CBRC's 2010 annual report. Capital to assets ratio is defined as equity to assets ratio. Interest rate spreads were calculated with data from PBC's Monetary Policy Reports.

${ }^{4}$ Ratios where the numerator and denominator were compiled on a domestically consolidated basis (DC).

${ }^{5}$ Simple averages of 17 major commercial banks. FSAP team's calculations based on the banks' financial statements and Bankscope.

${ }^{6}$ Available solvency margin over required solvency margin.

${ }^{7}$ Number of non-financial State-Owned Enterprises (SOEs) above Grade Three. The State-Owned Assets Supervision and Administration Commission directly held SOEs are Grade One. Grade One SOEs directly held subsidiaries are Grade Two. Grade Two enterprises directly held subsidiaries are Grade Three.

${ }^{8}$ Earnings before interest and tax as a percentage of interest and principal expenses.

${ }^{9}$ Number of SMEs in the industrial sector.

${ }^{10}$ Percent change in commercial real estate and house price indices.

${ }^{11}$ CBRC's statistics based on credit data on institution (legal person). 
25. The banking systems' nonperforming loan (NPL) ratio has been on a downward trend, reaching 1.1 percent at end-2010 (Figure 19). This decline was driven by the rapid expansion of credit, a decline in NPL levels, and a RMB 816 billion NPL carve-out from one major bank in 2008. Over a longer horizon, large scale NPL carve-outs associated with the 1999-2001 and 2004-05 state-owned bank restructurings have kept overall NPL ratios low. ${ }^{3}$ The low level of reported NPLs has also been helped by strong economic growth and some improvements in risk management in banks. The rapid credit growth, however, could result in a deterioration of bank asset quality in the coming years. In addition, about 95 percent of bank loans re-price in under one year; this could lead to higher borrowing costs and loan servicing problems for weak borrowers if the PBC moves along a tightening cycle.

26. Exchange rate exposure is large at the central bank. Large current account surpluses and the management of the exchange rate regime result in the accumulation of sizeable foreign exchange reserves and a large net open foreign currency position for the central bank. Commercial banks, in aggregate, are also long in foreign assets (Figure 20) though in a much smaller scale.

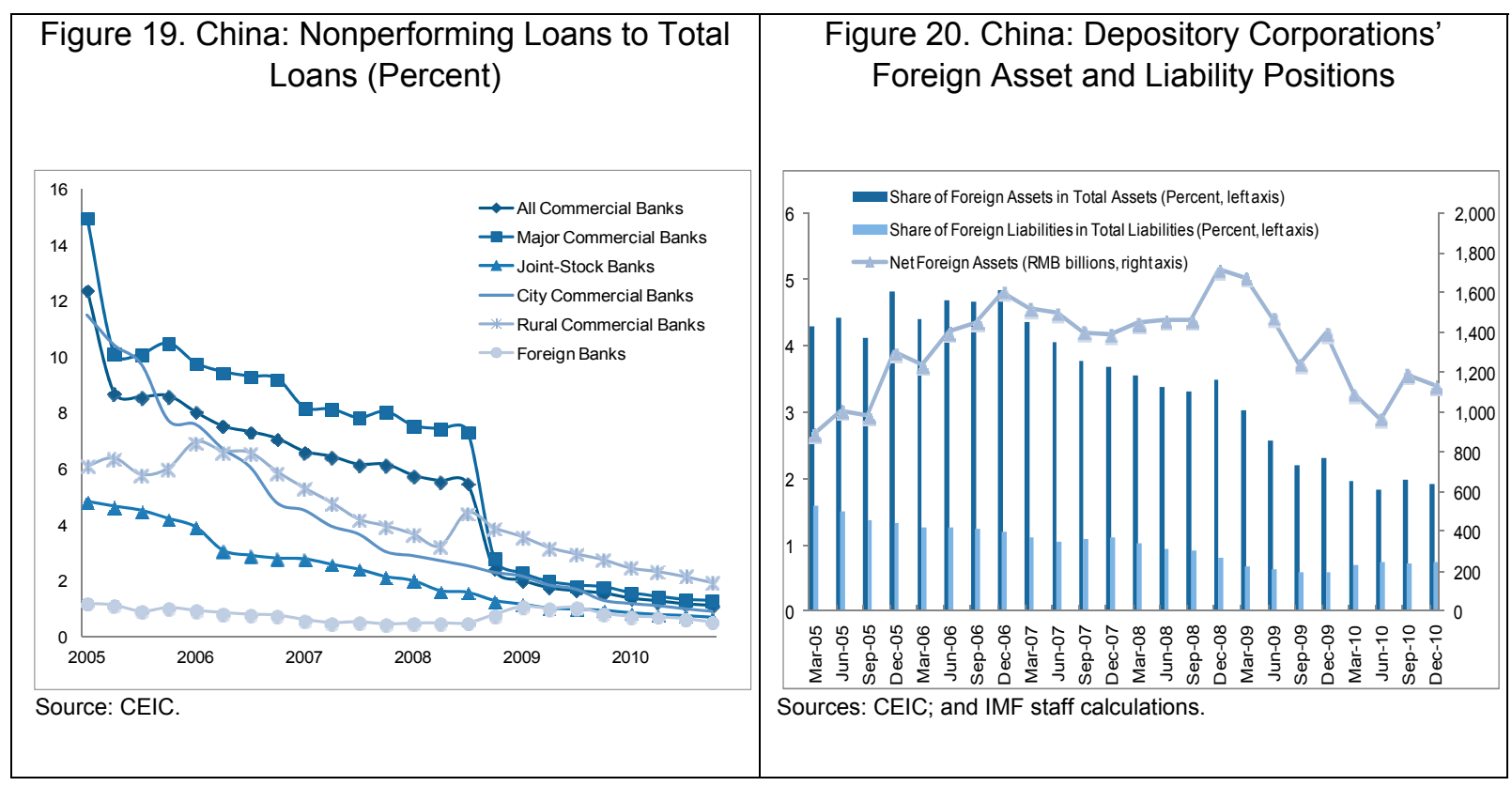

27. The near-term risks of liquidity stress appear limited. The banking sector's basic liquidity indicators appear healthy. Larger banks typically recycle liquidity through the interbank markets to smaller banks and other financial institutions (Figures 21 and 22).

\footnotetext{
${ }^{3}$ According to the FSAP team's calculations, as of end-2006, the book value of the non-performing assets transferred to the AMCs amounted to about RMB2.6 trillion.
} 
The dominant share of secured interbank lending, high quality collateral, and abundant liquidity limit the prospects of market stress in the near term. Interbank markets, however, are subject to some risks. There are persistent liquidity imbalances among the banks, with small banks and non-banks particularly reliant on wholesale funding. A localized liquidity squeeze could spread from a small set of institutions that face a liquidity shock and cannot realize the face value of their pledged security to a broader liquidity shock. The PBC standing facilities should act as a liquidity backstop when liquidity is unavailable from the market.

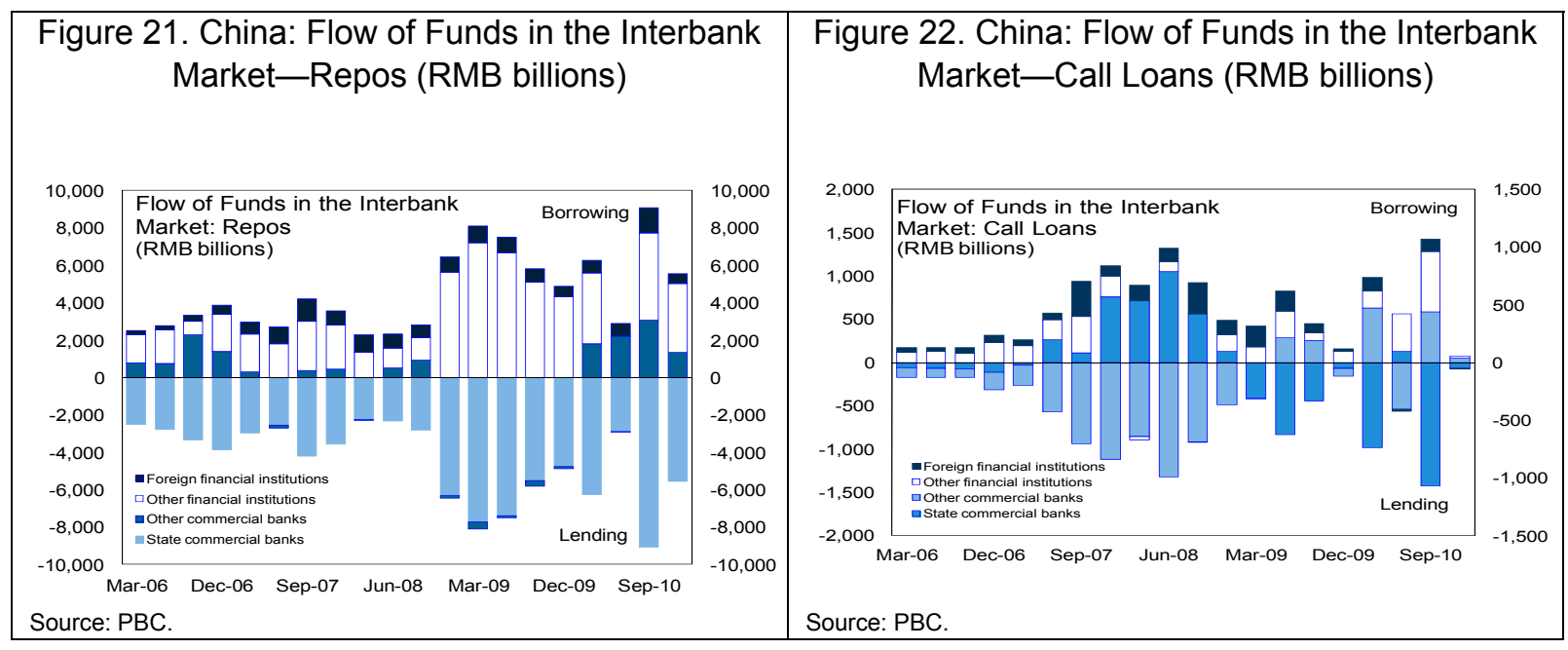

\section{Stress-Testing Results Summary}

28. To capture the key risks of the Chinese financial system, a stress testing exercise was jointly conducted by the FSAP team and PBC/CBRC team. ${ }^{4}$ The results of the PBC/CBRC team's top-down and banks' bottom-up calculations - based on a sample of 17 banks - were provided to the FSAP team at the aggregate level and by bank type. The FSAP team also carried out its own set of top-down calculations, based on publicly available data on the same set of 17 banks.

\section{Caveats}

29. A full assessment of the extent of the risks and how they could permeate through the economic and financial system was hindered by various factors. First, it was not feasible to fully cover all the differentiated risks confronting the banking system due to data constraints on the sectoral exposures and types of entities that banks lend to. Also, data constraints prevented an explicit analysis of off-balance sheet positions and operations, except for those relating to the direct exchange rate risk. Moreover, much of the calibration

\footnotetext{
${ }^{4}$ See Table 7 and Appendix I for the methodology.
} 
Table 7. China: Stress Tests for Banks

\begin{tabular}{|c|c|c|c|c|}
\hline & & \multicolumn{2}{|c|}{ Solvency Stress Tests } & \multirow[t]{2}{*}{ Liquidity Stress Tests } \\
\hline & & Sensitivity Stress Tests & Scenario Stress Tests & \\
\hline 1 & $\begin{array}{l}\text { Who } \\
\text { performed the } \\
\text { stress tests }\end{array}$ & \multicolumn{2}{|c|}{$\begin{array}{l}\text { Three complementary approaches: FSAP team; PBC/CBRC team; and } \\
\text { banks following the guidelines } \\
\text { - The results of the PBC/CBRC team's top-down and banks' bottom-up } \\
\text { calculations were provided to the FSAP team at the aggregate level, as well } \\
\text { as disaggregated by bank type } \\
\text { - These were then cross-checked by the FSAP team using publicly available } \\
\text { data }\end{array}$} & - Banks \\
\hline 2 & $\begin{array}{l}\text { Institutions } \\
\text { covered/market } \\
\text { share }\end{array}$ & \multicolumn{2}{|c|}{$\begin{array}{l}\text { - } 17 \text { major banks ( } 5 \text { large commercial banks and } 12 \text { joint stock commercial } \\
\text { banks), accounting for } 83 \text { percent of commercial banking system ( } 66 \\
\text { percent of banking system) assets at end- } 2010 \\
\text { - Contagion risk analysis was done on } 5 \text { large commercial banks, accounting } \\
\text { for } 63 \text { percent of commercial banking system ( } 50 \text { percent of banking } \\
\text { system) assets at end-2010 }\end{array}$} & $\begin{array}{l}17 \text { major banks, accounting } \\
\text { for } 83 \text { percent of commercial } \\
\text { banking system ( } 66 \text { percent } \\
\text { of banking system) assets at } \\
\text { end- } 2010\end{array}$ \\
\hline 3 & $\begin{array}{l}\text { Severity of } \\
\text { shocks }\end{array}$ & $\begin{array}{l}\text { - Aggregate credit: } 100-400 \text { percent } \\
\text { increase of NPLs; threshold approach } \\
(10,25,50 \text { percent of banks below } \\
\text { minimum CAR, } 2,4,6 \text { percent GDP } \\
\text { capital injection) } \\
\text { - Concentration credit risk: Sectoral NPL } \\
\text { ratio increases to } 5,10,15 \text { percent or } \\
\text { NPLs increase by } 100,200,400 \text { percent. } \\
\text { Sectors include largest borrowers } \\
\text { default, real-estate related risk (two } \\
\text { types), exposures to LGFPs, exposures } \\
\text { to "overcapacity industries", exposures } \\
\text { to export-oriented sector, and exposures } \\
\text { to sectors (industries) and regions with } \\
\text { the most rapid loan growth } \\
\text { - Market risk: Interest rates: } 54,81 \text {, } \\
\text { 108bps parallel shift up and } 18,27, \\
\text { 36bps fall in benchmark loan rate in } \\
\text { banking portfolio; } 50,100,150 \text { bps shift } \\
\text { up in trading portfolio; exchange rate: } 5 \text {, } \\
\text { 10, and } 15 \text { percent appreciation }\end{array}$ & $\begin{array}{l}\text { Three scenarios } \\
\text { - Mild: GDP ( } 7 \text { percent), M2 } \\
\text { (14.7 percent), real estate } \\
\text { price (-7 percent), interest } \\
\text { rate ( } 35 \text { bps change), REER } \\
\text { (117.5) } \\
\text { - Medium: GDP ( } 5 \text { percent), } \\
\text { M2 (12.4 percent), real } \\
\text { estate price (-16.2 percent), } \\
\text { interest rate (66bps), REER } \\
\text { (119.6) } \\
\text { - Severe: GDP ( } 4 \text { percent), } \\
\text { M2 (10.2 percent), real } \\
\text { estate price (-25.9 percent), } \\
\text { interest rate ( } 95 \text { bps), REER } \\
\text { (123.0) } \\
\text { Note: calibration reflects a } \\
\text { survey among a panel of } \\
\text { prominent experts on Chinese } \\
\text { economy }\end{array}$ & $\begin{array}{l}\text { Three scenarios for each risk } \\
\text { horizon: } \\
\text { - } 7 \text {-day: bond prices drop }(1,3 \text {, } \\
5 \text { percent }) \text {; deposit draw- } \\
\text { down }(2,4,6 \text { percent); } \\
\text { interbank down }(5,10,15 \\
\text { percent); required reserve } \\
\text { ratio up }(0,0.5,1 \mathrm{pp}) \\
\text { - } 30 \text {-day: }(4,7,10 \text { percent }) \\
\text { maturing loans become } \\
\text { NPLs; bond prices drop }(3,5 \text {, } \\
8 \text { percent }) ; \text { deposit draw- } \\
\text { down }(4,6,8 \text { percent }) ; \\
\text { interbank down }(5,10,15) ; \\
\text { required reserve ratio up }(0, \\
\text { 0.5, 1pp) }\end{array}$ \\
\hline 4 & Data used & \multicolumn{2}{|c|}{$\begin{array}{l}\text { - FSAP team: publicly available data } \\
\text { - Authorities: supervisory and audited data } \\
\text { - Banks: data from the internal risk management systems }\end{array}$} & $\begin{array}{l}\text { - Data from the banks' internal } \\
\text { risk management systems }\end{array}$ \\
\hline 5 & Risk horizon & - One quarter, 1 or 2 years & 1 year & - 7 days and 30 days \\
\hline 6 & $\begin{array}{l}\text { Metrics } \\
\text { (hurdles rates) }\end{array}$ & \multicolumn{2}{|l|}{ - Minimum capital adequacy ratio (8 percent) } & $\begin{array}{l}\text { - Liquidity ratio (25 percent) } \\
\text { - Liquidity gap (zero) }\end{array}$ \\
\hline 7 & $\begin{array}{l}\text { Positions and } \\
\text { risk factors } \\
\text { included }\end{array}$ & $\begin{array}{l}\text { On-balance sheet position for all } \\
\text { positions except for those related to the } \\
\text { direct exchange rate risk } \\
\text { - Credit risk, market risk, and contagion } \\
\text { risk }\end{array}$ & On-balance sheet position & - Assets and liability positions \\
\hline 8 & Methodology & $\begin{array}{l}\text { - Balance sheet approach }(\mathrm{LGD}=50 \\
\text { percent) } \\
\text { - Zero credit growth } \\
\text { - Zero profits } \\
\text { - Zero provisions }\end{array}$ & $\begin{array}{l}\text { - Authorities: econometric } \\
\text { model } \\
\text { - Bank: a combination of } \\
\text { econometric models and } \\
\text { expert-based approaches } \\
\text { - FSAP team: cross-checks } \\
\text { based on international } \\
\text { experience }\end{array}$ & $\begin{array}{l}\text { Tests combine funding liquidity } \\
\text { with haircut on liquid assets }\end{array}$ \\
\hline
\end{tabular}

Source: FSAP stress testing team. 
in the macro-scenario tests was based on relatively short time series of key financial data (e.g., for NPLs) with structural breaks in the series; this limited a solid econometric analysis. Full-fledged comparison, analysis, and cross-check of the results were not possible in areas where publicly available information is imprecise, insufficient, or nonexistent (e.g., exposures to LGFPs and the contagion risk exercise) due to the constraints on the FSAP team's access to confidential data. Finally, the stress tests assumed the status quo (i.e., current macro-financial environment). As reforms begin in earnest, the banking system may face an amplification of existing risks or new uncertainties - although a properly implemented reform process and stronger risk management and corporate governance practices will help mitigate adverse financial consequences.

\section{Keeping these caveats in mind, the stress testing results suggest that major}

banks can absorb moderate potential losses. This reflects improved profitability and balance sheets in recent years, which allowed banks to build up buffers. The single-factor sensitivity calculations indicate that the system would be able to withstand a range of sectorspecific shocks occurring in isolation. These specific shocks include asset deterioration in bank credit to the real estate sector, LGFPs, export sector, and other sectors. The macroeconomic scenario analysis suggests, however, that the system could be severely impacted if several major shocks materialized concurrently.

\section{Credit risks}

\section{The system appears able to withstand relatively sizeable aggregate increases in} credit risk (Figure 23). If NPL levels were to increase by 400 percent in two years (i.e., postshock NPL ratio reaching about 6 percent), calculations based on end-2010 data suggest that no banks would have capital adequacy ratio (CAR) below the regulatory minimum (i.e., 8 percent). The improvement in resilience from 2008 to 2010 reflects the decline in NPL levels. In addition, the buffer provided by stronger bank capital positions in 2010 helped prevent participating banks from failing to meet the regulatory minimum CAR under the most severe assumptions.

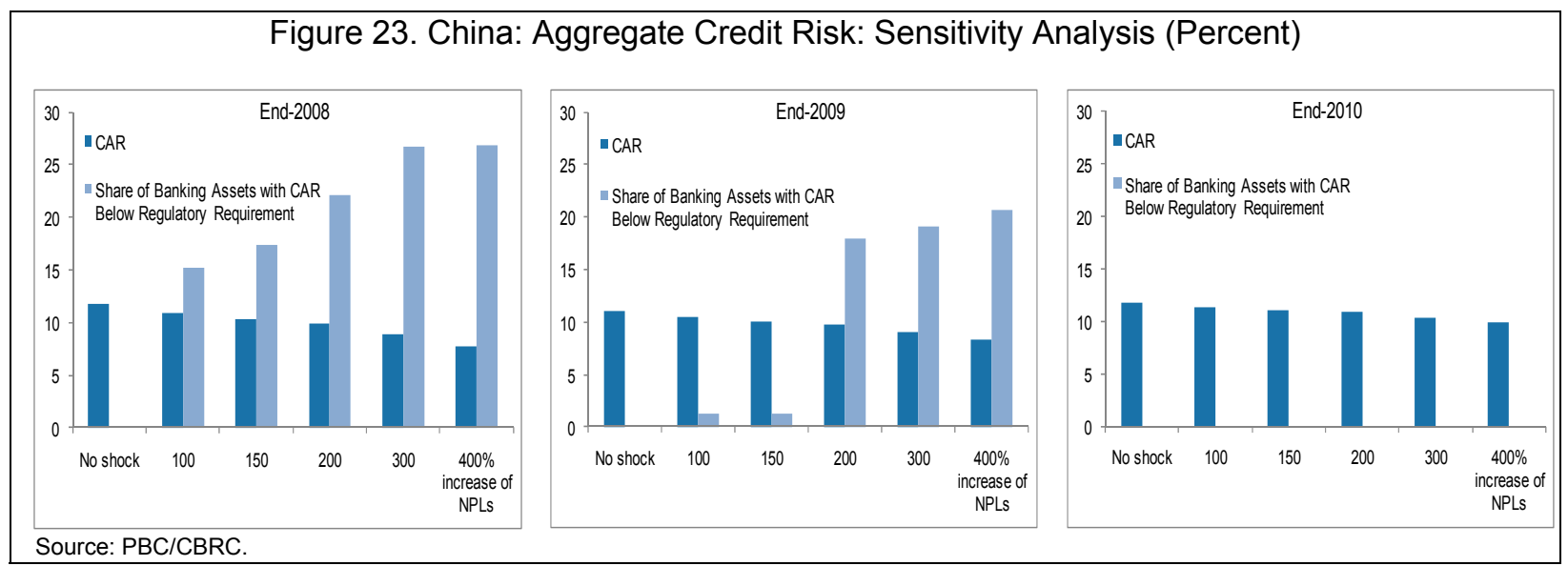


32. The resilience was also confirmed by a reverse stress test ("threshold approach") conducted by the FSAP team and PBC/CBRC team. For instance, based on end-2009 data, for half of the banking system (in terms of total assets) to breach the regulatory minimum CAR, the ratio of gross NPLs to total loans would have to increase to almost 11 percent. Or, assuming that the banking system requires a capital injection of 6 percent of GDP, the NPL ratio would need to reach 24.8 percent (compared with 1.6 percent at end2009).

\section{Stress tests conducted by the PBC/CBRC team and the banks indicate the} impact of credit quality deterioration from a shock to the real estate sector would be contained. Two tests were conducted. The first test, conducted by the PBC/CBRC team and individual banks, involved assuming NPLs increase in the segments of personal mortgage loans, real estate development loans, and land reserve loans. Based on end-2010 data, if 15 percent of developer and land reserve loans, as well as $71 / 2$ percent of mortgages become nonperforming, the aggregate CAR falls by about 1 percentage point but no banks fall below the regulatory minimum (Figure 24 ). The second test, conducted by individual banks, was an expanded version of this first exercise whereby - in addition to the three segments listed above - the impact of the real estate price decline was carried through to create insolvencies in six industries that are "vertically integrated" with the real estate. ${ }^{5}$ A 30 percent decline in property prices, higher interest rates, and the resulting impact on related industries has only a minimal impact, lowering the aggregate CAR by less than $1 / 4$ percentage point (Figure 25).

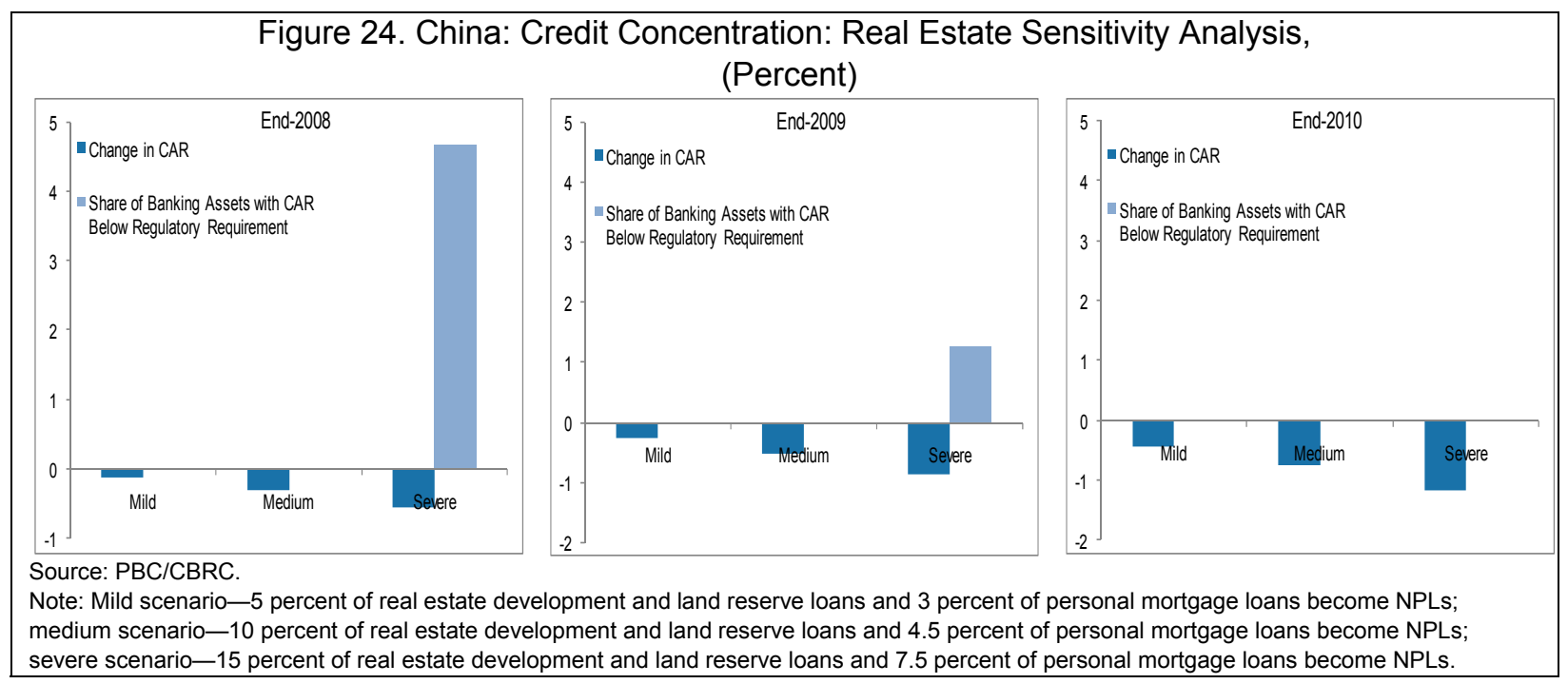

\footnotetext{
${ }^{5}$ The industries are (i) steel-making; (ii) cement, lime and plaster manufacturing; (iii) brick, stone and other building materials manufacturing; (iv) building construction; (v) furniture making; and (vi) household electrical apparatus manufacturing.
} 


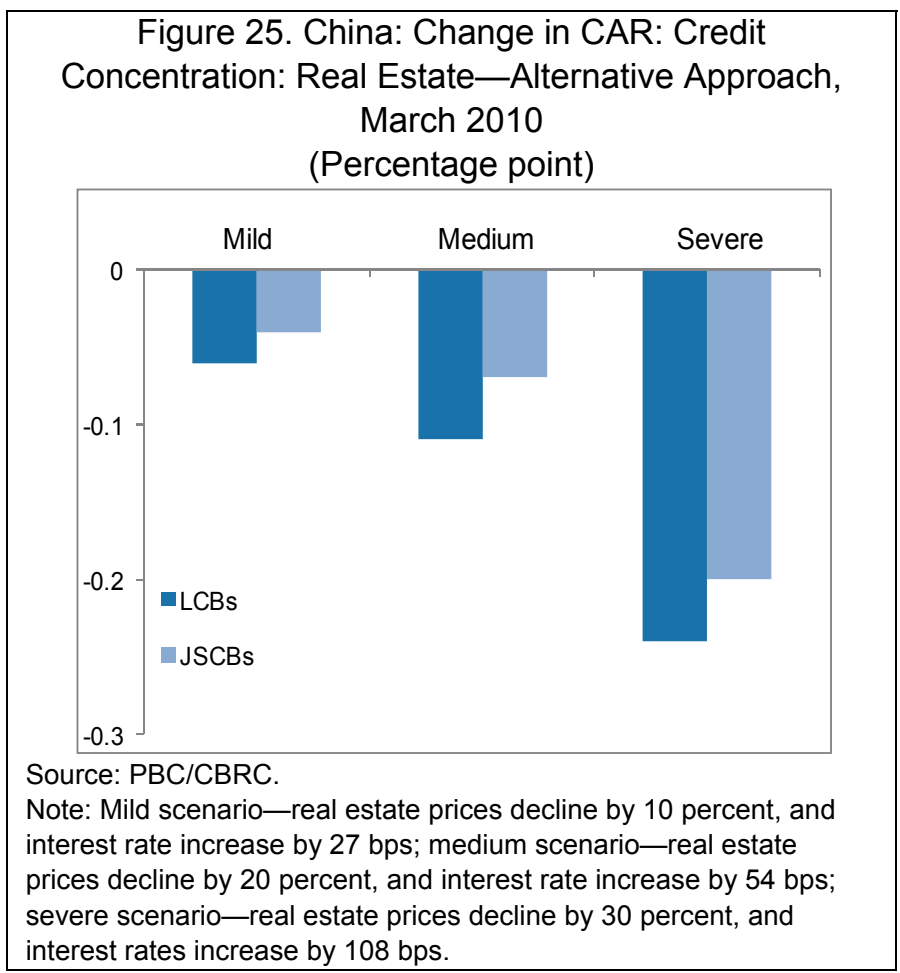

34. The stress testing exercise has also assessed the potential losses on LGFP

lending. The results show that, based on a bottom-up stress test conducted by individual banks, losses equivalent to15 percent of the banks' LGFP loans would result in a fall in the CAR to below the regulatory minimum for only two small joint-stock commercial banks (JSCBs) (Figure 26).

\section{Direct interest rate risk}

35. Direct interest rate risks on banking book and trading book appear manageable. Shocks to loan and deposit rates were used in the analysis, and their impacts were evaluated by the PBC/CBRC team and individual banks in terms of the implied change in the CAR. The results suggest that even under the severe combination of shocks, the CARs for all the 17 banks declined slightly (Figure 27). The risk of a parallel shift of yield curve on trading accounts was also tested by individual banks and the results again suggest the impact would be very small (Figure 28).

\section{Direct exchange rate risk}

36. The direct impact of exchange rate movements on the banking system would be limited. The results of the PBC/CBRC team's top down and individual banks' bottom-up stress tests suggest that under the severe stress scenario, the CAR for the system as a whole falls by less than 0.1 percentage point and the CARs for all 17 banks would still exceed the minimum requirement (Figure 29). 
Figure 26. Test for Banks' Exposures to LGFPs, End2009

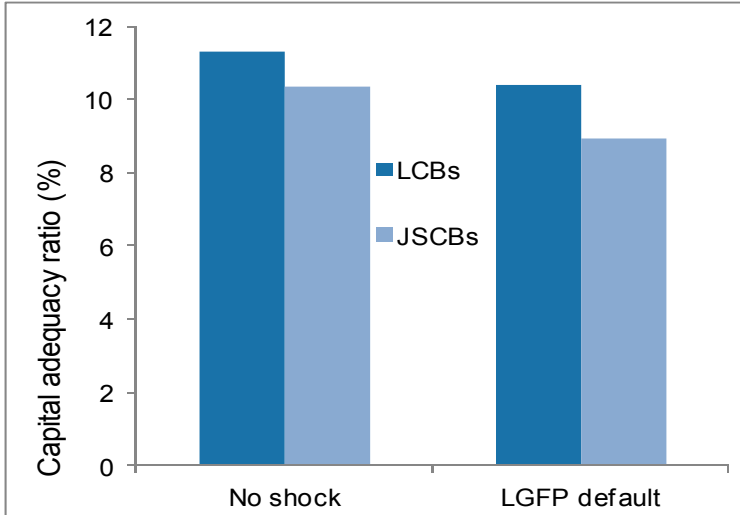

Key assumptions:15 \%of LGFP loans default. Loss given default is $50 \%$.

Source: PBC/CBRC.

Note: The information on Banks' exposure to LGFPs is not made available to

the FSAP stress testing team.

Figure 27. China: Interest Rate Risk: Banking Book, End-2009

(Percentage point)
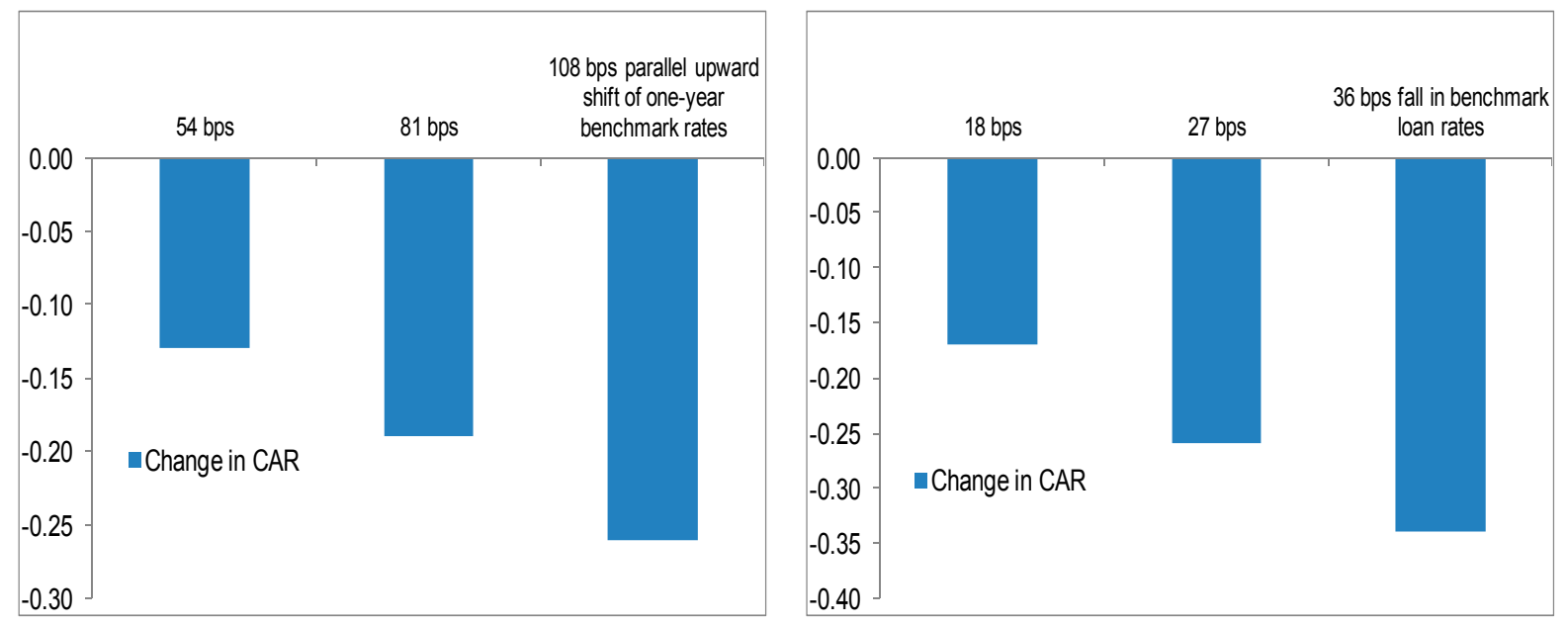

Source: PBC/CBRC.

\section{Liquidity risk}

37. Two rounds of liquidity risk stress tests have been conducted. The results suggest that in the first round (i.e., without considering banks' ability to sell off bonds) the impact could be substantial, with, for instance, six banks having a negative cash flow gap at the seven day horizon. The results of the second round, which assume that banks are able to sell off bonds at a discount, are more benign, with all banks except one (at the 30 day horizon) having positive cash flow gaps. 


\begin{tabular}{|l|l|l|}
\hline $\begin{array}{c}\text { Figure 28. China: Interest Rate Risk: Trading } \\
\text { Accounts, End-2009 } \\
\text { (Percentage point) }\end{array}$ & $\begin{array}{c}\text { Figure 29. China: Direct Exchange Rate Risk, } \\
\text { End-2009 } \\
\text { (Percentage point) }\end{array}$ \\
\hline \\
\hline
\end{tabular}

\section{Macro-scenario tests}

38. The macroeconomic scenario analysis suggests a severe impact on the system if several major shocks materialized concurrently (Figure 30). For example, a severe scenario (involving a slowdown in GDP growth to 4 percent year-on-year) implies a systemwide CAR of about 8 percent, with banks accounting for some $1 / 4$ of the total assets of the 17 banks covered by the stress tests falling below the 8 percent minimum CAR. It is encouraging also that the results of the scenario analysis were broadly consistent with the suggestive conclusions drawn from a survey of available results in previous FSAPs (i.e., in a major slowdown of GDP), NPL ratios tend to increase by at least one percentage point for each one percentage point decrease in the rate of output growth.

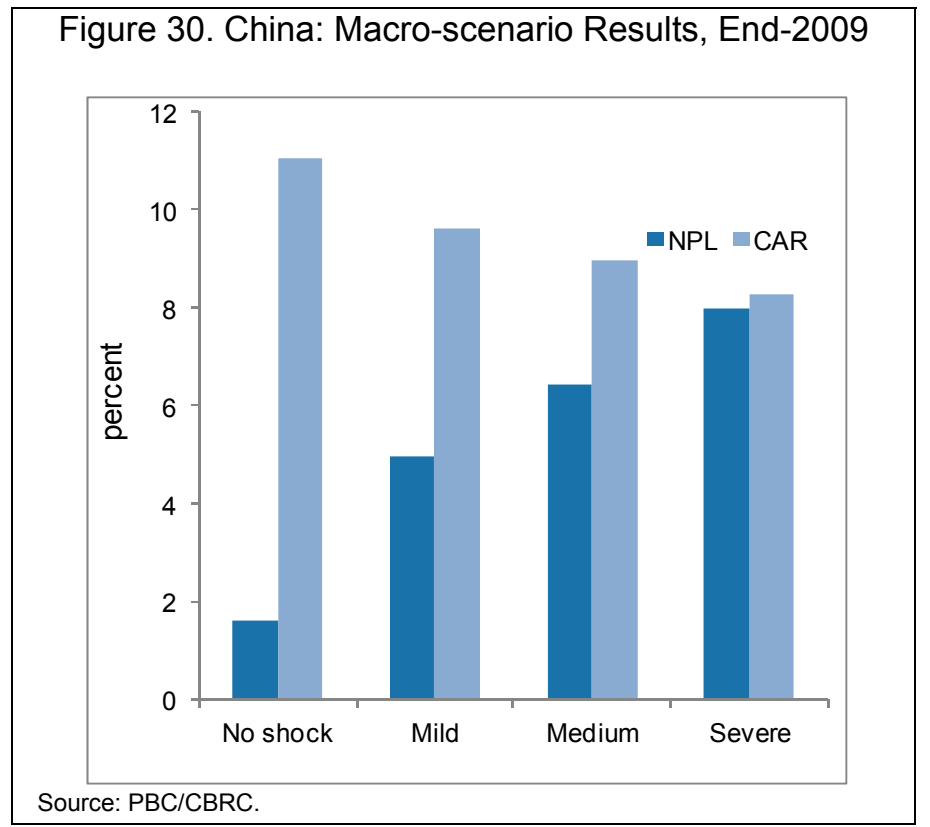




\section{Managing Risks: Upgrading The CRISIS ToOlKIT}

\section{A. Financial Stability Framework}

\section{To enhance macro-prudential surveillance, a permanent Financial Stability} Committee should be established, with the PBC as its secretariat. It should be chaired by a very senior official and have a clear mandate and authority to identify and monitor the emergence of systemic risks and to make recommendations to address them. Members would include the $\mathrm{PBC}$, the three supervisory commissions, the MOF, and other relevant ministries or agencies. The PBC, as the Committee's secretariat, along with each of the commissions would be empowered to provide and to receive necessary information, including confidential institution-specific supervisory information.

\section{Data collection should be enhanced to facilitate a good understanding of} financial institutions' balance sheets and linkages. Such data should include the level of leverage, maturity mismatches, large exposures, contingent liabilities, off-balance sheet positions, unregulated products, and cross-border and sectoral (e.g., housing, local government) exposures, which in turn requires improving data collection on financial institutions' non-financial counterparts. Development of a forward-looking early warning system incorporating macro and financial indicators, financial soundness indicators, systemic risk indicators, and balance sheet information would help identify macroeconomic and financial developments with a potential to threaten the financial system.

\section{Continued efforts are needed to build a comprehensive macro-prudential} framework for measuring and managing systemic risks. China already has several macroprudential tools to handle these risks, including capital surcharges for systemically important financial institutions (SIFIs), dynamic provisioning, variable capital requirements, reserve requirements, and requirements related to loan-to-value and loan-to-deposit ratios. A clear indication of how these buffers and requirements may vary as conditions change needs to be developed. Increasing the PBC's and the regulators' resources and capacity to monitor financial stability and carry out regular stress tests is also needed.

\section{B. Systemic Liquidity Management}

\section{The PBC should begin to absorb the significant liquidity overhang that is} currently present in the financial system. This will involve a much more aggressive use of open market operations to reach a point where the PBC no longer needs to rely on administrative limits on bank lending. As liquidity conditions tighten, banks will have incentives to improve their internal liquidity management functions and focus more on assessing risk-return trade-offs in allocating loans. 
43. At the same time, considering reserve averaging would be a useful step. Its introduction could facilitate liquidity management and enhance stability and efficiency. The daily nature of the reserve requirement means that it is principally an aggregate liquidity management tool rather than a prudential buffer for banks. Banks end up holding substantial under-remunerated excess reserves for buffer purposes - effectively an additional tax on intermediation. Across the banking system these reserves have averaged around 2-3 percent of deposits, but the actual holdings vary substantially by type of bank. Therefore, reserve averaging could help reduce this additional tax and make liquidity management for all, particularly smaller, institutions easier, and limit the possibility for liquidity stresses to transmit across institutions.

44. The central bank should begin by targeting a short-term repo rate. To further strengthen the management of short-term interest rates, the central bank could raise the rate paid on excess reserves to narrow the corridor implied by the difference with its discount rate. To support the use of indirect instruments and supplement structural liquidity withdrawal, the PBC could lengthen the maturity of its open market operations through greater use of longer-term repos.

\section{Overtime, the PBC should enhance its capacity to undertake daily liquidity} operations. Recent international experience has demonstrated the potential for a liquidity crisis to occur even when liquidity appears abundant. The PBC needs to implement higher frequency liquidity forecasting, which in turn requires an increased flow of information among the MOF, State Administration of Foreign Exchange (SAFE), and the PBC.

\section{Access to the PBC's standing facilities should be made more automatic and} transparent, with moral hazard concerns addressed through pricing of the facilities. The PBC exercises considerable discretion over access to standing facilities, complicating and potentially delaying the disbursement of funds. This could be addressed by reducing PBC's discretion and making the use of each facility automatic, with collateral requirements identical across all domestically incorporated institutions. This would also strengthen PBC interest rate guidance by providing a binding and effective interest rate corridor.

\section{Crisis Management, Resolution, and Deposit Insurance}

\section{China's crisis management arrangements fall under the purview of the State}

Council (SC). The resolution toolkit needs to be expanded as the financial system is becoming complex. The current toolkit is essentially based on an "open resolution" approach towards nonviable banks and an implicit blanket guarantee for depositors, with the PBC in practice taking responsibility for backing up deposits. This implies significant moral hazard. A more comprehensive toolkit would comprise a safety net and an effective institutional arrangement in which relevant authorities have operational autonomy and legal authority to intervene promptly in weak and nonviable financial institutions. 
48. The introduction of an explicit deposit insurance scheme, which is under consideration, should be accelerated to provide a structured safety net. It will also help facilitate the orderly resolution of failing banks. The design features should incorporate the principles being developed by the International Association of Deposit Insurers. Its institutional structure should be appropriately designed taking into account the large number of depository institutions, growing complex structures, existing roles of various organizations in a resolution, and the need to clarify the contingent liability of the government, particularly of the PBC, when resolving failed institutions.

49. Laws concerning the insolvency of financial institutions need to be reviewed and strengthened in all sectors. A designated separate entity should be provided with the capacity to manage the intervened institution and with resources to resolve the institution through recapitalization, sale, in whole or in part, or liquidation. The entity should be funded by industry to reduce if not eliminate the need to rely on government support. The institutional capacity to deal with troubled assets in failed institutions is an important component. The entity could assume responsibility for administering the deposit insurance scheme and assets of failed institutions. As for the existing four public AMCs, a strategy is needed. As a first step, the AMCs should be required to publish periodic financial statements and management reports and eventually, most, if not all, should be converted into commercial entities.

\section{Macro-Financial Framework}

50. The linkages between the macroeconomic policy framework and financial sector are intrinsic to financial stability in China. It is for this reason that while the financial system looks stable in prudential terms, with a small level of problem loans, extensive credit provisioning, and (still) low leverage of main borrowers, allocative inefficiencies, and structural vulnerabilities still remain. As stated earlier, commercial banks often act as the channel of monetary policy and as facilitators of fiscal policy. The existing policy framework thus creates large distortions to incentives and places risk on the public balance sheet as contingent liabilities. While improvements in risk management, prudential regulation, and supervision remain necessary, and need to be strengthened, the further deepening and maturation of the financial system will be addressed in a large part by the process by which the macroeconomic policy framework evolves.

\section{The PBC should rely more on indirect monetary policy instruments to exercise} macroeconomic control. Instead of credit growth targets, market-based interest rates should become the primary instrument for managing credit expansion. This will reduce the risks that monetary control will be increasingly circumvented and ineffective in the face of capital inflows, off-balance sheet lending, and other financial innovations. It will also enhance banks' scope to differentiate loan rates and improve the credit allocation. 


\section{A liberalized and flexible exchange market is necessary for the conduct of} monetary policy by reducing PBC's liquidity management challenges. The current high levels of foreign currency intervention require significant sterilization efforts. In addition, the perception of a one-way bet on the currency provides incentives for capital inflows that serve to complicate financial market outcomes. Moving to a more flexible exchange market would reduce the financial stability risks associated with cross-border flows and transactions; lessen the liquidity management challenges faced by the PBC; and give greater scope for independent use of indirect instruments of monetary policy. These measures would require the strengthening of market and systemic risk monitoring, and cross-border regulation and supervision.

\section{Bolstering FinAnCial SeCtor Oversight}

53. An assessment of the regulatory and supervisory framework (Table 8) reveals a high degree of adherence to international standards, but challenges remain. ${ }^{6}$ The challenge is to increase its efficiency, quality, and responsiveness. The appropriate balance has to be struck between the degree of regulatory control and the need to enable useful innovation and development of the financial system. A central theme of the assessments is to improve operational autonomy of the regulators, upgrade skills and risk monitoring capabilities, increase resources, and strengthen interagency coordination.

\section{China's sector-based regulatory and supervisory framework demands a high} degree of coordination to limit supervisory "blind spots." There is a need to develop a framework for regulation and supervision, by a single entity such as the PBC, of FHCs including industrial conglomerates investing in financial firms. The PBC has been authorized by the $\mathrm{SC}$ to draft administrative rules working with the three other regulatory commissions. In the interim, acquisition of a regulated institution should be approved by the relevant regulatory commission responsible for the underlying financial institution. In addition, the regulatory policies applying to the shadow banking system need to be clarified (Table 9). Interagency coordination arrangements among the PBC and three commissions backed by memoranda of understanding for information sharing need to be strengthened along with the removal of any legal restrictions on such sharing.

\footnotetext{
${ }^{6}$ This section should be read along with Annexes I to V containing the Reports on the Observance of Financial Sector Standards and Codes.
} 
Table 8. China: Financial System Architecture

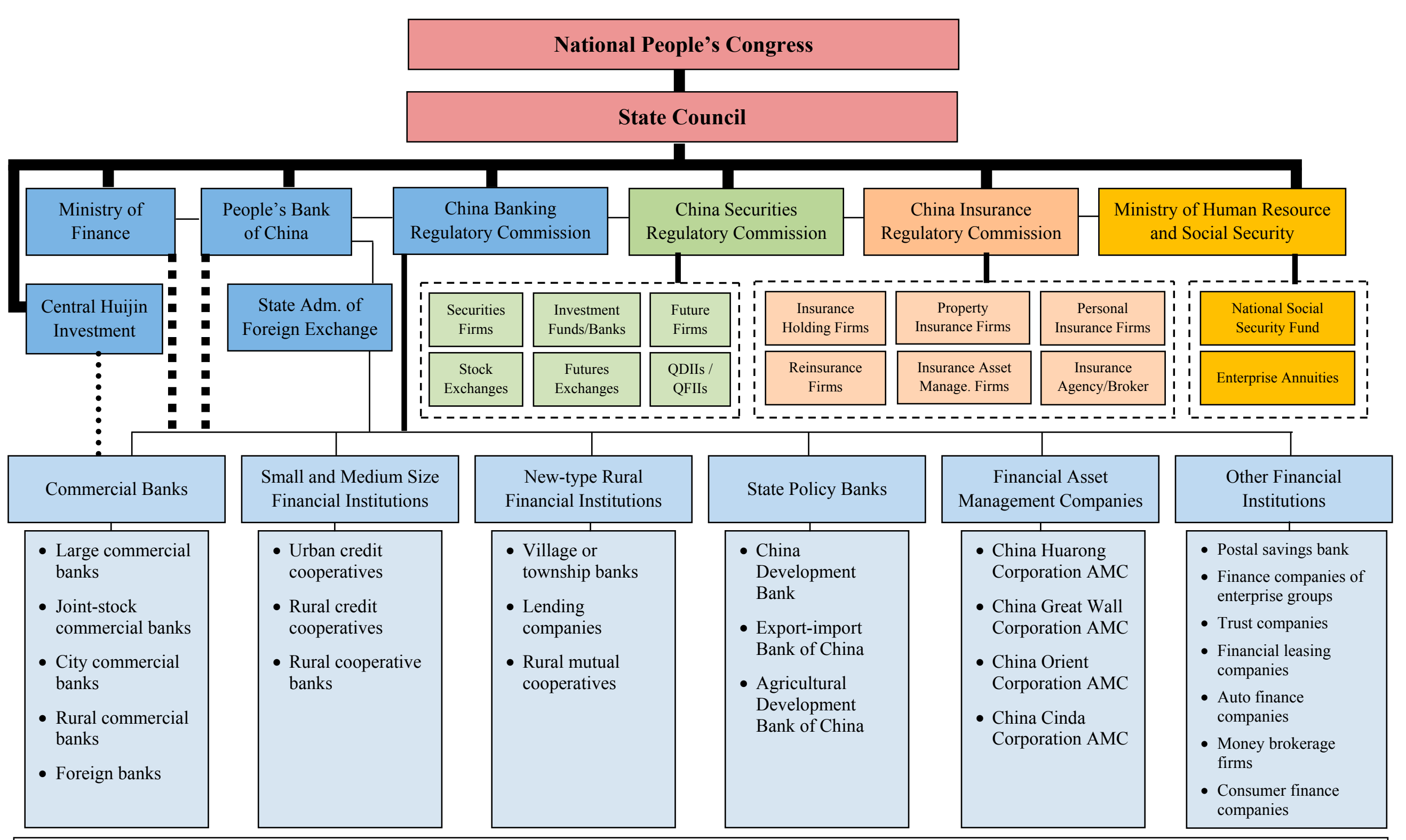

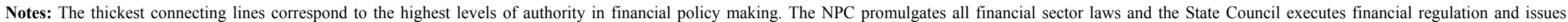

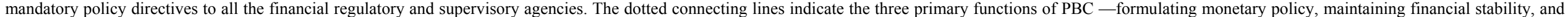

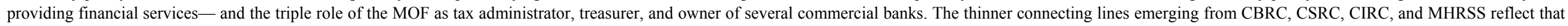

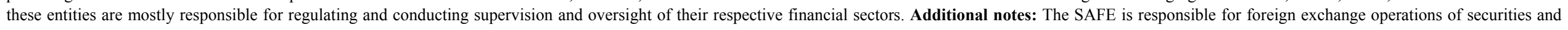

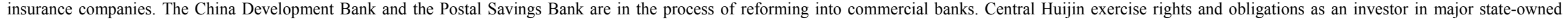
financial enterprises on behalf of the State. The National Social Security Fund has also a dual role as an institutional investor and a stakeholder in some of the largest commercial banks. 
Table 9. China: Shadow Banking

\begin{tabular}{|c|c|c|c|}
\hline Category & Financial institutions & Registration & Investigators/Regulators \\
\hline \multirow[t]{2}{*}{ Informal financial sector } & $\begin{array}{l}\text { Pawn shops, credit guarantee } \\
\text { companies, micro-finance } \\
\text { companies }\end{array}$ & Local governments & $\begin{array}{l}\text { Investigated by the PBC, CBRC, and the } \\
\text { Ministry of Public Security. In addition, } \\
\text { Financing Guarantee Regulatory Inter- } \\
\text { ministerial Joint committee led by the } \\
\text { CBRC is responsible for making the } \\
\text { regulation and policy of credit guarantee } \\
\text { institutions, providing guidance and } \\
\text { conducting coordination. The local } \\
\text { government is responsible for the } \\
\text { supervision including licensing, on-site } \\
\text { examination and off-site surveillance. }\end{array}$ \\
\hline & underground intermediation & No & $\begin{array}{l}\text { No regulators, although the PBC } \\
\text { implements survey or inves tigation } \\
\text { occasionally. }\end{array}$ \\
\hline Private equity & $\begin{array}{l}\text { Estimated 3,500 PE funds have } \\
\text { been established with assets of } \\
\text { around RMB900 billion as of mid- } \\
2010 \text { of which around } 70 \text { per cent } \\
\text { is funded from overseas }\end{array}$ & $\begin{array}{l}\text { Industrial and Commercial } \\
\text { Bureau }\end{array}$ & $\begin{array}{l}\text { The PE investment is governed by rules } \\
\text { and regulation issued by both NDRC } \\
\text { and MOC, whereas the CSRC performs } \\
\text { survey and collects data of PE funds. In } \\
\text { addition, some PE funds are not yet in } \\
\text { regulators' radar screen. }\end{array}$ \\
\hline $\begin{array}{l}\text { Wealth management } \\
\text { products }\end{array}$ & $\begin{array}{l}\text { Estimated } 7,049 \text { Wealth } \\
\text { Management products were } \\
\text { outstanding at the end of } 2010, \\
\text { totaling RMB } 1.7 \text { trillion, and } 124 \\
\text { banking institutions were involved } \\
\text { in the practice. }\end{array}$ & CBRC, CSRC, and CIRC & PBC, CBRC,CSRC, and CIRC \\
\hline
\end{tabular}

Sources: The PBC; CBRC; CSRC; NDRC; and IMF staff.

Note:(1) According to the FSB definition, shadow banks are those entities that engages in credit creation and maturity/liquidity transformation outside the banking system and that have an element of leverage, and that includes MMMFs, finance companies, $A B C P$ vehicles, SIVs etc. Due to limited data, this table does not include these entities. (2) This table only includes those that are identified by the authorities (informal financial sector and private equity) and those that are taken as shadow banks by the FSAP team (trust companies and wealth management products).

\section{A. Commercial Bank Regulation and Supervision}

55. The CBRC has a clear safety and soundness mandate. However, its operational autonomy is often undermined by the use of commercial banking system for development purposes. The CBRC has made strides in improving its framework for supervising commercial banks and emphasizing prudential goals. Nonetheless, it will be important to ensure the agency's ability to pursue its mandate is unencumbered. This will be facilitated by ensuring more stable resourcing arrangements that permit greater flexibility in building up a skilled and professional staff and continued commercialization of the banks.

\section{The legal and regulatory framework for banking has been brought closer in line} with international standards, but gaps remain. There is no legal requirement to be informed of changes in indirect control and to identify ultimately beneficial owners and clients of banks. Complex structures should be prohibited where consolidated supervision may not be possible. Rules for identifying related parties and rules underpinning bank resolution need to be strengthened. The prudential regime for asset classification and 
provisioning works well, but there are limitations in actual bank practices. Minor deviations from the Basel I framework ${ }^{7}$ may potentially overstate bank capital in the future.

57. Banks' risk management techniques and practices need to be upgraded. Large banks have built their risk management systems around simple yet conservative regulatory metrics and techniques but systems in some of the smaller banks need to be strengthened. All banks will need to update their risk management practices to keep pace with the ongoing market orientation and increasing international presence. While the major banks are developing more granular two-dimensional classification systems, their uses in risk differentiation and loan pricing is currently limited. The strong dependence on collateral and the lack of forward-looking valuation practices need to be addressed to mitigate credit risk and pro-cyclicality in lending (Figure 31). The liquidity and market risk management framework works efficiently in the current environment, but may be inadequate as the market configuration and banking conditions change. Implementing comprehensive, enterprise-wide risk management should be a top priority for the major banks. Country and transfer risk management guidance has only recently been consolidated, and its implementation has to be strengthened in view of increasing international exposure and presence. Operational risk management processes need to be strengthened by the small and medium-sized banks.

58. The risk management framework of banks is hampered by the current macroeconomic and institutional environment. Effective credit risk management in banks is discouraged by the implicit backstop of the state for their credit exposures. Banks' credit risk strategies are dominated by loan growth guidelines, and both bank risk management and supervisory assessments focus more on NPL ratios than on forward looking assessments of credit risk.

\section{B. Securities Intermediaries and Securities Market Regulation}

\section{While the CSRC has taken an active and strategic approach to regulate} securities markets, the legal and regulatory system needs improvement. Similar to other commissions, the CSRC is not operationally autonomous given the state's role in staff appointments and its influence over CSRC's operating structure. The CSRC needs greater budgetary flexibility to acquire qualified experts in an environment of rapidly growing markets. The accounting and auditing profession has made great strides in a short time frame in auditing listed companies and this needs to develop further. The newly introduced riskbased net capital rule should be monitored to ensure that it captures all risks. While there are adequate provisions for dealing with failed intermediaries, the threshold for action should be lowered to allow for early intervention.

\footnotetext{
${ }^{7}$ These deviations are currently not material and are offset by the higher minimum requirement.
} 


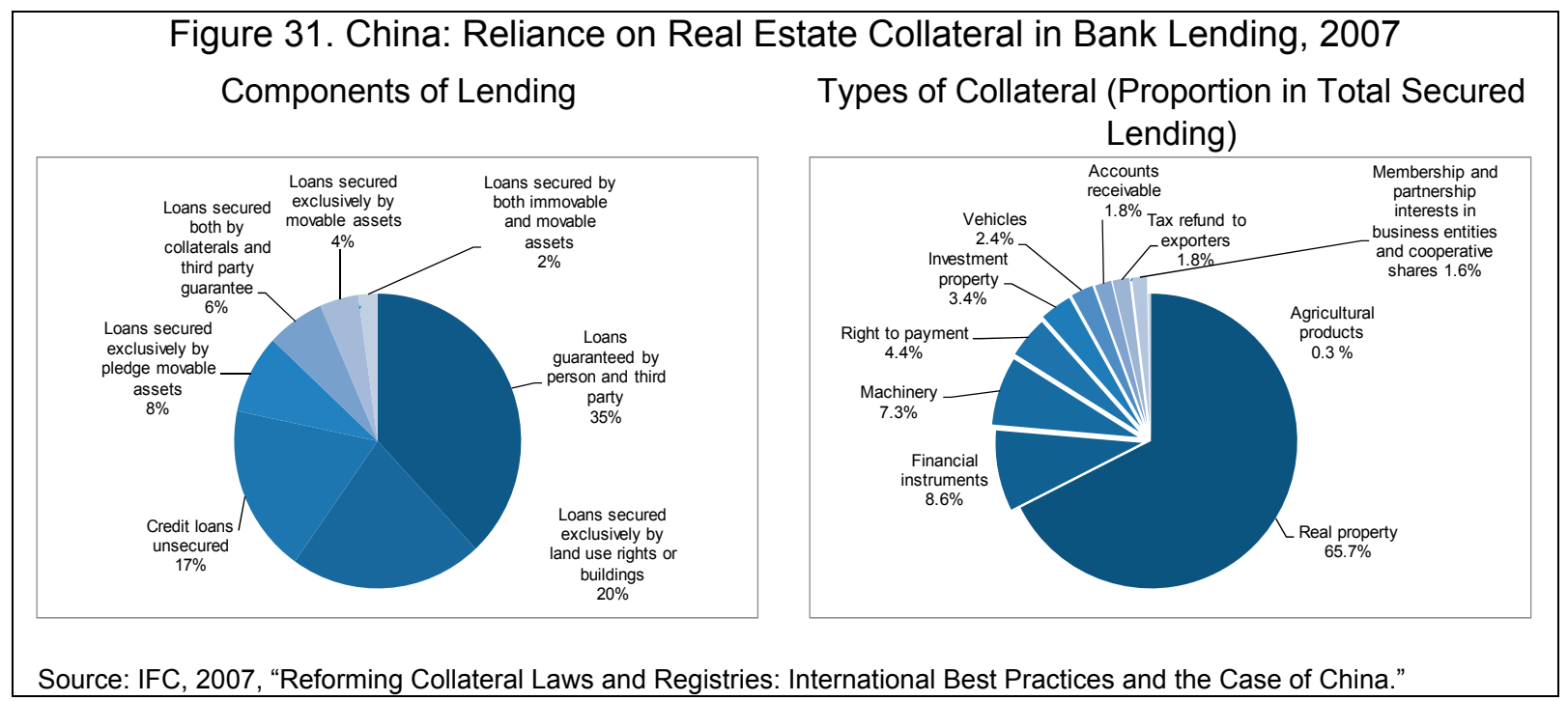

60. To bolster oversight, it would be beneficial to introduce a formal program of regular comprehensive on-site inspections of the exchanges. Stronger emphasis is needed on illegal investment activities and monitoring of hedge funds and private equity funds. Implementation of the "know-your-client" rules that require securities and futures companies to maintain comprehensive records of customers' identity, transaction records, and account data could be more carefully monitored to ensure that they result in investors making more informed decisions.

\section{Insurance Regulation and Supervision}

\section{The CIRC has a comprehensive supervisory framework in place but the} solvency regimes need to be strengthened. The minimum solvency margin should be riskbased. The continued issuance of new business by companies operating below the 100 percent solvency level is undesirable. Explicit and clear regulation is needed for facilitating the exit of insurance companies from the market via policy liability run off or portfolio transfers. Off-site monitoring could be strengthened through reinstatement of the early warning ratios previously required in insurer returns.

62. The developmental mandate for the CIRC should focus on its broad public good nature as a regulator to ensure safe practices. The current prescriptive, rules-based system, and close monitoring of insurance company activities on a monthly basis place a strong burden on staffing, and should be reconsidered. As the market and the newly introduced risk-based supervisory regime mature, the CIRC should move away from its current direct involvement in insurers' product, distribution, and investment strategies. CIRC's staffing levels need to be reinforced with suitably skilled personnel in key operational areas. 


\section{UPGRADING THE FINANCIAL INFRASTRUCTURE AND LEGAL FRAMEWORK}

\section{A. Payment and Securities Settlements Systems}

\section{The assessments of the High Value Payment System and securities and} derivatives settlements systems suggest broad compliance with international standards but identify room for improvement in several areas. The $\mathrm{PBC}$ has carried out a comprehensive reform of the China National Payments System. Going forward, the authorities should ensure that the legal framework gives full protection to payments, derivatives, and securities settlement finality. The PBC should clarify in detail its policy stance in payment system oversight and determine the scope, major policies, and instruments of the function. It should also clarify the criteria for determining the systemic importance of a system, and strengthen institutional arrangements and cooperation in the payment system arena. A more proactive oversight by the PBC over the China Foreign Exchange Trade System is advisable.

\section{B. Legal and Regulatory Structure}

64. A "stock-take" of the gaps, overlaps, and clarity in the body of laws governing the financial sector is necessary (for a partial overview, see Table 10). While the rule-based approach to regulation has been appropriate for China thus far, China would benefit from gradually applying a more principle-based approach in the formulation and implementation of laws to deal with increasingly complex and new issues.

\section{Table 10. China: Legal and Regulatory Structure for Selected Financial Products}

\begin{tabular}{|l|l|l|l|l|}
\hline Products & Issuers & Regulators & Laws and regulations & Tasks \\
\hline Mutual funds & $\begin{array}{l}\text { Fund management } \\
\text { companies }\end{array}$ & CSRC & Securities Investment Fund Law & Approval \\
\hline $\begin{array}{l}\text { Collective investment } \\
\text { plans }\end{array}$ & Securities firms & CSRC & $\begin{array}{l}\text { Trial Provisions on the Client Asset } \\
\text { Management Business of Securities } \\
\text { Companies }\end{array}$ & Filing or Approval \\
\hline $\begin{array}{l}\text { Collective wealth } \\
\text { management products }\end{array}$ & Commercial banks & CBRC & $\begin{array}{l}\text { Interim Measures for the Administration of } \\
\text { Commercial Banks' Personal Financial } \\
\text { Management Services }\end{array}$ & $\begin{array}{l}\text { Registration and } \\
\text { filing }\end{array}$ \\
\hline Trust plans & $\begin{array}{l}\text { Trust investment } \\
\text { companies }\end{array}$ & CBRC & $\begin{array}{l}\text { Notice on Relevant Issues concerning } \\
\text { Further Regulating the Trust Plans of } \\
\text { Assembles Funds }\end{array}$ & $\begin{array}{l}\text { Registration and } \\
\text { filing }\end{array}$ \\
\hline $\begin{array}{l}\text { Unit-linked insurance } \\
\text { products }\end{array}$ & $\begin{array}{l}\text { Insurance } \\
\text { companies }\end{array}$ & CIRC & $\begin{array}{l}\text { Provisional Measure for the Administration } \\
\text { of the Investment-linked Insurance }\end{array}$ & Approval \\
\hline
\end{tabular}

Sources: CBRC; CIRC; and CSRC.

65. The legal framework for consumer protection needs to be clearly enunciated, advocated, and implemented. Consumer protection must be strengthened not only in terms of courts' capacity to enforce contracts but also in empowering consumer organizations to play an effective role, enhancing personal data and privacy protection in the law as well as requiring market practices and codes of conduct to be in place. 
66. The framework for creditors' rights also should be reviewed to provide for efficient and effective exit mechanisms. Detailed laws concerning the insolvency of financial institutions have not been developed for some sectors (e.g., insurance sector). Measures are needed to provide for a continued training of judges in principles of insolvency law as well as in the specifics of the Enterprise Insolvency Law and other relevant judicial interpretations.

\section{Market Integrity}

67. The June 2007 Financial Action Task Force (FATF) mutual evaluation report indicated that China made significant progress in implementing its AML/CFT system, but it also highlighted important shortcomings. ${ }^{8}$ The AML/CFT system has since been strengthened, including through legislative changes to bolster preventive measures, notably in the areas of customer due diligence and suspicious transaction reporting. However, two significant shortcomings remain. First, Chinese law and practice provides limited ability for authorities or financial institutions to have access to the identity of the beneficial owners of legal persons. Second, preventive measures have not been extended to the majority of the non-financial businesses and professions designated by the FATF Recommendations. Deficiencies also remain with respect to the criminalization of self-laundering, and the freezing of terrorist assets. In addition, there is a need to improve information sharing and coordination arrangements among the PBC and other agencies on AML.

\section{Broadening FinanCial MARKETS ANd SERVICES}

\section{A. Fixed Income Markets}

68. The incentive for banks to use fixed income instruments to manage their balance sheets has been held back by partial interest rate liberalization. The absence of marketbased funding and dominance of lending activities act as disincentives for banks to become active in asset liability management to hedge mismatches in their balance sheet. In addition, guaranteed interest margins reduce banks' incentives to engage in fee-generating businesses in the capital market. The regulatory and operational repo market framework would need to be upgraded to increase market liquidity, enhance risk management, and reinforce the money and bond market nexus.

\section{Steps should be taken to ensure regulations of fixed income markets and} products are consistent, and clearly communicated to the market. Respective roles of three agencies (PBC, National Development and Reform Commission (NDRC), and CSRC), particularly in the corporate bond market, should be further clarified. Equivalent regulations should apply to similar types of participants even when coming under different regulators. A

\footnotetext{
${ }^{8}$ The June 2007 report is the latest available comprehensive AML/CFT assessment of China. For the full text, see http://www.fatf-gafi.org/infobycountry/0,3380,en_32250379 $32236963 \quad 1 \quad 70342 \quad 43383847$ _ $1,00$. html.
} 
possible option that would support existing market practices would be to delineate a division between wholesale and retail markets and divide regulatory responsibilities between the PBC and CSRC, respectively.

70. A more proactive and sustained benchmark-building strategy is required across all maturities of the yield curve. Currently, the MOF's treasury securities share the risk-free fixed income markets with the PBC bills in the short-to-medium terms and with the more liquid policy bank bonds in the medium-to-long term (Figure 32). There is a need to improve debt issuance strategy through the further strengthening of coordination between the MOF and PBC. To limit the impact of the PBC's liquidity management activities on the yields in the MOF issuances, the PBC should seek to limit the issuance of its paper to the short end of the yield curve. Longer term liquidity withdrawal could then

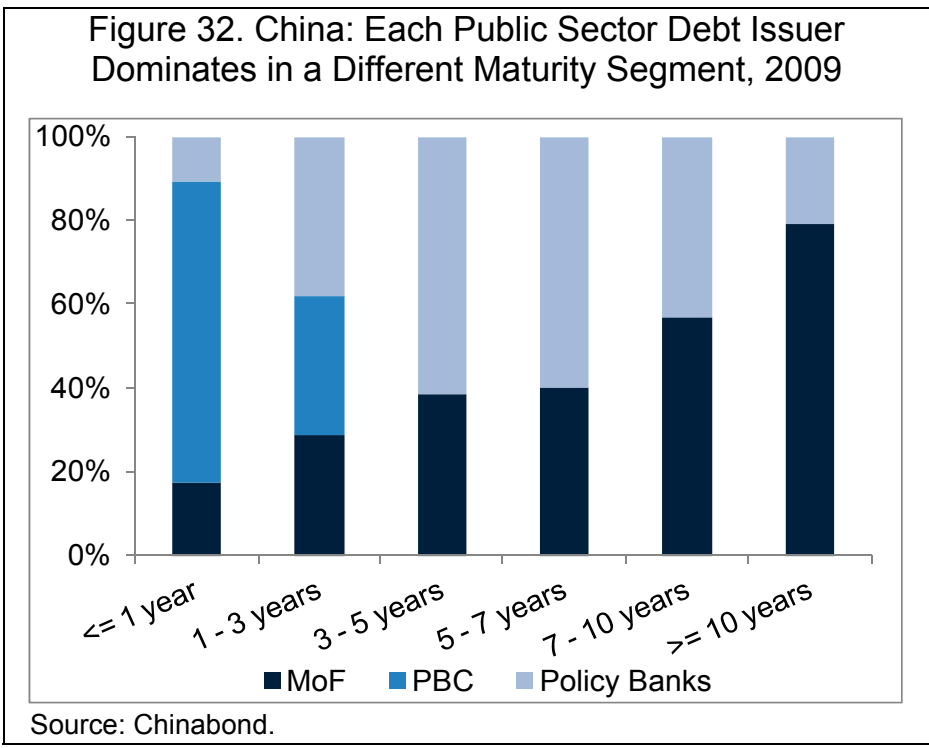
be undertaken by rolling over these securities, or by PBC undertaking longer-term repo operations.

\section{The development of a proposed sub-national debt market where local} governments can issue debt is a welcome step but carries associated risks. In the absence of a proper medium-term fiscal framework, debt sustainability analysis (DSA), and a medium-term debt management strategy (MTDS), debt issuance by provincial government could rapidly become a contingent liability and adversely affect the development of the national fixed income market. Timely and adequate data will need to be provided on projects for which bonds are issued to help investors assess risks. The role of rating agencies would also have to be properly defined so that a consistent bond rating methodology could be applied.

72. In the corporate bond market, developing a segment that accommodates lower, yet credible credit rating standards might allow enterprises, currently excluded from the securities markets, to access corporate debt markets. Easing the legal limit of 40 percent of net assets on bond issuance will enable a more extensive use of direct funding to all corporations. In addition, upgrading links between CCDC and SD\&C to enhance connectivity between IBBM, SSE, and SZSE, support further development, and contribute to efficiency in all three markets. 


\section{B. Equity Markets}

\section{Further development in equity markets hinges on addressing legacy issues and}

better servicing the needs of SMEs. Residual legacy constraints and anomalies relating to nontradable, "A" and "B" shares should be addressed and the current free float of shares in public companies expanded. The build-up of a smooth conduit between the private and public offer segments is critical as this could make sustainable funding options available to SMEs and increase the presence of private companies on the exchanges. Launched in 2009, the Growth Enterprise Board is expected to provide exit channels to private financing.

\section{Insurance Sector}

74. There is a need to achieve a better trade-off between scale and competition. Most of the insurers licensed in the past decade continue to lose money (Table 11). Introducing more comprehensive risk-based capital requirements and requiring shareholders to achieve these over a suitable period is recommended. Strengthening the actuarial oversight of nonlife claims provisioning and clarifying the voluntary wind up and exit rules and processes are also desirable steps. The fact that staff salaries and benefits and secured borrowers rank ahead of life policyholders in the event of a wind up is contrary to international best practice. Other strategies could involve taking action to enable insurers to generate more stable but higher returns to equity.

Table 11. China: Insurance-Operating Performance by Size, 2009 (In Percent)

\begin{tabular}{lccc}
\hline & Op. Return on Assets & Combined Ratio & ROE \\
\hline Life & & & \\
Top 10 & 6.3 & & 18.4 \\
Next 10 & -1.1 & & -11.4 \\
Remainder & -2.6 & & -11.4 \\
& & & \\
Multi Line Non Life & & 101.7 & 11.4 \\
Top 10 & & 117.7 & -5.9 \\
Next 10 & & 122.0 & -5.3 \\
Remainder & & & \\
\hline
\end{tabular}

Source: Insurance Yearbook 2010.

\section{Pension Sector}

75. The emphasis of the pension system should be on the funded component. Pension reserves of the first pillar remain invested in inefficient portfolio. Capital protectionenterprise annuity system's most popular investment strategy - will not be able to generate sufficient returns to obtain reasonable pensions in the future. Longer-term horizon strategies require greater allocations in equity and longer-term bonds than the ones that are currently in place. Investment regulation should discourage short-term evaluation of performance and 
focus on the long-term actuarial objectives of the fund. Given China's strong culture of saving, one option is to expand the scope of personal defined-contribution pension plans by designing attractive personal income tax incentives or matching fund contributions for low income individuals.

\section{E. Access to Finance}

\section{The approach thus far in promoting rural and MSE finance may need a} paradigm shift. An evaluation of the existing government programs is needed to determine their effectiveness in promoting rural and MSE finance and the government should formulate an integrated and coherent rural and MSE finance strategy. Several steps can be taken to substantially broaden access to finance. Government should continue to reform rural credit cooperatives to enhance their efficiency and sustainability as commercial providers of financial products and services. It is also important to complete the reform of the Postal Savings Bank by optimizing equity ownership, overhauling the bank to become a corporation, and building effective corporate governance.

\section{Sequencing Financial Reforms}

77. Further financial reforms are crucial for sustaining China's growth and will need to be carefully crafted to limit risks to financial stability. Country experiences have shown that while financial liberalization can spur growth and development, it also entails risks if not properly designed and composed. Given the breadth of China's envisaged reform agenda, it is important to devise a strategy that anticipates the complications and uncertainties that may arise, and provide guidance on how best to arrange the policy measures without delaying necessary changes. Reform without the necessary preconditions in place can be extremely perilous for financial stability.

78. While there is no "one size fits all" approach towards financial liberalization, some broad principles apply in the case of China (Figure 33). A key overarching precondition for a smooth transition would be to put in place a well functioning legal, regulatory, supervisory, and crisis management framework with adequate technical capacity. This is essential to monitor financial institutions and manage risks. Another precondition is an early absorption of the current liquidity overhang in the financial system to prevent an unintentional loosening of monetary and credit conditions. Reserve averaging and regular open market operations should be introduced early to help absorb some of the liquidity overhang. At the same time, greater reliance on indirect monetary instruments and more flexible exchange rate would increase the scope for macroeconomic control. 


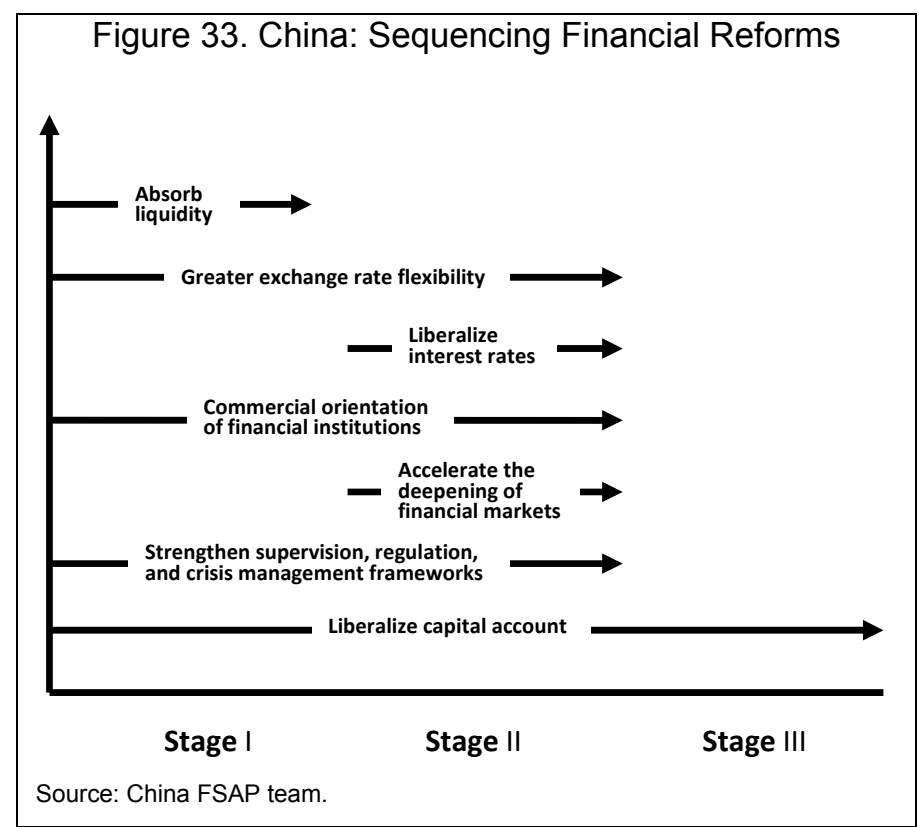

\section{A modern financial infrastructure and a more market-based financial system} will enhance a steady integration with the global financial system. The banking system needs to operate on a more commercial basis and be closely supervised to avoid overly risky behavior and an unsustainable compression of bank margins. The government would need to reorient its role in the financial system so as to reduce the incidence of direct and contingent risks on its balance sheet and remove the moral hazard problem. Alongside such improvements, the gradual liberalization of deposit and loan rates can be successfully implemented. As the banking system becomes more commercially-oriented, broader financial deepening could be accelerated without the risk of disorderly disintermediation. With interest rates set by supply and demand and monetary control exercised through shortterm policy rates, China could then move more toward full liberalization of the capital account. 


\section{APPENDIX I: STRESS TESTING}

80. The stress testing exercise was a collaborative effort between the FSAP stress testing team and a PBC/CBRC stress testing team. This was to ensure that the stress test work (i) captures the key aspects of the Chinese economy and the financial system; (ii) builds, to the extent possible, on relevant analytical work already being carried out; and (iii) establishes a coherent operational framework that the authorities could use, and build upon, following the completion of the FSAP.

81. The tests covered 5 LCBs and 12 JSCBs. Taken together, these 17 major banks accounted for about 66 percent of China's banking sector assets and 83 percent of China's commercial banking sector assets as of end-2010. The tests did not cover non-banking financial institutions. All the tests were carried out on end-2009 audited or supervisory financial positions of the 17 major banks and, for comparison purposes, top-down aggregate credit risk and real estate risk analysis was carried out for end-2008 and end-2010 positions of the same banks. In the absence of reliable market-based indicators for these banks, the approaches used in the stress tests relied on data from the banks' public financial statements, prudential reports and banks' internal data systems.

82. The exercise built on three pillars: a bottom-up pillar and two top-down pillars (Figure 34). The 17 banks selected to participate in the exercise implemented the bottom-up calculations, using the same set of shocks and assumptions. The PBC/CBRC team implemented top-down calculations on a bank-by-bank basis using supervisory data and applying an agreed methodology. Both sets of results were provided to the FSAP team at the aggregate level and by bank type. The number of banks that fall below regulatory requirements and their share in the overall banking system's total assets was also provided. The FSAP stress testing team carried out its own set of top-down calculations, based on publicly available data. The results of the three approaches were compared, analyzed, and cross-checked.

83. The tests included a range of sensitivity analyses and scenario calculations. They examined aggregate credit risk, concentration of credit risk, direct exchange rate and interest rate risks, liquidity risks, contagion effects via the documented interbank market, and the joint effect of a set of macroeconomic shocks.

\section{Sensitivity tests estimated the impact of changes in individual variables on}

banks' portfolios. In a sensitivity analysis framework, shocks are assumed to stem from a single risk factor, holding other risk factors constant. Shocks are assumed to occur instantaneously, unless indicated otherwise. The sensitivity analysis covers all positions sensitive to risk factor changes. To the extent possible, these included all long (buy) and short (sell) positions, both on-and off- balance sheet. 
Figure 34. China: Stress Testing Exercise: Three Pillars

\begin{tabular}{|c|c|c|c|}
\hline & \multicolumn{3}{|c|}{$\begin{array}{l}\text { Assumptions } \\
\text { single shocks and shock combinations } \\
\text { common for all three pillars }\end{array}$} \\
\hline & Pillar I & Pillar II & Pillar III \\
\hline Calculations by: & Individual banks & $\mathrm{PBC} / \mathrm{CBRC}$ & IMF staff \\
\hline Type of data: & $\begin{array}{l}\text { Management } \\
\text { info. system }\end{array}$ & $\begin{array}{l}\text { Supervisory / } \\
\text { /audited }\end{array}$ & $\begin{array}{l}\text { Publicly } \\
\text { available }\end{array}$ \\
\hline Aggregation: & Individual bank & $\begin{array}{c}\text { Aggregate } \\
\text { \& bank-by-bank }\end{array}$ & $\begin{array}{c}\text { Aggregate } \\
\text { \& bank-by-bank }\end{array}$ \\
\hline Types of analysis: & $\begin{array}{l}\text { Single factors } \\
\& \text { scenarios }\end{array}$ & $\begin{array}{l}\text { Single factors } \\
\& \text { scenarios }\end{array}$ & $\begin{array}{l}\text { Single factors } \\
\& \text { scenarios }\end{array}$ \\
\hline $\begin{array}{l}\text { Approaches to } \\
\text { scenario analysis: }\end{array}$ & $\begin{array}{l}\text { Combination } \\
\text { (model-based; } \\
\text { experts) }\end{array}$ & $\begin{array}{l}\text { Model-based } \\
\text { Chinese data }\end{array}$ & $\begin{array}{l}\text { Model-based, } \\
\text { Chinese \& cross- } \\
\text { country data }\end{array}$ \\
\hline Cross-checks: & Results & Results & Results \\
\hline
\end{tabular}

Source: FSAP stress testing team.

85. Credit risk was a key area of focus. The sensitivity analysis for credit risk included an aggregate shock to asset quality, and a set of separate shocks, each aiming to examine a different aspect of credit risk concentration. The aggregate test assumed an overall deterioration in asset quality. In addition, part of the exercise was carried out to pick up the differentiated risks based on the economic sectors and types of entities to which banks lend, as well as the regions in which banks concentrate their operations. However, it was not feasible to fully cover all these dimensions given data constraints. In light of this, a set of separate shocks, each run separately, covered: (i) largest individual exposures; (ii) real estate sector exposures; (iii) exposures to LGFPs; (iv) exposures to overcapacity industries; (v) exposures to export sectors; and (vi) exposures to sectors (industries) and regions with the most rapid loan growth. The equity market shock was not conducted on as banks are prohibited from directly investing in equity markets and the indirect exposure is infeasible to estimate.

86. Macro-scenario tests were a key part of the exercise. Three adverse macroeconomic scenarios were assumed: mild, medium, and severe. Based on an analysis of past growth rates of real GDP in China, as well as the experience of other countries, the 
assumed annual real GDP growth rates under the three scenarios were 7 percent, 5 percent, and 4 percent, respectively.

\section{The scenarios were calibrated with inputs from a panel of leading experts on}

Chinese economy. To arrive at meaningful scenarios combining GDP growth rates with other variables, the $\mathrm{PBC} / \mathrm{CBRC}$ stress testing team, in coordination with the FSAP stress testing team, solicited opinions from an expert panel. To increase the comparability of experts' views, and given that all the banks use GDP as one of the macroeconomic indicators, the GDP growth rate was provided to experts as a key variable for each scenario and their views were solicited on the behavior of other variables under the assumptions. Table 12 summarizes the selected macroeconomic scenarios.

Table 12. China: Macroeconomic Scenario Assumptions (Changes in Percent, unless Indicated Otherwise)

\begin{tabular}{lrrr}
\hline & Mild & Medium & Severe \\
\hline GDP & 7 & 5 & 4 \\
M2 & 14.7 & 12.4 & 10.2 \\
Real estate price & -7.0 & -16.2 & -25.9 \\
Change in benchmark interest rates for & 35 & 66 & 95 \\
lending and deposits in RMB (basis points) & & 119.6 & 123.0 \\
Real effective exchange rate index & 117.5 & 11.6 \\
\hline
\end{tabular}

Note: These are not forecasts, but assumptions about potential adverse developments in the future.

Source: FSAP stress testing team and PBC/CBRC, based on inputs from a panel of leading experts on Chinese economy. The assumptions are derived from the averages of the experts' inputs, excluding two outliers.

88. The macroeconomic scenarios were examined using both top-down and bottomup approaches. For the bottom-up exercise, banks relied on a combination of econometric models and expert-based approaches, although the exact implementation depended on the capacity of individual banks, with some having sophisticated internal models, while others relying on more basic modeling approaches or on loan officers' expert judgment. For their top-down estimate, the $\mathrm{PBC} / \mathrm{CBRC}$ team used an econometric equation estimated on recent data for China. The top-down estimate done by the FSAP team included cross-checks based on international experience. 


\section{Table 13. China: Recommendations for Improvements in Stress Testing}

- $\quad$ Conduct regular macro-prudential stress tests with participation of the major banks.

- $\quad$ PBC and CBRC to work further with banks to ensure that they improve their modeling capacity, in particular in relation to modeling impacts of macro-economic scenarios.

- Harmonize banks' approaches to stress testing, in particular for macro-scenario tests.

- $\quad$ Continue working towards integrating the various exercises for credit risk with the calculations for market risks, liquidity risk and contagion risk.

- $\quad$ Extend the stress tests beyond the 17 banks and include more off-balance sheet exposures.

- $\quad$ Improve quality of the underlying data on stress testing, in particular on PDs and LGDs.

- Strengthen the capacity for data collection.

- Incorporate into the analysis more granular data on banks' loan portfolios, by economic sector, types of counterparty (e.g., SOEs and SMEs), as well as the specific sector in which banks concentrate most of their operations.

- One sector that should be priority in this respect is real estate. Improve the data reporting systems to enable carrying out a stress test with differentiated shock sizes in different parts of the country.

- Another sector of focus should be exposures to local government.

- $\quad$ Start collecting data on banks' exposures to export-oriented counterparts.

- $\quad$ Start collecting more comprehensive data on bilateral interbank exposures, so as to carry out an improved contagion stress test.

- $\quad$ Start collecting data on banks' non-financial counterparts (firms, households). 
AnNeX: ObServance OF Financial Sector Standards ANd CODES-SumMary of ASSESSMENTS

This Annex contains the summary assessments of China's observance of international standards and codes in the financial sector.

These assessments have helped to identify the main strengths of the supervisory, regulatory, and market infrastructure framework in managing potential risks and vulnerabilities in the financial system. They also suggest areas that need strengthening and further reform.

The summaries are based on detailed assessments of the following international standards:

- Basel Core Principles for Effective Banking Supervision-by Nicholas Le Pan (World Bank consultant), Walter Yao (IMF consultant), and Aditya Narain (IMF)

- IAIS Insurance Core Principles - by Henning Göbel (World Bank consultant)

- IOSCO Objectives and Principles of Securities Regulation-by Greg Tanzer (World Bank consultant)

- CPSS Core Principles for Systemically Important Payment Systems — by Massimo Cirasino (World Bank), and Mario Guadamillas (World Bank)

- CPSS-IOSCO Recommendations for Central Counterparties - by Massimo Cirasino (World Bank), and Mario Guadamillas (World Bank)

\section{AnNex I: ObServance of Financial Sector Standards ANd COdeS-BASEl Core PRINCIPLES FOR EFFECTIVE BANKING SUPERVISION: A SUMMARY}

\section{A. Introduction}

\section{Regulation and supervision of China's banking system has made impressive} progress. Significant improvements in risk measurement and risk management have occurred. These are backed up by a regulatory system that demands high-quality capital and liquidity, often through simple and basic regulatory requirements. However, as further opening up and innovation occurs, and China's banks expand, complexity and risks will increase. The CBRC and banks must evolve quickly in the short term to be ready to meet those challenges. The framework of laws and guidance is generally of high quality, but much of it is relatively recent. Implementation by banks needs to be improved, in some cases materially. Enhanced vigilance is required by banks and the regulator to keep risks under control in China's system, in which banks are looked on by the State to be heavily, directly involved in achieving economic and social goals. The CBRC is widely-respected and has demonstrated its willingness to act in pursuit of its safety and soundness mandate. It urgently 
needs to have a plan to enhance its experience and expertise, ensure progress to date is sustainable, and needs continued support of government in that endeavor.

90. This assessment of the current state of the implementation of the Basel Core Principles for Effective Banking Supervision (BCP) was undertaken between June 7 and June 25, 2010. It reflects the regulatory and supervisory framework in place as of the date of the completion of the assessment. In line with the BCP methodology, the assessment focused more on the major commercial banks and their regulation and supervision, given their importance to the system.

\section{B. Information and Methodology Used for Assessment}

91. The assessment team reviewed the legal framework for banking supervision, held extensive discussions with the staff of the CBRC and two of its regional offices. The assessors also met with officials of the central bank - the PBC, the MoF, the National Audit Office (NAO); several commercial banks, audit firms, rating agencies, and the China Bankers Association. The team examined the current practice of on-site and off-site supervision of the CBRC. The assessment team had the benefit of working with a comprehensive self-assessment completed by the CBRC, enjoyed excellent cooperation with its counterparts, and received the information it required.

92. Reaching conclusions required judgments by the assessment team. Banking systems differ from one country to another, as do their domestic circumstances. The banking system has undergone tremendous change in China in the recent period and this process is still ongoing. The CBRC is a relatively young agency, having been created in 2003 from the PBC as part of the major banking sector reform instituted by the Chinese authorities. In addition to the strengthening of financial sector regulation and supervision, these reforms have also led to the conversion of four large state-owned banks into joint-stock companies; reform of rural credit cooperatives; restructuring of joint-stock banks and securities companies; and reform of the insurance sector.

\section{Institutional Setting and Market Structure-Overview}

93. The Chinese financial system is dominated by the rapidly-growing banking sector, with nonbank financial institutions accounting for only a fraction of the system. The banking system accounts for nearly 80 percent of the net new lending every year. China's capital markets remain relatively shallow, and over 60 percent of outstanding bonds issued by the government and the majority of the remaining being issuances by the large financial institutions, with policy banks (which are state owned and provide a range of development finance services in support of infrastructure, agricultural development, export insurance, etc.) and China Development Bank being the second largest issuers. The insurance sector, however, is rapidly growing, though, as are linkages between banks and insurance companies. 
94. Although the banking sector is extraordinarily large with assets over 200 percent of GDP the financial systems is still relatively new, simple and evolving. Key financial prices remain regulated, which insulates banks from market risk. Despite gradual interest rate liberalization over more than a decade, retail interest rates remain partly regulated - deposit rates are subject to a cap and lending rates to a floor. Banks can price lending above the floor to a degree, and do so in practice.

95. Within the banking sector, the five large commercial banks account for just over half of the banking system assets. The next Tier of banks are the joint stock commercial banks, followed by city commercial banks and rural commercial banks which have been formed by the reform of city credit cooperatives and rural credit cooperatives respectively. These are followed by deposit taking institutions such as rural and city credit cooperatives, postal savings banks, village and township banks. Despite over 200 branches and subsidiaries operating in China, foreign banks remain a small presence with assets less than 2 percent of the total. However, in recent years, overseas financial institutions have made significant equity investments in Chinese banks.

96. The prudential ratios on capital adequacy, NPLs, and liquidity, for instance, for the banking system have improved significantly. A significant amount of the bank assets represent exposures to central bank, and central and local governments, and there remains scope for further gains to be made in wider intermediation.

\section{Preconditions for Effective Banking Supervision}

\section{The legal system in China brings together a number of distinct legal traditions} within the overarching framework of a civil law system. The structure of the legal framework has undergone a series of phased transitions, first to enable complete state ownership until the 1970s, and more recently to facilitate China's move towards a more market-oriented economy within a socialist political and economic framework.

\section{In lieu of a Commercial Code, China enforces a series of commercial laws,} providing a mechanism to regulate commercial activities. In its place, the government legislated a series of distinct measures to regulate commercial relations. More recently, a number of symbolically and legally important measures have been passed, notably the Property Law of 2007, that further recognizes private property rights, as well as the Enterprise Bankruptcy Act 2007, which seeks to give greater protection to secured creditors than has otherwise been accorded under Chinese law (e.g., by giving secured creditors priority over worker's wages on winding up). There is little data with reference to enforcement of bank debts, but available data suggests that that enforcement of contracts in general by Chinese courts has improved dramatically in some urban centers to keep pace with economic reform. 
99. China is gradually building up an infrastructure that promotes and supports market discipline. The Company Law, Law on Commercial Banks, Law on Banking Regulation and Supervision, Securities Law, and Insurance Law all provide specified requirements on information disclosure. The CBRC was established in 2003 as a stand-alone prudential authority and is widely credited with having made significant achievements in its short existence, having been the key driving force in improvements in risk management, corporate governance and internal control and disclosure in Chinese banks. In practice, all banks are required to publicly disclose their information in their annual reports, including audited financial statements, corporate governance, capital adequacy, risk exposures, risk management strategies and practices, and other quantitative and qualitative information. In addition, the listed banks are subject to information disclosure requirements set forth by the CSRC. Considerable efforts have also been made by the financial regulatory agencies to improve the corporate governance of financial institutions. Under corporate governance rules banks have a dual board. There is a full-time board of directors. There is also a supervisory board which oversees the performance of the board and senior management. It is not involved in strategy formulation, but receives reports from audit and control functions to ensure that the board and management are performing as expected and following the boardapproved strategy.

100. Since 2005, China accounting standards have substantially converged with International Financial Reporting Standards (IFRS) and International Standards on Auditing, respectively. In February 2006, the MoF which sets accounting and audit standards promulgated the Accounting Standard for Business Enterprises, which replaced the previous China Accounting Standards and became effective in January 2007. The new accounting standards consist of one basic standard and 38 specific standards, which have substantially converged with the international standards and were recognized by the International Accounting Standards Board (IASB). Currently, all listed companies, financial institutions and non-listed large and medium-sized enterprises have adopted the new accounting standards. Also, in 2006, the MoF issued a new set of auditing standards; one review engagement standard; two other assurance engagement standards; two related service standards; and one quality control standard, which have also converged with the international standards and were thus recognized by the International Federation of Accountants.

101. Accounting and auditing professions have grown considerably, though certain areas need improvements. Over the past three decades, China's Certified Professional Accountant (CPA) industry has been growing steadily. Currently, there are more than 7,000 accounting firms registere in China, with more than 97,000 CPAs in practice. The MoF is responsible for regulating the accounting and auditing professions, with the regulatory responsibilities including qualification review and approval, professional performance supervision, and overseeing the activities of relevant industry associations. Coverage of bank audits is adequate, as the $\mathrm{CBRC}$ requires banks with total assets exceeding RMB 1 billion to receive financial statement audits; however, some weaknesses exist. Earlier reports and 
market participants interviewed by assessors have cited that the audit quality of smaller accounting firms needs improvements. The credibility of the audit profession would be enhanced as the authorities implement the standard auditor independence regulation recently incorporated in the China Code of Professional Ethics for Certified Public Accountants and increase their oversight of the profession by performing regular and more frequent review of accounting firms' audit quality.

\section{In recent years, the $\mathrm{PBC}$ has carried out a major reform of the National} Payment System (NPS), by launching the China National Advanced Payment System (CNAPS). The CNAPS consists of the High Value Payment System (HVPS) and the Bulk Electronic Payment System. The HVPS is a real time gross settlement systems and mainly used for large value transfers. It is used to provide fast, efficient, secure and reliable payment clearing services to banking institutions, private and public entities and financial markets. Currently the system has more than 1,600 direct participants. China is also evolving to a more intensive use of non-cash payment instruments, especially cards.

103. China does not have an explicit public safety net in the form of deposit insurance but is considering its introduction. Given the high level of government ownership of banks, there may be a public perception that the State would stand behind all depositors in the case of a closure. The central bank has authority to make lender of last resort loans to banks.

\section{There have been restructurings of several banks with serious financial}

difficulties. These have tended to involve "whole bank," going concern solutions whereby another bank has been convinced to take over the assets and liabilities of the problem institution (or at least the deposit liabilities). There is no explicit resolution framework for such eventualities but the authorities have demonstrated the ability to achieve such solutions using the existing bankruptcy and other laws. There are several aspects of the bankruptcy laws that deserve consideration in order to increase systemic protection and reduce contagion risk in the event of bank failures. The authorities should consider whether a separate insolvency regime for banks may serve them better especially given the increasing internationalization of the large banks and the current global focus on developing more compatible cross-border resolution frameworks.

\section{E. Main Findings}

\section{Objectives, independence, powers, transparency, and cooperation (CP 1)}

105. The objectives and responsibilities of authorities involved in banking supervision are clear. CBRC's mandate has enabled it to focus on a single mission of safety and soundness and that has helped it become a high-quality organization. Using this mandate, CBRC has been very successful in articulating to banks and the public the need to achieve 
both safety and soundness and the needs for economic and social progress through the banking system. Indeed, safety and soundness contributes to development goals. CBRC has pushed for high-quality risk management by banks as part of their delivering on economic and social objectives. Following its mandate, and as a result of observed or potential deficiencies in risk management practices, CBRC has recently introduced a range of prudential measures, including more stringent credit risk management of loans to local government platforms and real estate lending. It has also successfully pushed banks to hold more capital and more provisions in the face of rapid loan growth as part of the stimulus package.

106. The potential conflict between safety and soundness objectives and other objectives exists in many countries but can be more acute in China because of the predominant use of the banking system, much of which is state owned, to achieve economic and social goals. The $12^{\text {th }}$ plan for the financial sector being developed as part of the $12^{\text {th }}$ Five-Year economic plan under the SC for the NPC should reinforce the importance of safety and soundness and CBRC's early intervention to resolve potential problems before they become serious. It should also make a priority for continued improvement in banks' risk management with a focus on assuring all banks, not only the most advanced, make needed improvements and ensure that improvements already made are well entrenched in their operations. The importance of safety and soundness and high quality risk management to economic and social objectives should be explicitly recognized by the authorities. Current CBRC leadership has played a key role in promoting prudential goals and dealing with issues of possible conflict of safety and soundness objectives with national economic policies. It will be important to continue this.

\section{The arrangements for resourcing in CBRC leads to potential independence} issues, and hampers effectiveness, particularly as banks become more complex and innovative, and expand abroad. So does the potential ability for the SC to override CBRC rules, though this has never been exercised. The CBRC law mandates it to take decisions free from interference from any party, and CBRC reports that no interference has occurred since its creation. However the existing arrangements could be problematic in future. The laws, rules and guidance that $\mathrm{CBRC}$ operates under generally establish a benchmark of prudential standards that is of high quality and was drawn extensively from international standards and the BCP themselves.

108. However, much of the guidance is relatively new and the issues raised in assessment of various CPs are often ones of better implementation. In many ways, the strength of CBRCs regulation to date lies in the deliberately simple, conservative approach it has taken, often relying on specific prudential ratios that banks must meet. This is true for liquidity and for capital adequacy, for example. The challenge going forward is that this approach, by itself, will not be sufficient as markets and banks evolve. CBRC is well governed within the constraints it faces and has steadily and materially increased its 
transparency. There is need for: more forward resource planning; an urgent governmentsupported strategy for material upgrading of skills especially specialist skills; and more flexibility in budgeting and pay to support this strategy and attract and retain talent. CBRC's performance reporting has greatly improved but more is possible.

109. The legal framework for banking supervision has been revised to incorporate legislation, guidelines and rules (which all have legal standing) based on international standards. CBRC has authority to take a wide range of corrective and remedial actions, and is clearly willing to use them. CBRC staff is legally protected from the consequences of acts committed in good faith. CBRC also has the legal authority to share information with other regulators, domestically and internationally and does so through networks of Memorandum of Understanding (MOUs).

\section{Licensing and structure (CPs 2-5)}

\section{China defines the permissible activities of banks and operates an extensive} licensing and approval process for banks. Considerable staff is involved in approving new institutions, new branches or sub-branches of existing institutions, new products, as well as changes in ownership. Fit and proper criteria apply to board and senior management, but also extend to many other positions in a bank. The use of the name "bank" is properly controlled and shell banks are not permitted. Minimum capital requirements to start a new bank depend on the type of bank and are in line with or higher than international norms.

\section{CBRC implements an appropriate approval process for changes in ownership} and major acquisitions. However, the Chinese system is evolving from a system of state ownership to more private ownership, opening up the possibility of more complex ownership structures for banks. In this context CBRC's lack of legal authority could impede their ability to review beneficial owners or indirect changes of control. They report that they do usually get information on beneficial/indirect owners through the direct acquirer or through other indirect means. The assessment team did not come across instances where supervision effectiveness has been compromised because of this issue but this legal authority should be bolstered. Other CBRC rules that also involve potentially more complex bank ownership structures (e.g., related party rules) should also be reviewed to ensure that such structures are clearly covered by the rules. Investments by banks, including in overseas branches, require approval as part of the general approval system. While banks are generally prohibited from investing in nonbank activities, in the recent past exceptions have been permitted for investment in financial leasing and asset management. Bank-insurance and bank-fund management company investments have not been allowed until recently, when four crossownership pilots are in process. In those cases CBRC imposes firewalls between the banks and the other entity. Among other considerations, there are also explicit provisions that these pilots must earn at least average industry returns or they are to be dissolved. 


\section{Prudential regulation and requirements (CPs 6-18)}

112. The capital adequacy rules are based on Basel I. Basel II is being introduced over the 2011-2013 period for six banks that must adopt it on a mandatory basis. Some other banks have also decided to adopt it on a voluntary basis. Basel II was not formally assessed as it was not in place at the time of the mission. The choices China has made in implementing Basel I have generally been conservative, and result in Chinese banks uniformly having capital ratios above the Basel minimum. Banks' capital is composed primarily (approximately three-quarters) of high-quality core capital. The minimum required capital is 8 percent. Recent measures have raised expected capital ratios above the Basel minimum to 11.5 percent for the five major banks and 10 percent for all other banks, as part of a move to counter-cyclical buffers. How these buffers will work in a counter-cyclical way has not been specified. CBRC needs to review and communicate what its ongoing expectations are for banks to hold capital above the minimum and the criteria it will use to decide how to alter the buffer. There are a few aspects of the rules that are less conservative than the Basel I provisions, that should be reviewed.

113. Risk management is evolving in Chinese banks. CBRC has played a major role in the significant and impressive improvements that have occurred. Less than fully compliant ratings in certain areas in this assessment generally reflect deficiencies in the legal framework, which can be amended, or that banks have yet to fully implement CBRC guidance. $\mathrm{CBRC}$ itself is performing excellently in a challenging and fast-changing environment. It is on the right track with its reform agenda and needs to persevere in a sustained way in its current direction. It will need the full support of all other parties in the government to succeed in the goals it has set for itself. Most major banks have developed risk management systems for each of the major individual risks they face, though improvements are required in certain cases. CBRC guidance is generally of high quality and was often developed directly from Basel documents. Framework guidance in some risk areas is relatively new, with some being issued as recently as the last half of 2009. A period of settling in is required for effectiveness to be enhanced, for those banks who are not the most advanced to catch up, and for CBRC to ensure that all banks have risk management systems commensurate with the risks they are assuming.

114. The new risk governance, risk measurement and risk management systems have not been tested under stress and some areas for material improvement are clearly evident. Board-approved strategies are often too focused on target loan growth in various sectors and not enough on targeted risk measures linked to the bank's own risk systems, as opposed to regulatory requirements. Comprehensive, enterprise-wide risk management that takes account of interactions between risks in measuring, managing and stress testing, and that relates capital to risk is at an early stage in some banks, including some major banks. For many banks the priority is not to move to this stage quickly, but rather to ensure that a sound 
risk management framework is fully in place, imbedded in their culture and group-wide operations, and sustainable. While much of banking in China is deposit taking and lending, major Chinese banks are some of the largest in the world, and the Chinese lending market is complex by virtue of its scope and diversity, and banks are getting into new areas of lending and other activities. So risk management needs to be commensurate with these realities. China is considering introducing explicit deposit insurance arrangements. It will be important as it does so that it carefully considers the roles of the various organizations in a resolution.

\section{Credit risk is the most important risk facing Chinese banks and will remain so}

for some time. It has received the most focus by banks and CBRC and is generally well controlled. However there is intense focus on NPL experience by banks, policy makers and by a considerable part of CBRC staff. This is understandable given the serious bad-loan experience in the early part of the decade. But this almost sole focus sometimes is at the expense of attention to other early, forward-looking measures of credit risk that need to be responded to. Senior leadership in CBRC and some banks understand the need for forwardlooking judgment but assessors sensed that this message has yet to flow fully through their organizations. The rules and practice for problem assets, provisioning for listed banks are otherwise adequate. They are based on IFRS-equivalent accounting rules and regulatory requirements for classifying loans. CBRC does regular, extensive and in-depth reviews of asset quality and replication of the provisioning system. Major audit firms audit the majority of listed banks. The regulatory system has encouraged additional provisions and requires further buffers to be held as part of firm's equity.

\section{Traded market risk in the Chinese banking system is low in aggregate and for} major banks individually. This will likely increase as market liberalization occurs. The exchange rate liberalization announced recently could increase foreign exchange (FX) risk for banks and their customers. Risk management tools, information technology (IT) and data infrastructure to support them are generally commensurate with the level of risk, though there are areas for improvement. However, sophistication will likely need to increase considerably in the near future. The move to Basel II will assist. Interest Rate Risk in the Banking Book (IRRBB) is a more-prevalent risk for a wide number of banks. These will also likely rise as further liberalization occurs. Tools need to move rapidly beyond the static gap analysis based on contractual maturities of assets and liabilities that many banks are now employing. CBRC could also enhance its outlier analysis for this risk. This affects more than just the listed banks, and the improvement does not require adoption of models.

\section{Operational risk has been a focus of banks for a number of years. The two main} operational risks have related to possible internal control breakdowns and fraud, and IT risk. These have received considerable focus at banks and they and other observers reported that such incidents have trended down significantly in recent years. The challenge now is to put in place more comprehensive frameworks to deal with all elements of operational risk relevant to individual banks, which has started. More bank business units should be doing regular risk 
and control self assessment (RCSA) and developing, monitoring and refining key operational risk indicators. Again, a move to complex advanced measurement approaches (AMA) models for capital purposes is not required to make improvements.

\section{Methods of ongoing banking supervision (CPs 19-21)}

118. Supervisory approaches are increasingly risk focused. However, use of the CAMELS+ rating system and various other aspects of the supervisory methodology (including its newness in some respects) mean that supervisory assessments are not as forward looking as desirable. As well, heavy reliance on the few basic simple ratios, while appropriate, may discourage more judgment-based assessment of inherent risk and the quality of individual bank's risk management and governance. There is need to maintain the benefits of simple basic indictors while reinforcing banks complying with CBRC guidance which requires use of more sophisticated approaches than some banks are using. That would also encourage more of a risk culture in banks as well, rather than them relying excessively only on complying with regulatory requirements.

119. More attention may need to be placed on mid-size and smaller banks to ensure that they upgrade their risk management and governance performance. CBRC has all the necessary tools of on-site and off-site supervision. There is an extensive system to capture frequent and periodic information from banks. However, disclosure by banks or CBRC of important safety and soundness information, such as capital and liquidity position is less than in a lot of other markets. This should be examined and improved.

\section{Accounting and disclosure (CP 22)}

120. China has developed an accounting system that has substantially converged with the IFRS. A recent World Bank study also commended China's effort though certain areas of improvements were identified. Continued attention will need to be given to the development of the private accounting and audit profession in China to ensure that financial statements are professionally prepared and audited. The CBRC should be empowered to reject and rescind the appointment of an external auditor who is deemed to be unfit to perform a reliable and independent audit.

\section{Corrective and remedial powers of supervisors (CP 23)}

121. CBRC has the authority and demonstrated willingness to act to resolve problems. Dealing with problem banks has been on the basis of going concern solutions. Capability to close institutions may need to be enhanced going forward. 


\section{Consolidated and cross-border banking supervision (CPs 24-25)}

\section{Consolidated supervision of banks and their direct subsidiaries and branches on} the mainland or offshore is of high quality. However, existing laws may permit more complex structures where consolidated supervision may not be possible. On occasion, CBRC has used indirect and informal means to deal with the situation and bring about needed changes in structure. The mission's recommendations (CP 4) to amend laws to formally require $\mathrm{CBRC}$ approvals of ultimate beneficial ownership and indirect changes in control would also help address this issue. Reliance by one supervisor on the work of others in mixed corporate groups (bank/insurance/fund management/pilots) may not always work well in practice and has yet to be tested. In terms of home-host relationships, CBRC has a wide network of formal and informal arrangements and has used these effectively as both a home and host.

\section{Table 14. China: Summary Compliance with the Basel Core Principles}

\begin{tabular}{|c|c|}
\hline Core Principle & Comments \\
\hline $\begin{array}{l}\text { 1. Objectives, independence, powers, } \\
\text { transparency, and cooperation }\end{array}$ & \\
\hline 1.1 Responsibilities and objectives & $\begin{array}{l}\text { CBRC has clear safety and soundness goals in legislation, but the } \\
\text { authorities have recently also emphasized loan growth, particularly in } \\
\text { certain sectors to assist development and macroeconomic recovery. The } \\
\text { CBRC message of balancing this growth with prudence needs to be } \\
\text { continuously emphasized. The } 12^{\text {th }} \text { plan for the financial sector being } \\
\text { developed as part of the } 12^{\text {th }} \text { five year economic plan under the SC for } \\
\text { the NPC should reinforce the importance of safety and soundness. } \\
\text { CBRC leadership should continue to emphasize that banks follow sound } \\
\text { practices in implementing national economic policies. }\end{array}$ \\
\hline $\begin{array}{l}1.2 \text { Independence, accountability } \\
\text { and transparency }\end{array}$ & $\begin{array}{l}\text { Budgeting arrangements, external headcount approval requirements and } \\
\text { authority (though not used to date) for SC overrides of CBRC rules and } \\
\text { decisions compromise CBRC effectiveness and could affect operational } \\
\text { independence. CBRC needs to continuously upgrade its staff, including } \\
\text { developing more specialist expertise to be effective in the emerging } \\
\text { more complex, more innovative and more international environment. It } \\
\text { needs government support for a targeted strategy to achieve this goal } \\
\text { that will have to include more flexibility in budgeting and salaries and } \\
\text { incentives to attract and retain the people it needs to supervise } \\
\text { increasingly complex banks, and meet its other objectives. A more } \\
\text { forward-looking approach to resource planning and greater transparency } \\
\text { around performance measures is also desirable. }\end{array}$ \\
\hline 1.3 Legal framework & $\begin{array}{l}\text { The legal framework for banking supervision has been revised to } \\
\text { incorporate sound practices based on international standards. Some legal } \\
\text { provisions (mentioned elsewhere) need strengthening and some overlaps } \\
\text { clarified in the next round of amendments. }\end{array}$ \\
\hline
\end{tabular}




\begin{tabular}{|c|c|}
\hline Core Principle & Comments \\
\hline 1.4 Legal powers & $\begin{array}{l}\text { CBRC has been empowered to take a wide range of corrective and } \\
\text { remedial actions to deal with non-compliance and imprudent actions by } \\
\text { banks. }\end{array}$ \\
\hline 1.5 Legal protection & $\begin{array}{l}\text { CBRC staff is protected from the legal consequences of actions taken in } \\
\text { good faith. }\end{array}$ \\
\hline 1.6 Cooperation & $\begin{array}{l}\text { There exist a plethora of agreements and arrangements for sharing } \\
\text { information and coordination between the domestic agencies but the } \\
\text { Interagency Financial Coordination Meetings led by the SC are viewed } \\
\text { by many as being the most effective. }\end{array}$ \\
\hline 2. Permissible activities & $\begin{array}{l}\text { The permissible activities of banks are well defined and the authorities } \\
\text { lay particular emphasis on preventing unauthorized deposit taking. } \\
\text { While banks are prohibited from undertaking nonbank activities, some } \\
\text { pilots have been permitted to test the waters. Banks' transactions with } \\
\text { trust companies, which manage individual and institutional wealth have } \\
\text { increased significantly in recent times and are believed to reflect both a } \\
\text { search for yield and a sale of loans to meet regulatory ratios. }\end{array}$ \\
\hline 3. Licensing criteria & $\begin{array}{l}\text { The CBRC devotes significant resources to the licensing and approvals } \\
\text { regime which is comprehensive and covers prior authorization for all } \\
\text { activities, services and products. }\end{array}$ \\
\hline 4. Transfer of significant ownership & $\begin{array}{l}\text { CBRC is inhibited in its formal legal ability to identify the ultimate } \\
\text { beneficial owner or controlling shareholder while approving transfers of } \\
\text { significant ownership in banks and employs indirect and/or informal } \\
\text { approaches towards this end. }\end{array}$ \\
\hline 5. Major acquisitions & $\begin{array}{l}\text { More clarity to be provided on the criteria by which to judge major } \\
\text { acquisitions of domestic banks by other domestic banks. }\end{array}$ \\
\hline 6. Capital adequacy & $\begin{array}{l}\text { CBRC has adopted a generally conservative approach to implementing } \\
\text { Basel I with few exceptions. There are expectations of banks holding } \\
\text { capital above the Basel minimum with three quarters of capital required } \\
\text { composed of core capital. CBRC's recent adoption of their expectation } \\
\text { of a capital buffer as a counter-cyclical measure could be further } \\
\text { articulated to be effective. There is a lack of a permanent well- } \\
\text { understood cushion above minimum required capital. Implementation of } \\
\text { Basel II is pushing major banks to further improve risk management but } \\
\text { resources within CBRC for effective implementation on the current } \\
\text { timetable may be strained. }\end{array}$ \\
\hline 7. Risk management process & $\begin{array}{l}\text { While much of banking in China is deposit taking and lending, major } \\
\text { Chinese banks are some of the largest in the world, and the Chinese } \\
\text { lending market is complex by virtue of its scope and diversity, and } \\
\text { banks are getting into new areas of lending and other activities. So risk } \\
\text { management needs to be commensurate with these realties. CBRC has } \\
\text { put in place high-quality internationally-compliant guidance (some } \\
\text { relatively recently). Banks have not yet fully complied, the gaps are } \\
\text { material for some banks, and practice will likely take time to be in place. }\end{array}$ \\
\hline
\end{tabular}




\begin{tabular}{|c|c|}
\hline Core Principle & Comments \\
\hline & $\begin{array}{l}\text { Major banks and mid-size banks have processes for management of } \\
\text { credit/market/operational risks. However, true enterprise-wide risk } \\
\text { approaches that integrate strategy setting, monitoring, management and } \\
\text { stress testing in ways that consider interactions among risks are at an } \\
\text { early stage in some banks, including some major ones. Guidance on } \\
\text { some risks is recent and so could not be expected to be complied with as } \\
\text { yet (e.g., comprehensive risk management, liquidity risk, reputation } \\
\text { risk). A period of settling in is required for existing and newly- } \\
\text { developed processes to be fully effective and be assessed by the } \\
\text { supervisor. } \\
\text { Processes for banks to relate the capital they hold to their risks are at an } \\
\text { early stage in banks and the supervisor. For major banks this will be } \\
\text { enhanced over time by the move to Basel II. Some further more-detailed } \\
\text { guidance for smaller banks on relating capital to risk may be needed. }\end{array}$ \\
\hline 8. Credit risk & $\begin{array}{l}\text { This is the key risk in the Chinese banking system and will remain so for } \\
\text { some time. Recent success in cleaning up banks portfolios is impressive. } \\
\text { But credit risk is likely rising. CBRC guidance is appropriate. Credit risk } \\
\text { management in many banks has improved greatly recently, and } \\
\text { assessors saw many examples of excellent practices. However assessors } \\
\text { saw clear evidence that the enhancements in governance related to credit } \\
\text { risk and credit risk management is not fully embedded across all banks } \\
\text { (and have not been tested under stress). Many banks appear to be relying } \\
\text { more on the regulatory NPL ratios in setting credit strategies. CBRC has } \\
\text { had to take a variety of action to push banks to improve underwriting } \\
\text { and credit-risk management processes that would not have been } \\
\text { necessary if bank risk management practices were more fully reliable. }\end{array}$ \\
\hline $\begin{array}{l}\text { 9. Problem assets, provisions, and } \\
\text { reserves }\end{array}$ & $\begin{array}{l}\text { Assessors spent considerable time reviewing this principle. Most banks } \\
\text { follow relevant accounting principles in determining loan loss allowance } \\
\text { and comply with regulatory minima set by CBRC. A lot of efforts are } \\
\text { made by CBRC and auditors of major banks to ensure that provisioning } \\
\text { meets accounting and regulatory requirements. Smaller banks appear to } \\
\text { face challenges in following accounting principles relating to } \\
\text { determining individual and collective impairment. Banks' ability to } \\
\text { write off loans in a timely way has been negatively impacted by the } \\
\text { strict -write-off criteria laid out by MoF. }\end{array}$ \\
\hline 10. Large exposure limits & $\begin{array}{l}\text { CBRC lays great emphasis on identifying large exposures through a } \\
\text { dedicated off-site system. However, it should also consider developing a } \\
\text { more comprehensive framework for assessing risk across } \\
\text { connected/related-parties. }\end{array}$ \\
\hline 11. Exposure to related parties & $\begin{array}{l}\text { While a robust regime is prescribed for identifying related parties and } \\
\text { requiring that transactions with them be undertaken at arm's length and } \\
\text { be subject to limits, it does not take into account common ownership by } \\
\text { local governments, which may be a risk factor for some banks owned by } \\
\text { local governments. }\end{array}$ \\
\hline
\end{tabular}




\begin{tabular}{|c|c|}
\hline Core Principle & Comments \\
\hline 12. Country and transfer risks & $\begin{array}{l}\text { Country and transfer risks are gaining in materiality for Chinese banks. } \\
\text { While the major banks with the bulk of the exposure have systems in } \\
\text { place, this is still work in progress for the others. CBRC has recently } \\
\text { consolidated its supervisory expectations in this regard and is } \\
\text { monitoring progress in implementation. }\end{array}$ \\
\hline 13. Market risks & $\begin{array}{l}\text { The extent and complexity of market risk is low given market structure } \\
\text { and absence of approval for complex products, and banks strategies } \\
\text { being more client-driven than proprietary. While existing risk } \\
\text { management approaches are reasonable for the current environment, } \\
\text { there are weaknesses in execution and a material upgrade will be needed } \\
\text { if any further interest rate or exchange rate liberalization occurs or if } \\
\text { banks adopt more aggressive strategies. }\end{array}$ \\
\hline 14. Liquidity risk & $\begin{array}{l}\text { Use of simple regulatory rules such as maximum loan/deposit ratio and } \\
\text { minimum current assets ratio, as well as reserve requirements, mean } \\
\text { banks are highly liquid. Banks should be encouraged to adopt more } \\
\text { sophisticated liquidity risk management methods to prepare for further } \\
\text { market liberalization. }\end{array}$ \\
\hline 15. Operational risk & $\begin{array}{l}\text { Banks and the supervisor have considerable history of detailed high- } \\
\text { quality internal control processes (focused on reducing fraud) and } \\
\text { attention to IT risks. The current challenge is to move beyond that to a } \\
\text { more-complete measurement and management of operational risk. } \\
\text { Progress is occurring but this varies across larger banks. Guidance that } \\
\text { covers all elements of the CP is recent and upgrading of specialist skills } \\
\text { in CBRC will be required. Practice of banks doing RCSA across } \\
\text { businesses or developing key risk indicators (KRI) for various business } \\
\text { lines needs further development. }\end{array}$ \\
\hline $\begin{array}{l}\text { 16. Interest rate risk in the banking } \\
\text { book }\end{array}$ & $\begin{array}{l}\text { This is a risk that is meaningful for a wide variety of banks of all sizes. } \\
\text { The need for active management will likely grow as and when further } \\
\text { interest rate liberalization occurs. Currently many banks are using static } \\
\text { gap analysis based on contractual maturities to measure and manage this } \\
\text { risk. It is desirable to move to more dynamic analysis based on projected } \\
\text { cash flows, non-parallel shifts in interest rates and incorporating } \\
\text { assumptions about how the behavior of various categories of assets and } \\
\text { liabilities might be affected in these scenarios. There is room for CBRC } \\
\text { to enhance its analysis of possible outliers. }\end{array}$ \\
\hline 17. Internal control and audit & $\begin{array}{l}\text { Internal control awareness has been heightened and the CBRC has } \\
\text { strong supervisory focus in this area. Publicly listed banks will face the } \\
\text { challenge of implementing "C-SOX" which requires external auditors to } \\
\text { opine on the adequacy of their self assessments of internal controls. }\end{array}$ \\
\hline 18. Abuse of financial services & $\begin{array}{l}\text { The supervisory responsibilities for addressing the abuse of financial } \\
\text { services in (and by) banks are divided between the PBC and the CBRC. } \\
\text { There are opportunities for improving cooperation and information } \\
\text { sharing between the two as they carry out this shared responsibility. }\end{array}$ \\
\hline
\end{tabular}




\begin{tabular}{|c|c|}
\hline Core Principle & Comments \\
\hline & $\begin{array}{l}\text { CBRC is making material strides in dealing with fraudulent practices in } \\
\text { banks but some work remains to be done. A few Anti-Money } \\
\text { Laundering (AML) related recommendations relevant for banks as } \\
\text { identified in the } 2006 \text { FATF assessment are to be addressed. }\end{array}$ \\
\hline 19. Supervisory approach & $\begin{array}{l}\text { While the supervisory approaches are increasingly risk-focused and } \\
\text { incorporate good practices, supervisors should consider focusing on } \\
\text { incorporating more examiner judgment in ratings and lessen reliance on } \\
\text { quantitative formulaic approaches. }\end{array}$ \\
\hline 20. Supervisory techniques & $\begin{array}{l}\text { To further the risk-based approaches in place, CBRC should reconsider } \\
\text { its focus on examination of branches which are largely compliance } \\
\text { focused. Resources could then be allocated to other higher priority } \\
\text { supervisory activities. }\end{array}$ \\
\hline 21. Supervisory reporting & $\begin{array}{l}\text { There is an extensive system to capture frequent and periodic } \\
\text { information from banks and CBRC should consider making banks' } \\
\text { quarterly financial information available to the public to foster greater } \\
\text { transparency in the banking industry. }\end{array}$ \\
\hline 22. Accounting and disclosure & $\begin{array}{l}\text { The CBRC does not have the authority to reject or rescind the } \\
\text { appointment of an external auditor who is deemed unfit to perform a } \\
\text { reliable and independent audit. The October } 2009 \text { World Bank Report on } \\
\text { the ROSC-Accounting and Auditing identifies weaknesses in the audit } \\
\text { quality of the smaller and mid-sized accounting firms and the oversight } \\
\text { of the accounting profession. The lack of published financial data on } \\
\text { aggregate and individual bank data reduces the transparency of the } \\
\text { banking system. }\end{array}$ \\
\hline $\begin{array}{l}\text { 23. Corrective and remedial powers of } \\
\text { supervisors }\end{array}$ & $\begin{array}{l}\text { CBRC has the ability to act to take corrective action if prudential rules } \\
\text { are not observed and data on enforcement actions suggest that it also has } \\
\text { the willingness to act in this regard. Bank closing experience has been } \\
\text { very limited though there have been large-scale mergers as part of } \\
\text { banking system consolidation in which CBRC has been involved. }\end{array}$ \\
\hline 24. Consolidated supervision & $\begin{array}{l}\text { Consolidated regulation and supervision of groups composed of banks } \\
\text { and their mainland or offshore subsidiaries and branches is of high } \\
\text { quality. Laws and rules permit more complex structures where CBRC } \\
\text { would be challenged to meet the key elements of the principle. With } \\
\text { cross ownership by banks of fund management companies and insurers } \\
\text { (pilots exist) reliance on firewalls and institutional regulation by each } \\
\text { regulator of their part of the group may not be sufficient. }\end{array}$ \\
\hline 25. Home-host relationships & $\begin{array}{l}\text { CBRC has laid emphasis on developing and maintaining a wide network } \\
\text { of formal and informal arrangements with overseas supervisory } \\
\text { authorities and has used these effectively as both a home and a host. It } \\
\text { has also launched a supervisory college for one large international bank } \\
\text { and will shortly launch a second one. }\end{array}$ \\
\hline
\end{tabular}




\section{Table 15. China: Recommended Action Plan to Improve Compliance with the Basel Core Principles}

\begin{tabular}{|c|c|}
\hline Reference Principle & Recommended Action \\
\hline CP 1.1 Responsibilities and Objectives & $\begin{array}{l}\text { Ensure upcoming revised } 12^{\text {th }} \text { five year plan developed by the SC for the } \\
\text { financial sector emphasizes importance of safety and soundness including } \\
\text { early intervention by the regulator to get potential problems resolved and } \\
\text { the contribution safe and sound banks make to achieving economic and } \\
\text { social goals. Make improving banks' risk management as a way of } \\
\text { supporting economic and social goals a priority over the next five years- } \\
\text { not just in leading banks but in all banks. Consider amending CBRC } \\
\text { objectives to emphasize early intervention. Reduce focus on NPLs and } \\
\text { increase focus on more forward-looking monitoring and measurement of } \\
\text { risk. CBRC leadership to continue to emphasize the importance of } \\
\text { prudential goals in implementation of national economic policies. }\end{array}$ \\
\hline $\begin{array}{l}\text { CP } 1.2 \text { Independence, Accountability } \\
\text { and Transparency }\end{array}$ & $\begin{array}{l}\text { Give CBRC authority for staffing and budgeting within broadly-set targets. } \\
\text { Consider moving to model where industry fees directly fund CBRC to } \\
\text { enhance independence. Develop a SC supported plan to upgrade CBRC } \\
\text { staff expertise including more budget flexibility and allowing CBRC more } \\
\text { flexibility in remuneration to better attract and retain specialist resources. } \\
\text { Address potential independence issues. }\end{array}$ \\
\hline CP 4 Transfer of Significant Ownership & $\begin{array}{l}\text { The law should clearly require evaluations of ultimate beneficial owners } \\
\text { and shareholders exercising indirect control in all cases of acquisition and } \\
\text { transfers of significant ownership in banks. }\end{array}$ \\
\hline CP 6 Capital Adequacy & $\begin{array}{l}\text { Reconsider the few areas where capital rules are less conservative than } \\
\text { Basel I. Consider ways to draw out implementation of Basel II to ensure } \\
\text { success, such as a longer parallel run period. Secure more specialist } \\
\text { resources on an ongoing basis to effectively supervise Basel II banks. } \\
\text { Enhance disclosure of capital position of banks. }\end{array}$ \\
\hline CP 7 Comprehensive Risk Management & $\begin{array}{l}\text { Persevere in current direction to improve bank compliance with CBRC } \\
\text { guidance. Ensure adequate focus on risk management capabilities of the } \\
\text { banks, not just the Basel II banks. Encourage banks to have more risk- } \\
\text { related measures in their annual board-approved strategy setting. Perform } \\
\text { cross-bank targeted review of risk management practices with focus on } \\
\text { enterprise-wide approach, benchmark banks and provide feedback on areas } \\
\text { for improvement. Encourage use of more enterprise wide scenario stresses } \\
\text { such as how a slowdown would affect all risk areas. Encourage more } \\
\text { relating of capital banks hold to their risks. Consider targeted review of } \\
\text { this across major banks, benchmark, and provide feedback. Consider more } \\
\text { detailed guidance on relating capital to risk for non-Basel II banks. }\end{array}$ \\
\hline CP 8 Credit Risk & $\begin{array}{l}\text { Further develop more forward-looking assessment of credit risk in CBRC } \\
\text { risk rating system. Encourage banks to use more of their own risk metrics } \\
\text { in setting their annual credit risk strategies. Make sure all major banks } \\
\text { have implemented CBRC credit risk guidance. }\end{array}$ \\
\hline CP 9 Problem Assets & $\begin{array}{l}\text { Establish a less burdensome mechanism to facilitate the loan write-off } \\
\text { process. }\end{array}$ \\
\hline
\end{tabular}




\begin{tabular}{|c|c|}
\hline Reference Principle & Recommended Action \\
\hline $\begin{array}{l}\text { CP 10, } 11 \text { Large Exposures and Related } \\
\text { Party Lending }\end{array}$ & $\begin{array}{l}\text { Bring common ownership of enterprises by local governments into the } \\
\text { definition and discipline of large exposures and related party transactions. }\end{array}$ \\
\hline CP 12 Country and Transfer Risk & $\begin{array}{l}\text { Ensure implementation of country and transfer risk management guidance } \\
\text { (issued in June 2010) in all major banks. Have banks submit an action plan } \\
\text { to deal with deficiencies by year-end 2010. Perform a supervisory review } \\
\text { of policies and practice for these banks within the next } 18 \text { months. }\end{array}$ \\
\hline CP 13 Market Risk & $\begin{array}{l}\text { Develop and implement an effective strategy to increase specialist } \\
\text { resources in this area. Repeat the } 2006 \text { cross-system review of market risk } \\
\text { management at regular intervals as a means of assessing progress, } \\
\text { benchmarking and pushing for continuous improvement. Review } \\
\text { appropriateness of threshold for exemption from market risk capital } \\
\text { determination. }\end{array}$ \\
\hline CP 14 Liquidity Risk & $\begin{array}{l}\text { Put additional supervisory focus on this area as a means of reinforcing } \\
\text { implementation of the guidance issued in } 2009 \text {. Signal to banks at senior } \\
\text { levels the desire for more sophisticated liquidity risk management. Put } \\
\text { high priority on performing an assessment of all major banks against the } \\
\text { new guidance. }\end{array}$ \\
\hline CP 15 Operational Risk & $\begin{array}{l}\text { Ensure all major banks have a plan to develop at least RCSA and KRI } \\
\text { across their businesses. Enhance expertise of CBRC resources to permit } \\
\text { cross-system review of major banks progress against } 2007 \text { guidance. } \\
\text { Priority is less than for liquidity and IRRBB. Guard against pressure for } \\
\text { premature moves to AMA. }\end{array}$ \\
\hline CP 18 Abuse of Financial Services & $\begin{array}{l}\text { Improve coordination and information sharing between CBRC and PBC } \\
\text { through more regular and frequent information including those arising } \\
\text { from AML inspection findings; and large and doubtful transaction reports. } \\
\text { Develop an information sharing protocol between CBRC and PBC. } \\
\text { Continue progress on dealing with fraudulent transactions in and by banks. } \\
\text { Make it legally binding on banks to identify beneficial customers. }\end{array}$ \\
\hline CP 22 Accounting and Disclosure & $\begin{array}{l}\text { Develop an auditor independence requirement to enhance the credibility of } \\
\text { the auditing profession. } \\
\text { Prioritize implementation of policy recommendations identified in the } \\
\text { October } 2009 \text { World Bank ROSC Report on Accounting and Auditing } \\
\text { focusing on improving the audit quality of the smaller to mid-sized } \\
\text { accounting firms and stronger oversight of the accounting profession. } \\
\text { Empower CBRC to reject or rescind the appointment of an external } \\
\text { auditor who is deemed unfit to perform a reliable and independent audit by } \\
\text { them. Enhance the transparency of the banking system by publishing } \\
\text { aggregate banking data, key financial ratios, and peer group averages } \\
\text { quarterly. The frequency of audit oversight inspections should be } \\
\text { increased. }\end{array}$ \\
\hline
\end{tabular}




\begin{tabular}{|l|l|}
\hline \multicolumn{1}{|c|}{ Reference Principle } & \multicolumn{1}{c|}{ Recommended Action } \\
\hline CP 24 Consolidated Supervision & $\begin{array}{l}\text { Amend legislation to give CBRC authority to force banks in all cases to be } \\
\text { held in corporate structures that permit consolidated supervision. Use new } \\
\text { authority regarding beneficial ownership and indirect control (CP 4) to } \\
\text { ensure corporate structures permit consolidated supervision. Give CBRC } \\
\text { authority to examine fund management and insurance affiliates of banks if } \\
\text { concerns regarding risk and risk management capabilities exist. }\end{array}$ \\
\hline
\end{tabular}

\section{F. Authorities' Response}

123. The Chinese authorities welcome and support the BCP assessment as an opportunity for reflection and improvement for banking regulation and supervision according to international standards. The assessment team has undertaken excellent work, demonstrating high quality professionalism, dedication and the ability to cut through complex issues in a constrained timeframe. The authorities appreciate the opportunity to provide the following comments on the assessment.

124. The CBRC, with strong support from the Chinese government, has actively pursued its statutory mandate for safety and soundness of the banking sector through promulgating a prudential framework benchmarked to international standards and continuously improving supervisory effectiveness. This effort is facilitated by substantial enhancement in corporate governance and risk management in the Chinese banking industry through three decades of reform and opening up. These achievements and progress have been largely recognized in the assessment report. The assessment demonstrates that the banking supervision in China is broadly in compliance with the BCP.

125. There are a number of issues in the assessment for which the authorities would like to provide further clarification. The assessment identifies the potential ability for the SC to override CBRC rules as a potential threat to CBRC's operational independence. The CBRC does not see this as an independence concern that would compromise its effectiveness. According to the Law on Banking Regulation and Supervision, the CBRC shall, in accordance with applicable laws and administrative regulations, formulate and promulgate supervisory rules and guidelines for banking institutions. And according to the Legislation Law, only under the circumstances of violating laws and regulations, or existence of inconsistencies between rules issued by different ministries or commissions, the SC may alter or annul "inappropriate" rules issued by the ministries or commissions. Therefore, the CBRC can perform its rule-making authority independently unless its rules and guidelines contravene relevant laws or administrative regulations. Such an arrangement serves as a check and balance on the CBRC and other government agencies to exercise authority in accordance with law. This also helps maintaining the integrity and consistency of the legal 
framework in China. In practice, the SC has never altered or annulled the rules and guidelines issued by the CBRC.

126. The assessment also indicates that the CBRC's current budgeting and headcount arrangements could lead to potential independence issues and hamper supervisory effectiveness. Since its establishment, the CBRC has received unrelenting support from the $\mathrm{SC}$ and relevant ministries in undertaking banking regulation and supervision. The CBRC has upgraded the efficiency and quality of its staff through continuous recruiting, training and development efforts, while the efficiency of supervision has also been enhanced through effective application of IT. However, the CBRC acknowledges that, like many banking supervisory agencies around the world, it faces challenges in attracting, developing and retaining supervisory talent in an increasingly competitive and complex industry environment. By working closely with relevant government agencies, the CBRC aims to further increase supervisory resources where appropriate, upgrade staff skills and retain highquality front-line supervisors, in order to fulfill its mandate for safety and soundness in a fast changing industry environment.

127. The CPs revised in 2006 place a greater emphasis on risk management, and the methodology requires assessors to consider the practices of banks as well as supervisory agencies. The $\mathrm{CBRC}$, since its establishment, has made great efforts to improve its risk-based supervision capacity, while requiring banks to enhance their corporate governance and risk management capabilities. To this date, the main business of Chinese banks is still traditional deposit-taking and commercial and retail lending. It is only in recent years that a few banks have been allowed to enter into non-bank financial businesses on a trial basis and these operations remain very small. As a result, China's banking sector is much simpler than those of developed markets, where the risk environment is much more challenging due to greater complexity and interconnectedness. The assessment acknowledges that the CBRC has played a major role in the significant and impressive progress that banks have made in improving their risk management, while identifying a number of areas for further improvement. The authorities' view differs from the assessment in the degree to which banks' risk management is commensurate with the current risk environment they operate in. However, the authorities concur that continued improvements in banks' risk management are needed, as financial reform deepens and liberalization creates greater interconnectedness and complexities in the Chinese financial system. For example, looking ahead, comprehensive enterprise-wide risk management that takes account of interactions among risks and effectively relates capital to risks will need to be further strengthened at the Chinese banks. Meanwhile, the CBRC will also continue to enhance its capability in evaluating banks' risk profiles and risk management processes together with the increase in size and complexity of the Chinese banking sector.

128. The assessment has proven to be valuable and rewarding in generating insights and suggestions that will contribute towards the improvement of banking supervision in China. The CBRC appreciates the recommendations made in the assessment, and will take actions 
on those that are considered appropriate and applicable. Some of them are already being implemented and others taken into account in the CBRC's medium- and long-term plans to improve supervisory effectiveness. The CBRC will also continue to push forward the reform and opening-up of the Chinese banking sector, which has proven a key driver in enhancing the safety and soundness of Chinese banks. In the meantime, the CBRC will continue to actively engage in the activities of the FSB and the BCBS to develop and reform international banking supervisory standards, so as to contribute towards the enhancement of the resilience of the global banking system. 


\section{ANNEX II: ObServance OF FinanCial Sector STANDARdS ANd CODES-IAIS Insurance Core Principles: A Summary}

\section{A. Introduction}

129. Insurance companies in China are closely supervised and generally subjected to appropriate regulation. The $\mathrm{CIRC}$, employs a rules based framework and has achieved a high level of regulatory compliance from supervised companies. Generally, a high level of observance with the core principles can be seen on those core principles where a rules based approach and control can be exercised. In contrast insufficient regulation exists on market exit and portfolio transfers. Supervision should be strengthened on the adequacy of reserve levels, the insurer's observance of solvency requirements and the strictness with which CIRC ensures compliance with capital requirements. A shift from rules based to principles based supervision is likely to become necessary if resources are to meet growing demands. However in the immediate future rules based approach seems most appropriate.

\section{This assessment of compliance with International Association of Insurance} Supervisors (IAIS) Insurance Core Principles (ICP) was carried out as part of the 2010 FSAP. The assessment is based on the 2003 version of the IAIS Insurance Core Principles and Methodology. It took into account relevant IAIS standards and guidance in addition to the ICPs.

\section{The CIRC conducts its duties through its headquarters in Beijing and}

35 regional branches, the insurance bureaus. Insurance regulations issued by the CIRC are guided by high level regulations issued by the SC (including on compulsory motor insurance) and the basic law issued by the People's Congress. In addition to formal regulations, CIRC has issued a range of directives, guidance notes etc under its mandate to develop the SC's commercial and social policy objectives for the insurance market.

\section{This assessment is based upon information made available to the assessor in} preparation for and during the June 2010 FSAP mission. CIRC contributed a selfassessment and further information in response to requests before and during the mission. Requested documentation, including relevant laws and a number of key regulations were supplied in English. However many of the 42 key CIRC regulations and supporting directives and explanations were only available in Chinese. The assessment has been informed by discussions with regulators and market participants. The assessors met with staff from the CIRC Headquarters (HQ), two large regional insurance bureaus, insurance companies and intermediaries, and with the accounting and actuarial professions. The assessors are grateful for the full cooperation extended by all. 


\section{B. Institutional and Market Structure-Overview}

133. The Chinese insurance market is the six largest in the world. At the end of 2009 there were 59 life insurers, 52 non-life (Property and Casualty $(\mathrm{P} \& \mathrm{C})$ or property) insurers, and nine reinsurers, including one specialist credit insurer, and four specialist agricultural insurers (one of which is a mutual). The four specialist heath insurers are classified as part of the personal (life, etc.) insurance sector. Non-life insurers may now also write short term medical coverage. Eight insurance groups have been formed under holding company structures and 10 insurers have established asset management companies. Life insurance premium income in 2009 was US\$109.2 billion, a penetration of 2.3 percent of GDP and a metric typical of a relatively advanced economy. In 2009 non life insurance generated US\$ 53.9 billion of premium, a penetration of 1.1 percent of GDP. The P\&C sector is dominated by motor insurance (which accounted for 70 percent of gross written premium) a metric more characteristic of an emerging market. This unusual pattern is likely to reflect both cultural and historical roots.

134. China's life insurance market is highly concentrated. The top 10 insurance companies account for nearly 90 percent of gross premium. With the exception of American International Assurance Company (AIA), life insurance business is not open to foreign funded companies except through joint ventures where the foreign shareholder may have up to 50 percent of the equity. ${ }^{9}$ The non-life business is also highly concentrated and continues to be dominated by the leading P\&C Insurance Group the People's Insurance Company of China (PICC).

\section{The life insurance business mix has changed significantly in the last half of this}

decade. The traditional guaranteed return business has dropped from 42 percent to 23 percent of life policies and being replaced by Universal Life and Investment linked business. Participating business ${ }^{10}$ throughout the decade has held approximately 55 percent of the market as it has provided a reasonably consistent and stable profit margin for the insurers and offers the possibility of an enhanced return to the policyholders.

136. The non life business mix has remained largely static. Motor and commercial property accounts for 80 percent and liability, Marine Aviation and Transit (MAT) and accident jointly account for another 11 percent. The only clear upward trend in share of premium has been in the agricultural and medical insurance lines. Household insurance accounts for only 1 percent of non-life premium and China, unlike other countries, is not

\footnotetext{
${ }^{9}$ Two foreign shareholders other than American International Group (AIG) have 51 percent shareholdings reflecting special circumstances.

${ }^{10}$ Participating business has a low guaranteed return and offers the opportunity for additional participation in emerging profits.
} 
seeing a boost in insurance sales from the development of the mortgage markets. It appears in part this may be due to banks not being prepared to monitor and enforce policy continuance.

\section{Main Findings}

137. The preconditions for effective supervision are generally met. Where principles are not full observed, generally one of two reasons applies:

- $\quad$ CIRC or other empowered official agencies have intentionally decided that the full implementation of the respective core principle would not fully take into account the current development phase of the Chinese insurance market or would be in conflict with constitutional arrangements. This observation may be applicable to principles on: supervisory authority, supervisory objectives, investments, derivatives and AML.

- $\quad$ CIRC has - in contrast to its overall comprehensive regulations - insufficient rules for some important areas of supervision. China takes a fairly pragmatic approach to regulation and will often wait for the actual emergence of business cases demanding new rules before acting. It is responsive rather than proactive and has thus missed important areas. This observation is applicable to principles on: change in control and portfolio transfer, exiting the market and insurance activity.

\section{There also areas, where CIRC has strong and explicit regulation in place but its} application or implementation is assessed as being too loose and also bearing substantial reputational risks for CIRC. This observation would be applicable to principles on: liabilities and solvency regime.

- $\quad$ CIRC has implemented a comprehensive supervisory framework and strong emphasis has been given to the implementation of suitable corporate governance rules and sufficient risk management systems for all insurance companies. The conditions for effective insurance supervision are largely met with some impediments stemming from the continuing battle of Chinese officials against corruption and bribery.

- $\quad$ The supervisory system is strong and well organized but CIRC has a compelling need for additional resources in its core supervisory departments. CIRC is responsible for a wide range of tasks in a very large and diversified market. It also has to be prepared for the continuing rapid growth of the scale and scope of China's many and diverse insurance markets. Today, its qualified staffing in some departments may not be adequate to permit it to carry out its responsibilities in a growing and changing market.

- $\quad$ The principles regarding the supervised entities are largely observed. Further regulation should be issued to facilitate portfolio transfers and to disconnect licensing arrangements from the registration of the legal entity. 
- $\quad$ CIRC's ongoing supervision of insurance companies and the supervision of markets and consumers are tight and display a strong level of control. Most principles in these sections are fully observed. In fact, some of the supervisory reporting requirements seem almost too comprehensive and are reported too frequently. Disclosure and consumer protection are adequate and have recently been improved.

- The application of prudential requirements needs to be strengthened substantially, especially the liabilities and the solvency regimes. There are also some deficiencies in the regulation regarding quantitative investment requirements, but the authority has signaled that further regulation will be issued shortly. CIRC should also review its current arrangement with PBC on fighting Money-Laundering. The shared responsibilities are not reflected in the activities carried out solely by PBC. The lack of adequate reporting back to CIRC is not acceptable and bears a reputational risk for CIRC. Processes and responsibilities should be reviewed and restructured to address this weakness.

\section{Table 16. China: Summary of Observance of the Insurance Core Principles}

\begin{tabular}{|l|l|}
\hline \multicolumn{1}{|c|}{ Insurance Core Principle } & \multicolumn{1}{|c|}{ Comments } \\
\hline $\begin{array}{l}\text { ICP 1 - Conditions for effective } \\
\text { insurance supervision }\end{array}$ & $\begin{array}{l}\text { The preconditions for effective supervision are largely met. Stronger } \\
\text { enforcement is needed to eliminate a general perception of the acceptance } \\
\text { of corruption and to minimize unethical behavior in the financial sector. } \\
\text { CIRC bureaus have recently been engaged in an active campaign to } \\
\text { reduce fraudulent behavior and to enforce ethical behavior of insurance } \\
\text { company management and staff. } \\
\text { The influence of the Chinese authorities over business development and } \\
\text { companies' strategies is potentially hampering the desired growth of the } \\
\text { market. China has to resolve the contradiction between a controlled } \\
\text { market including tight control over the entry and expansion of foreign } \\
\text { funded companies and the need to develop the life insurance market to } \\
\text { provide sufficient coverage and innovations to facilitate the overall } \\
\text { growth of the Chinese markets. }\end{array}$ \\
\hline ICP 2 - Supervisory objectives & $\begin{array}{l}\text { CIRC's supervisory objectives are defined in broad terms. } \\
\text { Financial stability, consumer protection and fair competition could be } \\
\text { translated into operational goals and form the basis for a mission } \\
\text { statement of CIRC. That statement could also help new staff to engage } \\
\text { more quickly with the authority's tasks. } \\
\text { The CIRC's second objective and related responsibilities for the } \\
\text { development of the domestic market (as implemented) are rather unique } \\
\text { for a supervisor. It was made clear to the assessor that both sets of } \\
\text { objectives are essential to the controlled and sound growth of the sector } \\
\text { and the need to supply insurance coverage to consumers and domestic } \\
\text { industries. Generally supervisors support the development of the sector } \\
\text { through ensuring a level playing field and adequate and prompt } \\
\text { supervision. As such, the more hands on developmental objectives and }\end{array}$ \\
\hline
\end{tabular}




\begin{tabular}{|c|c|}
\hline & $\begin{array}{l}\text { responsibilities of CIRC are not in line with the ICP. } \\
\text { Moreover, the range of commercial and social objectives almost } \\
\text { inevitably will lead to conflicts with the supervisory objectives. Possible } \\
\text { scenarios include decisions on adequacy of pricing, product design and } \\
\text { consumer protection and licensing in the context of regional and social } \\
\text { development. The regulatory and commercial objectives each require very } \\
\text { distinct mindsets and skills. It is recommended the two mandates be } \\
\text { separated and a suitable agency be identified to take ownership of the } \\
\text { developmental, commercial and social objectives. This would help to } \\
\text { ensure the supervisor has a clear objective and is able to undertake its role } \\
\text { without conflict. This would help the government and the industry to } \\
\text { understand better the risks to safety and soundness of actions taken. }\end{array}$ \\
\hline ICP 3 - Supervisory authority & $\begin{array}{l}\text { CIRC is not entirely independent and free from political process. It } \\
\text { became apparent, that the Chinese regulatory framework is based on strict } \\
\text { control, cascading down from the state council to CIRC HQ to the } \\
\text { insurance bureaus. In addition, the staffing levels of CIRC are not } \\
\text { adequate. In particular, the areas of off-site monitoring, inspection, } \\
\text { international cooperation, accounting and auditing and the staffing levels } \\
\text { of key units in the insurance bureaus should be substantially strengthened } \\
\text { through increased suitable staffing. } \\
\text { As in ICP 2, it is recommended the commercial and social development } \\
\text { objectives be disconnected from CIRC and consideration be given to } \\
\text { establishing a development agency for the financial sector as a whole. As } \\
\text { such, that agency could ensure a closer alignment of development in the } \\
\text { banking, securities and insurance areas while also looking to the specific } \\
\text { needs of each sector. }\end{array}$ \\
\hline ICP 4 - Supervisory process & $\begin{array}{l}\text { At this time in the development of the sector the rules based approach for } \\
\text { supervision undertaken by CIRC is appropriate and it is not recommended } \\
\text { that CIRC should shift to a principle based system. In fact, interviews with } \\
\text { staff and industry, including auditors and actuaries, have confirmed that } \\
\text { the prescriptive system currently corresponds to the business culture in } \\
\text { China. This should be reexamined going forward to determine the } \\
\text { feasibility and appropriateness of the rules based approach as the industry } \\
\text { continues to change. In addition, in the future it will be necessary to } \\
\text { consider the potential impact on the CIRC which under the rules based } \\
\text { system requires staff sufficient to undertake the labor intensive processes. } \\
\text { Albeit that staff for CIRC will have to increase under both a rules and } \\
\text { principles based system, staffing levels will need to be increased } \\
\text { substantially under a rules based system in order to adequately manage the } \\
\text { expected enormous size of the market and the diversity of the provinces } \\
\text { and market players. }\end{array}$ \\
\hline $\begin{array}{l}\text { ICP } 5 \text { - Supervisory } \\
\text { cooperation and information } \\
\text { sharing }\end{array}$ & $\begin{array}{l}\text { The information sharing with authorities exists on an as-needs basis. It is } \\
\text { recommended to establish information sharing in a pro-active manner and } \\
\text { to provide those authorities supervising insurance groups with related } \\
\text { business in China with information on the Chinese market on a regular } \\
\text { basis. Reciprocally, CIRC should ask for respective information. }\end{array}$ \\
\hline
\end{tabular}




\begin{tabular}{|c|c|}
\hline ICP 6 - Licensing & $\begin{array}{l}\text { The licensing process should not be restricted to control the market entry } \\
\text { of insurers but must also facilitate changes of insurers' strategy and ability } \\
\text { to underwrite business. The separation of the formation of a company and } \\
\text { insurance licensing should be made clearer. CIRC must be able to ensure } \\
\text { that a company may be prohibited from writing new policies but still is } \\
\text { liable and able to administer its current liabilities and contracts. }\end{array}$ \\
\hline ICP 7 - Suitability of persons & $\begin{array}{l}\text { An insurance company has to apply for approval before changing its } \\
\text { external auditor. In doing so, only the firm but not the responsible partners } \\
\text { name will be submitted to CIRC. Without further inquiries, CIRC would } \\
\text { not be aware of a potential mismatch between the complexity of the } \\
\text { insurance company and the experience of the responsible auditor. It is } \\
\text { recommended, that CIRC should request more detailed information on the } \\
\text { background and function of the external auditor. Such approach would be } \\
\text { more in line with the general attitude to control within the regulatory } \\
\text { approach. } \\
\text { CIRC maintains high requirements for the suitability of key personnel. } \\
\text { The growth of the insurance market and the demand for highly qualified } \\
\text { and experienced management skills should be monitored. Further } \\
\text { development of the market should not be limited by the supply of suitable } \\
\text { personnel or worse, lead to undesirable compromises. Hence, CIRC } \\
\text { should ensure that a general awareness exists on the need of suitable } \\
\text { output from universities and professional bodies and should encourage } \\
\text { insurers to facilitate adequate training courses. }\end{array}$ \\
\hline $\begin{array}{l}\text { ICP } 8 \text { - Changes in control and } \\
\text { portfolio transfers }\end{array}$ & $\begin{array}{l}\text { CIRC must develop a suitable regulation to facilitate the transfer of } \\
\text { portfolios. Specific attention must be given to the transfer of liabilities, the } \\
\text { adequacy of reserves and technical provisions, the ability of the recipient } \\
\text { of the portfolio to meet requirements on suitability, license and internal } \\
\text { control. A transfer should not be dependent upon the acceptance of } \\
\text { policyholders or beneficiaries but timely notification of the intended } \\
\text { transfer should be provided to them. A transfer of life insurance business } \\
\text { should require the separation of the existing life policy business from the } \\
\text { transferred business in the recipient's company. }\end{array}$ \\
\hline ICP 9 - Corporate governance & $\begin{array}{l}\text { CIRC has issued sufficient regulation to ensure that corporate governance } \\
\text { is recognized as one of the key fundamentals of the Chinese supervisory } \\
\text { framework. Given the size of the country itself, the size of the market } \\
\text { (already large at this early phase of its development) and the low quantity } \\
\text { of insurance companies, regulating governance and enforcing its } \\
\text { application is paramount to a sound and safe market environment. } \\
\text { Preparatory research for this mission, interviews with insurance } \\
\text { companies and further conversations have raised concerns on the } \\
\text { robustness of the system against corruption, including bribery. It is } \\
\text { believed that a stronger effort to reduce corruption is needed. This would } \\
\text { especially address the distribution of insurance products, the handling of } \\
\text { insurance claims, general trustworthiness of the legal system, accessibility } \\
\text { of courts and protection of consumer rights. }\end{array}$ \\
\hline ICP 10 - Internal controls & $\begin{array}{l}\text { The focus on internal control is rules based and sufficiently detailed. } \\
\text { Reports to CIRC, both HQ and bureaus, are regularly and timely. Minutes }\end{array}$ \\
\hline
\end{tabular}




\begin{tabular}{|c|c|}
\hline & $\begin{array}{l}\text { of the various committees are submitted and analyzed. } \\
\text { CIRC could consider asking external auditors to include in their regular } \\
\text { audits an inspection of the risk managements systems and the internal } \\
\text { control procedures at least for the large companies, where a full scope } \\
\text { inspection cycle of five year might be too infrequent. }\end{array}$ \\
\hline ICP 11 - Market analysis & $\begin{array}{l}\text { The monthly submission required by CIRC is very substantive in size and } \\
\text { level of detail. It is unclear to what extend the amount of data can actually } \\
\text { be meaningfully analyzed in time: especially as data on technical } \\
\text { performance usually does not vary significantly in that short a time period. } \\
\text { CIRC should consider whether the monthly submission should be } \\
\text { significantly reduced. Certain technical performance data could be } \\
\text { required on a quarterly basis as is already the case for reinsurers. }\end{array}$ \\
\hline $\begin{array}{l}\text { ICP } 12 \text { - Reporting to } \\
\text { supervisors and off-site } \\
\text { monitoring }\end{array}$ & $\begin{array}{l}\text { CIRC has established a comprehensive classification system and can now } \\
\text { allocate supervisory resources efficiently according to the risk profile of } \\
\text { each supervised entity. The criteria within the classification system could } \\
\text { be further enhanced to also reflect the technical performance of life } \\
\text { business through the usage of embedded value accounting. Moreover, } \\
\text { impact and probability of risks should be better reflected. }\end{array}$ \\
\hline ICP 13 - On-site inspection & $\begin{array}{l}\text { On-site inspections should also be used to verify whether assumptions } \\
\text { made off-site turned out to be accurate. There are merits in concentrating } \\
\text { inspections in one department. However, the experience and } \\
\text { understanding of how the insurance company operates and what its } \\
\text { processes and business model are, is very important for all of CIRC's staff } \\
\text { involved in the operational supervisory process. }\end{array}$ \\
\hline $\begin{array}{l}\text { ICP } 14 \text { - Preventive and } \\
\text { corrective measures }\end{array}$ & $\begin{array}{l}\text { The prevention process is thorough and comprehensive. It almost contains } \\
\text { more rules than needed given the business culture explained above and } \\
\text { has to be enforced in all areas, especially the prudential principles need to } \\
\text { be enforced more rigorously. Corrective actions are solvency based and } \\
\text { there is evidence of forbearance. }\end{array}$ \\
\hline \multicolumn{2}{|l|}{$\begin{array}{l}\text { ICP } 15 \text { - Enforcement or } \\
\text { sanctions }\end{array}$} \\
\hline $\begin{array}{l}\text { ICP } 16-\text { Winding-up or exit } \\
\text { from the market }\end{array}$ & $\begin{array}{l}\text { Specific regulation under which a voluntary exit from the market via run } \\
\text { off (for non life insurers) or portfolio transfer/ merger can be facilitated } \\
\text { still needs to be produced. This is relatively urgent given current market } \\
\text { conditions including the single insurer rule. Portfolio transfers should be } \\
\text { subject to actuarial clearance and supervisory approval but not } \\
\text { policyholder approval. }\end{array}$ \\
\hline $\begin{array}{l}\text { ICP } 17 \text { - Group-wide } \\
\text { supervision }\end{array}$ & $\begin{array}{l}\text { The Chinese market has been developed with a distinct aim to limit and } \\
\text { restrict the quantity of companies in order to maintain manageable levels. } \\
\text { China already ranks as the six largest insurance markets in the world. } \\
\text { Most of the developed markets within the top } 10 \text { would have at least three } \\
\text { times the quantity of companies. It is expected that the role of insurance } \\
\text { groups will become more significant, requiring CIRC to further develop } \\
\text { regulation to facilitate the supervision of insurance groups. This will } \\
\text { certainly involve centralized risk management functions and group } \\
\text { solvency requirements allowing for diversification. }\end{array}$ \\
\hline
\end{tabular}




\begin{tabular}{|c|c|}
\hline $\begin{array}{l}\text { ICP } 18-\text { Risk assessment and } \\
\text { management }\end{array}$ & $\begin{array}{l}\text { The implementation of the risk management function requires substantial } \\
\text { efforts from both companies and CIRC. Progress and adequacy of the } \\
\text { systems are not easily measured through off-site monitoring and } \\
\text { supervisory reporting. The cycle for on-site inspections extends to five } \\
\text { years. CIRC should agree to changes in regulation and require adequate } \\
\text { audited reports for at least those companies with substantial market share } \\
\text { or specific exposures. }\end{array}$ \\
\hline ICP 19 - Insurance activity & $\begin{array}{l}\text { The insurance activity is sufficiently well defined. CIRC assumes a high } \\
\text { level of control over the market. Limitations on the ability of the } \\
\text { insurance companies to further develop products or business procedures in } \\
\text { order to gain competitive advantage exist. } \\
\text { CIRC should prevent insurers from taking loans and pledging assets } \\
\text { covering capital requirements or technical provisions. } \\
\text { Product approval and off-site monitoring must lead to early recognition of } \\
\text { shortfalls and must lead to rectification plans with immediate effect and } \\
\text { short response times. }\end{array}$ \\
\hline ICP 20 - Liabilities & $\begin{array}{l}\text { CIRC should not allow insurers to maintain inadequate reserve levels. } \\
\text { Policyholder and beneficiaries must expect CIRC to ensure minimum } \\
\text { reserve levels at all times. Product approval and off-site monitoring must } \\
\text { lead to early recognition of shortfalls and must lead to rectification plans } \\
\text { with immediate effect and short response times. CIRC should also prevent } \\
\text { insurers from writing new business for as long as reserve levels are } \\
\text { inadequate. CIRC should prevent egregious cross-subsidizing of policies. } \\
\text { The introduction of new accounting standards should have been applied } \\
\text { with precautionary measures. Effects from re-measurement should have } \\
\text { been deferred to other comprehensive income as part of equity and should } \\
\text { have not been disbursed to shareholders for at least three years. }\end{array}$ \\
\hline ICP 21 - Investments & $\begin{array}{l}\text { Chinese insurers face a very narrow range of investment categories and } \\
\text { opportunities to invest their assets. Whilst quantitative and qualitative } \\
\text { restrictions appear to ensure a safe and sound environment, it also overly } \\
\text { exposes the insurers to domestic interest rate and credit risks. As } \\
\text { described under ICP 22, CIRC should issue regulations to allow for macro } \\
\text { and portfolio hedging CIRC has to assume that investment management } \\
\text { must be capable of engaging in hedging activities. Analysis of the } \\
\text { financial performance of Chinese insurers has shown a strong volatility of } \\
\text { the investment income. The performance of traditional and with profit } \\
\text { products in particular depend on reliable and stable investment returns. } \\
\text { Insurers should have more flexibility to achieve those returns. Micro } \\
\text { hedges are deemed to be insufficient and not flexible enough to provide } \\
\text { suitable protection. } \\
\text { CIRC should issue distinct regulations governing the quality of assets } \\
\text { covering technical provisions and capital requirements. For those } \\
\text { categories, related party transactions should not be permitted. }\end{array}$ \\
\hline $\begin{array}{l}\text { ICP } 22 \text { - Derivatives and } \\
\text { similar commitments }\end{array}$ & $\begin{array}{l}\text { At the time of the assessment, insurers as a whole were not allowed to } \\
\text { write or purchase derivatives. Thus there is limited scope to hedge } \\
\text { investment risks. However selected exceptions were granted to six }\end{array}$ \\
\hline
\end{tabular}




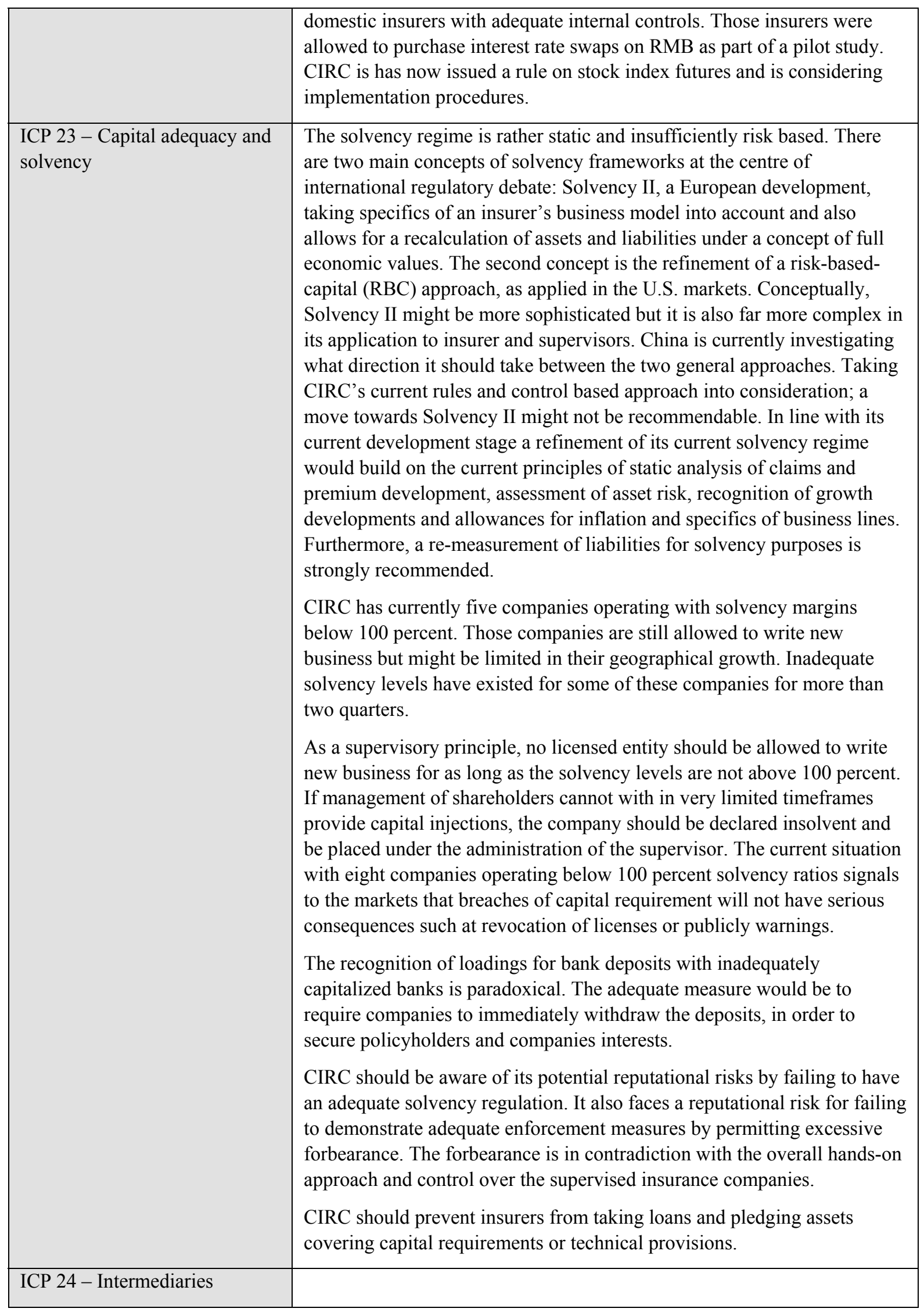




\begin{tabular}{|l|l|}
\hline ICP 25 - Consumer protection & $\begin{array}{l}\text { CIRC could introduce the disclosure of complaints per company to further } \\
\text { enhance companies' discipline and to increase the awareness on customer } \\
\text { satisfaction. The complaint function should be moved from the insurance } \\
\text { association to a more independent source to enhance creditability of the } \\
\text { process. }\end{array}$ \\
\hline $\begin{array}{l}\text { ICP 26- Information, } \\
\text { disclosure and transparency } \\
\text { towards markets }\end{array}$ & $\begin{array}{l}\text { Since the regulation on disclosure only recently has been introduced, a } \\
\text { review process should be established to allow for modification and } \\
\text { refinements within a timeframe of the next two years. }\end{array}$ \\
\hline ICP 27 - Fraud & $\begin{array}{l}\text { CIRC has increased substantially its efforts against fraud. Staffing levels } \\
\text { should be increased to address fraud at a more appropriate level. } \\
\text { Corruption and bribery are a concern. A stronger effort and adequate staff } \\
\text { will allow CIRC to contribute more effectively to an overall enhancement } \\
\text { of market discipline in the financial sector. }\end{array}$ \\
\hline $\begin{array}{l}\text { ICP 28 -Anti-money- } \\
\text { financing of terrorism }\end{array}$ & $\begin{array}{l}\text { Currently the share of responsibility for AML between PBC and CIRC } \\
\text { and the lack of active involvement and influence of the CIRC over the } \\
\text { process results in a significant reputational risk to the CIRC, particularly } \\
\text { as the current system as operated by PBC is not complete. A clear } \\
\text { accountability is needed to respond in a timely manner to the specifics of } \\
\text { AML. The rather opaque involvement of CIRC in conjunction with the } \\
\text { lack of influence and involvement on inspections and sanctions is not } \\
\text { satisfactory. A decision is needed as to where the AML function will be } \\
\text { housed and then to ensure it is carried out effectively. If it is not with the } \\
\text { CIRC, then it is essential that CIRC be adequately informed so as to } \\
\text { properly supervise the sector. In addition the thresholds for the reporting } \\
\text { of suspicious transactions should be more in line with those with income } \\
\text { levels. }\end{array}$ \\
\hline
\end{tabular}

\section{Key Recommendations}

\section{The assessment team found several improvement opportunities, summarized in the Table below:}

Table 17. China: Recommended Action Plan to Improve Observance of the Insurance Core Principles

\begin{tabular}{|l|l|}
\hline \multicolumn{1}{|c|}{ Principle } & \multicolumn{1}{|c|}{ Recommended Action } \\
\hline ICP 2 - Supervisory objectives & $\begin{array}{l}\text { Financial stability, consumer protection and fair competition could be } \\
\text { translated into operational goals and form the basis for a mission } \\
\text { statement of CIRC. That statement could also help new staff to engage } \\
\text { more quickly with the authority's tasks. } \\
\text { CIRC's second objective and related responsibilities for the } \\
\text { development of the domestic market (as implemented) are rather } \\
\text { unique for a mainstream supervisor. It is recommended the two } \\
\text { mandates be separated and a suitable agency be identified to take } \\
\text { ownership of the developmental, commercial and social objectives. } \\
\text { This would help to ensure the supervisor has a clear objective and is } \\
\text { able to undertake its role without conflict. }\end{array}$ \\
\hline
\end{tabular}




\begin{tabular}{|c|c|}
\hline ICP 3 - Supervisory authority & $\begin{array}{l}\text { The staffing levels of CIRC are not adequate. In particular, the areas } \\
\text { of off-site monitoring, inspection, international cooperation, } \\
\text { accounting and auditing and the staffing levels of key units in the } \\
\text { insurance bureaus should be substantially strengthened through } \\
\text { increased suitable staffing. }\end{array}$ \\
\hline ICP 6 - Licensing & $\begin{array}{l}\text { The licensing process should not be restricted to control the market } \\
\text { entry of insurers but must also facilitate changes of insurers' strategy } \\
\text { and ability to underwrite business. CIRC must ensure that a company } \\
\text { will be prohibited from writing new policies but still is liable and able } \\
\text { to administer its current liabilities and contracts. }\end{array}$ \\
\hline $\begin{array}{c}\text { ICP } 8 \text { - Changes in control and } \\
\text { portfolio transfers }\end{array}$ & $\begin{array}{l}\text { CIRC must develop a suitable regulation to facilitate the transfer of } \\
\text { portfolios. Specific attention must be given to the transfer of } \\
\text { liabilities, the adequacy of reserves and technical provisions, the } \\
\text { ability of the recipient of the portfolio to meet requirements on } \\
\text { suitability, license and internal control. } \\
\text { A transfer should not be dependent upon the acceptance of } \\
\text { policyholders or beneficiaries but timely notification of the intended } \\
\text { transfer should be provided to them. } \\
\text { A transfer of life insurance business should require the separation of } \\
\text { the existing life policy business from the transferred business in the } \\
\text { recipient's company. }\end{array}$ \\
\hline $\begin{array}{l}\text { ICP } 14 \text { - Preventative and corrective } \\
\text { measures }\end{array}$ & $\begin{array}{l}\text { Corrective actions in line with Section } 6 \text { of the insurance law need to } \\
\text { be applied more vigorously to insurers breaching solvency. }\end{array}$ \\
\hline $\begin{array}{l}\text { ICP } 16 \text { - Winding-up or exit from the } \\
\text { market }\end{array}$ & $\begin{array}{l}\text { CIRC should develop specific regulation under which an exit from the } \\
\text { market can be facilitated via portfolio transfer or merger and which } \\
\text { allows for run off of non life business. }\end{array}$ \\
\hline ICP 20 - Liabilities & $\begin{array}{l}\text { Product approval and off-site monitoring must lead to early } \\
\text { recognition of shortfalls and must lead to rectification plans with } \\
\text { immediate effect and short response times. CIRC should also prevent } \\
\text { insurers from writing new business for as long as reserve levels are } \\
\text { inadequate. CIRC has to prevent cross-subsidizing of policies. } \\
\text { The introduction of new accounting standards should have been } \\
\text { applied with precautionary measures. Impacts from re-measurement } \\
\text { should have been deferred to other comprehensive income as part of } \\
\text { equity and should not have been available to shareholders as } \\
\text { dividends for at least three years. }\end{array}$ \\
\hline $\begin{array}{l}\text { ICP } 23 \text { - Capital adequacy and } \\
\text { solvency }\end{array}$ & $\begin{array}{l}\text { CIRC has to facilitate the rectification of solvency margins for five } \\
\text { companies operating with solvency margins below } 100 \text { percent. As a } \\
\text { supervisory principle, no licensed entity should be allowed to write } \\
\text { new business for as long as the solvency levels are not above } 100 \\
\text { percent. }\end{array}$ \\
\hline
\end{tabular}




\begin{tabular}{|l|l|}
\hline & $\begin{array}{l}\text { If management or shareholders cannot with in very limited timeframes } \\
\text { arrange for capital injections, the company should be declared } \\
\text { insolvent and be directed under the administration of the supervisor. } \\
\text { The recognition of loadings for bank deposits with inadequately } \\
\text { capitalized banks is paradoxical. The adequate measure would be to } \\
\text { require companies to immediately withdraw the deposits, in order to } \\
\text { secure policyholders and companies interests. }\end{array}$ \\
\hline $\begin{array}{ll}\text { ICP 28 - Anti-money laundering, } \\
\text { combating the financing of terrorism }\end{array}$ & $\begin{array}{l}\text { A clear accountability is needed to respond in a timely manner to the } \\
\text { specifics of AML. The rather opaque involvement of CIRC in } \\
\text { conjunction with the lack of influence and involvement on inspections } \\
\text { and sanctions is not satisfactory. A decision is needed as to where the } \\
\text { AML function will be housed and then to ensure it is carried out } \\
\text { effectively. } \\
\text { If it is not with the CIRC, then it is essential that CIRC be adequately } \\
\text { informed so as to properly supervise the sector. }\end{array}$ \\
\hline
\end{tabular}

\section{F. Authorities' Response}

140. We appreciate the FSAP assessors' recognition of what the CIRC has achieved in supervisory enforcement, categorized supervision, market analysis, regulatory cooperation, information sharing, and consumer protection.

141. The assessors have also acknowledged the CIRC's efforts and progress made in corporate governance, internal control, group supervision, solvency regulation, risk management, and off-site supervision.

142. The assessors understand that, in the few areas where full observance has not yet been achieved, the CIRC has taken appropriate regulatory measures and approaches based on China's own conditions including its unique market environment and development stage. The regulatory philosophy we follow is consistent with IAIS's core principles for insurance regulation. We focus on prudential supervision, emphasize risk prevention, make vigorous efforts to maintain the market order and to protect consumer interests, thus we have effectively maintained the stability of the market.

143. As a response to the assessor's comment on solvency supervision, the CIRC attaches great importance to this task. Drawing upon the solvency supervisory standards of the European Union (EU) and the U.S., we have established a solvency supervisory system tailored to China's realities. The current system reflects the status quo of China as an emerging market and facilitates the stability of our insurance market. The fact that China's insurance industry remained resilient to the global financial crisis proves the risk-control ability of our solvency supervisory system. Specifically, the current system takes into account the underwriting risk, investment risk, interest rate risk, credit risk and asset liability matching risk of insurance companies. The system has the basic features of a risk-based 
solvency supervisory system and provides a good foundation for the transition to a comprehensively risk-based system. Currently the CIRC is studying the solvency supervisory systems in the world and dedicated to further improve its own system.

144. With respect to AML, it should be seen that China has its unique mechanism for this function. As provided by China's Anti-Money Laundering Law, the PBC leads the work of AML and other authorities should actively assist it in its work. The division of responsibilities among relevant authorities is clear. The CIRC bears its share of responsibility and carries it out in its daily supervision. In practice, insurance institutions observe the AML rules put in place by both the PBC and the CIRC. They have established complete internal controls and other relevant measures for this purpose, and are actively carrying out the AML obligations. In order to supervise the risks of insurance companies, the CIRC carries out inspections on their internal controls, which include AML controls, and exchanges information with the PBC (the AML Bureau) through adequate channels.

145. To address the emerging issues and changes as market develops, the CIRC has been improving its rules and regulations and striving to enhance effective supervision. Since the newly revised Insurance Law was promulgated on October 1, 2009, the CIRC has formulated and introduced new rules and revised old rules covering personnel qualification, information disclosure, asset management, equity management and other aspects. Efforts have been made to further enhance industry order, strengthen corporate governance and internal control, promote risk management capabilities of insurance companies, and fundamentally safeguard the legitimate interests of the stakeholders.

146. We also appreciate the recommendations of the assessors. We will carefully study these recommendations and take them into consideration in our regulatory practices and the formulation of rules and regulations. 


\section{ANNEX III: OBSERVANCE OF FinANCIAl SECTOR STANDARDS AND CODES-IOSCO ObJeCtives ANd Principles of SeCurities Regulation: A SumMary}

\section{A. Introduction}

147. This assessment was performed in 2010 as part of the FSAP of China. The assessment used the IOSCO Objectives and Principles of Securities Regulation (May 2003) and the Methodology for Assessing Implementation of the IOSCO Objectives and Principles of Securities Regulation (February 2008). It was assisted by a self-assessment prepared by the CSRC, public information contained on the CSRC website and the websites of other entities in China, and a review of relevant Chinese laws and regulations.

\section{B. Institutional and Market Structure-Overview}

148. The CSRC performs centralized supervision and regulation of the securities and futures markets on the Chinese mainland. China has adopted a sectoral supervision model for its financial industry, with securities market under separate supervision by CSRC. In accordance with the laws, and as duly authorized by the SC, the CSRC performs centralized and unified supervision and regulation of the nation's securities and futures markets, with the aim both of promoting soundness in the markets and promoting market development.

\section{Under this arrangement, the CSRC headquarters undertake the following} responsibilities: formulating, amending and revising rules and regulations concerning the securities and futures markets, making market development plans, processing key reviews and approvals, guiding and coordinating efforts in risk disposals of insolvent securities or futures companies, organizing investigation of and enforcement against material violations and non-compliances, and guiding, inspecting, promoting and coordinating the nation-wide regulatory efforts. Under the supervision of the CSRC headquarters, its 36 regional offices are responsible for front-line supervision within their respective jurisdictions.

150. SROs are critical components of the regulatory system. To supplement the regulatory activities of the CSRC, SROs including the stock and futures exchanges, SD\&C, Securities Association of China (SAC), China Futures Association (CFA) are responsible for self-regulation and front-line supervision over securities/futures trading activities of their members or listed companies. In addition, the National Association of Financial Market Institutional Investors (NAFMII) was established in 2007 to oversee the trading of fixed term instruments through the inter-bank lending and bond market.

\section{The CSRC is subject to the general authority of the SC which appoints the}

Chairman. The Chairman holds Minister rank in the Chinese Government, on the same level as the Chairmen of the CBRC and CIRC. The responsibilities of the CSRC are clearly articulated in the Securities Law and the Law of the Peoples Republic of China on Securities 
Investment Funds (henceforth the Fund Law) and in a series of related laws that have expanded the duties and powers of the CSRC.

152. The CSRC has broad regulatory authority over the stock and futures exchanges, the SD\&C and other clearing and settlement institutions, securities companies, futures companies, and collective investment scheme (CIS) operators. Other governmental agencies in China have responsibility for discrete regulatory functions that are included in the IOSCO principles. The major authorities are described below. Others are mentioned in the detailed principle-by-principle assessment. Of particular relevance to the IOSCO assessment the Peoples Bank of China is primarily responsible in China for AML regulation, guiding and organizing the AML work of the financial sector and regulators including the CSRC and monitoring relevant fund flows. It also regulates the inter-bank lending market and inter-bank bond market, and was the Government entity which provided seed funding for the Securities Investment Protection Fund (SIPF), which was established to assist with the resolution of a large number of failed securities companies and compensate investors earlier this decade.

153. The SSE was established in 1990. At the end of 2009, SSE had a total of 870 listed companies, 1,351 listed stocks with US\$2.78 trillion market capitalization, and US\$ 5.22 trillion stock turnover. It has 107 securities firm members and seven domestic and overseas special members. Securities listed on SSE are traded through an electronic bidding system with automatic price matching according to price and time priority through the SSE's mainframe. The Shenzhen Stock Exchange was also founded in 1990, and has a Main Board, SME Board, Growth Enterprise Board (GEB) and the stock transfer agent system. The exchanges' trading and business rules are subject to the approval of the CSRC.

\section{There are three commodities futures exchanges and one financial futures} exchange in mainland China. These consist of the Shanghai Futures Exchange (SHFE), the Dalian Commodity Exchange (DCE), the Zhengzhou Commodity Exchange (ZCE) and the China Financial Futures Exchange (CFFEX). The CFFEX, which is owned by the other commodity futures exchanges, recently commenced trading in stock index futures, China's first financial derivative contract, and it is intended to launch other market-oriented derivatives such as options and potentially futures and options on treasury bonds and foreign exchange to diversify the financial derivatives market. The commodity exchanges' trading and business rules are subject to the approval of the CSRC.

\section{The SD\&C was founded in 2001 and establishes rules for participants in the} clearing and settlement process, in particular for managing clearing and settlement accounts. The SD\&C is required as a securities registration and clearing institution to establish securities and clearing accounts, clear and settle securities and the cash associated with securities transactions, and distribute entitlements as instructed by the issuer (Article 157 of the Securities Law). It has developed detailed rules to ensure its members' compliance 
with the relevant laws and regulations, including rules related to the administration of securities accounts, administration of clearing participants, and the administration of securities reserve funds, which are subject to the approval of the CSRC. The disciplinary powers include restricting or cancelling the use of participating accounts, and suspending or terminating the clearing participants' clearing rights.

\section{There are two primary types of CIS business in China: securities investment} funds managed by fund managers, and collective asset management business conducted by securities companies. Wealth management products have grown considerably in size in recent years - at the end of 2009 wealth management products of banks totaled US\$ 147.6 billion, of which, investment grade products accounted for more than US\$ 96.4 billion. In addition, some funds, specifically private equity style funds administered through a trust company, are regulated by the $\mathrm{CBRC}$; and some other funds, specifically private equity funds linked to industry development, are regulated by the NDRC.

\section{The SAC and the CFA are national SROs for the securities and futures} industries respectively. They aim to implement self regulation over the securities and futures industry under the centralized supervision and regulation of the CSRC; to serve as a bridge between the government and the securities and futures industries; and to maintain fair competition in the securities and futures industries, promote transparency, fairness and equitability of the market and its healthy and steady development. The SAC and CFA are responsible for frontline supervision of members and under delegation from the CSRC conduct initial qualification examinations for members of the securities and futures industries.

\section{The Chinese securities sector has seen considerable volatility but overall has} grown very quickly, especially in the last five years. At the regulatory level, there have been a number of important regulatory reforms to support the movement towards a more modern capital market. The reform of non-tradable shares introduced a market-based pricing system for so-called non-tradable shares in listed companies closely held by government and semi-government authorities. The securities sector also underwent a significant overhaul in the early part of this decade following widespread solvency problems and misappropriation of funds held on behalf of clients in securities firms and funds management companies. This overhaul included introducing extensive third party custodian requirements for handling client property and risk-adjusted capital requirements for securities firms. These reforms appear to have been successful in providing greater stability to securities firms and in protecting client assets. 


\section{Preconditions for Effective Securities Regulation}

159. The Chinese regulatory regime has adopted a clear set of accounting and auditing standards. These are well advanced in the process of converging with IFRS and IAS and which are of high and internationally acceptable quality. The accounting and audit profession is growing and developing in professional competence and capacity. Similarly, the private legal profession and the capacity of the judicial system to handle commercial disputes has also been developing, but the involvement of institutional and retail shareholders in corporate governance is less well developed. As a result, more of the burden of dealing with commercial failures that involve regulatory breaches falls onto the CSRC than in jurisdictions with more active shareholders and easier access to litigation to resolve serious disputes.

160. There are various levels of law making within China. The highest levels are laws developed by the National People's Congress (NPC) or its Standing Committee, which include the Securities Law and the Fund Law. At the next level there are Administrative Regulations promulgated by the SC subject to the Constitution and other laws. At a third level, there are rules and regulations developed and promulgated by the CSRC in accordance with (and subordinate to) the laws and regulations of the SC. These CSRC rules and regulations may be described as "Tentative" or "Trial" where they are new regulatory requirements or relate to innovations, but they have the same status as other rules or regulations promulgated by the $\mathrm{CSRC}$ and are enforceable as such.

161. In some cases the strict letter of the law has been buttressed by opinions issued by the Supreme People's Court, and these appear to have been effective. For example, the Supreme Court has issued opinions that establish the legality and enforceability of Article 139 of the Securities Law and similar provisions which establish that in the insolvency of a securities firm funds held on behalf of a client shall not be treated as part of the liquidation but remain the property of the client: see the Circular of the Supreme People's Court on Relevant Issues Concerning the Freeze and Transfer of Funds in the Clearing Accounts of Stock or Futures Exchanges (1997). In the bankruptcy case of Minfa Securities, the insolvency administrator had proposed that around US\$ 11.29 million worth of clients' transaction settlement assets it had secured should be regarded as property in the liquidation. The Supreme People's Court ruled that such funds did not belong to the liquidation and should be used to cover the shortfall in clients' transaction settlement funds.

\section{Main Findings}

162. As noted above the Chinese securities and futures industry and their regulation has undergone considerable development since the establishment of the CSRC less than 20 years ago. Reforms in recent years, in particular the non-tradable shares reforms, the introduction of stock index futures trading in 2010, and the overhaul of third party custodian 
and risk-based net capital requirements for securities firms, have enhanced the transparency of the market, broadened the range of available products and improved the financial soundness of intermediaries, to the considerable benefit of investor protection in China. These reforms have been carefully planned and implemented, and have been welcomed by market participants. They provide evidence of an active and strategic approach to regulation of the Chinese securities markets on the part of the CSRC and other authorities. These reforms have built on an extensive set of regulatory provisions which have drawn on the experience of other more developed securities markets, the United States and Hong Kong amongst others. There are few areas in which the regulatory framework needs further work in order to fully meet the IOSCO standards. Some of the areas for improvement identified in this report look to further improvements in the legal and accounting environment.

163. The Regulator: The responsibilities of the regulator responsible for securities regulation, the CSRC, are clearly set out in three primary pieces of legislation: the Securities Law, the Fund Law, and the Regulations on the Administration of Futures Trading. A sectoral approach to regulation applies in China, under which the $\mathrm{CBRC}$ regulates banking and banking institutions and the CIRC regulates insurance and insurance companies. Where banking or insurance companies engage in securities type activities, such as establishing and distributing wealth management products, the CBRC and CIRC have corresponding regulatory authority. In addition, some entities such as hedge funds and private equity funds are either not regulated or lightly regulated by other entities. In the interests of avoiding regulatory arbitrage, products performing a similar function should be regulated in a similar way, and the authorities should pay particular attention to wealth management products in this regard. With respect to hedge funds and private equity funds, the IOSCO Principles as in force at the date of this assessment do not require their regulation. However, given the rapid growth in these funds (especially private equity funds) and the potential for them to be used as retail investment vehicles, the authorities should consider placing them under the regulatory authority of the CSRC. The CSRC has power to develop rules and regulatory documents within the authority granted by laws and the Legislation Law for the purpose of performing its functions. It operates in practice as an independent agency free from political or commercial interests, but as a SC administrative organ it is required to follow civil service staffing and budgetary procedures which do not necessarily keep pace with developments in the regulated population, and some greater flexibility in this regard would help it discharge its regulatory functions. The CSRC's budget is not sufficient to enable it to exercise its powers and responsibilities, given the rapid growth in the market and the nature of other market discipline mechanisms at this stage of China's capital market development. There is considerable attention devoted to investor education, but significant further efforts are required to address retail investors' understanding of the market and risk. 
164. SROs: The regulatory arrangements in China place significant reliance on SROs to perform regulatory functions, under the authority and supervision of the CSRC. These SROs include the exchanges, clearing and settlement institutions, and industry associations. Given the growth of the Chinese capital markets and in particular in listed companies, retail investors and regulated entities, the SROs will need to give continued attention and resources to their regulatory functions. While the CSRC exercises significant authority and oversight over the SROs and communicates regularly with them, it should consider instituting a formal program whereby it conducts regular comprehensive inspections of the exchanges.

165. Enforcement: The CSRC has comprehensive powers related to inspection, investigation, surveillance and enforcement, and in particular has a useful power under which it can freeze assets by administrative order for the purpose of safeguarding them during the completion of an investigation. The laws and regulations provide a range of private rights of action for compensation and other action in the event of non-compliance causing damage to investors, but the legal system (in particular, the commercial courts) and the effect of market discipline provided by institutional investors and other participants on corporate governance is not as significant in China as in other jurisdictions. While private enforcement action is not a substitute for public enforcement action, supervision and regulation, it can supplement and support it. In combination, these factors undermine the capacity of private legal action to have a meaningful practical impact on compliance. Given the very high level of retail participation in the market, this means that the CSRC and authorities a greater share of the burden of ensuring compliance than in other markets. Arrangements for surveillance of abnormal trading are extensive and some substantial enforcement actions have been taken to deter market manipulation and insider trading, but there is need for continued attention and resources to enforce the laws with respect to illegal investment activity (including Ponzi schemes and bucket shops).

166. Cooperation: The CSRC has the ability to share public and non-public information with both domestic and foreign counterparts without other external process, for the purpose of performing regulatory and supervisory functions. The CSRC has established formal information sharing arrangements with the CBRC and CIRC, and with a large number of foreign securities and futures regulators. The CSRC and other domestic regulators should give more consideration to the efficacy of their cooperative arrangements, especially with respect to ensuring that products or activities that have a similar function are regulated similarly to avoid the potential for regulatory arbitrage. The CSRC is a signatory to the IOSCO Multilateral Memorandum of Understanding on Exchange of Information (MMOU) and actively makes and responds to requests for information and assistance with foreign regulators.

167. Issuers: The regulatory regime contains detailed requirements and follow-up mechanisms of the CSRC and exchanges for the disclosure of comprehensive information about financial results and risks of listed companies and other investment offers. The CSRC 
should promulgate a clearer requirement that advertising refer potential investors to the prospectus, similar to the requirement for CIS. The regulatory regime adequately addresses the rights and equitable treatment of shareholders, including with respect to mergers. However, the timeframes for the provision of annual and semi-annual financial statements, and the thresholds for reporting changes in substantial shareholdings, appear long by the standards in place in other major markets and should be reviewed. The regulatory regime has adopted a clear set of accounting and auditing standards which are well advanced in the process of converging with IFRS and which are of high and internationally acceptable quality. Continued attention will need to be given to the development of the private accounting and audit profession in China, and the level of fines for the provision of false or misleading financial statements should be reconsidered, to ensure that financial statements are professionally prepared and audited.

168. CIS: There are clear regulatory requirements for those that wish to operate or market a CIS, which provide reasonable entry requirements, ongoing eligibility and conduct rules, and requirements aimed at managing conflicts of interest. The regulatory regime adequately provides rules governing the legal form and structure of CIS. Segregation and protection of client assets is assured through a mandatory system of third party custodianship, and there are comprehensive disclosure requirements to enable a prospective investor to evaluate the suitability and prospects of the scheme. There are adequate provisions governing valuation requirements including audit requirements, and specific requirements concerning the pricing of subscription to or redemptions from funds. However, the provisions related to the professional qualifications and experience of fund managers should be reviewed as the industry develops. Given the high level of retail participation in the market, it is very important that all information should be provided in clear and simple language, and the CSRC will need to monitor this closely. The CSRC should be wary of the potential for unlicensed CIS activity, such as Ponzi schemes, to arise in the Chinese market and give attention to detecting and deterring it.

169. Market Intermediaries: The Chinese regulatory regime requires that market intermediaries must be licensed with the CSRC, and are subject to initial and ongoing capital and experience and qualifications requirements. The CSRC should consider amending its rules on investment consultants to require such consultants to disclose in detail to clients their personal backgrounds and career records, working experience, compliance record, investment strategies and fee structure, as the development of an independent financial advising capacity can be an important part of markets with significant levels of retail participation. The regulatory regime in China provides appropriate prudential controls with respect to market intermediaries and that relate to the risks involved in the particular businesses that market intermediaries undertake. The initial registered capital requirements and the ongoing risk-based net capital requirements provide a significant level of prudential buffer in respect of risks. As the system of risk-based net capital is relatively new, the CSRC should continue to monitor it carefully to ensure that it captures all relevant risks. The 
regulatory regime requires market intermediaries to have an internal risk management function and controls to protect the interests of clients. The CSRC could consider some extensions of technical aspects of the regulatory regime to cover existing parts of the industry, such as whether the concept of suitability included in the requirements for trading in stock index futures should be more generally applied, in light of the broad retail participation in Chinese capital markets and the need for investors to be informed about the risks of products appropriate to their circumstances, and whether some form of third party custodianship should apply to the management of client margins currently held by futures companies. The Chinese regulatory regime makes adequate provision for dealing with the failure of an intermediary, building on experience with significant failures of securities companies in the early part of this decade. However, the authorities should consider altering the threshold in the relevant regulations, that in the absence of a failure to observe a rectification order that the failure "severely threaten the order" of the market, to ensure that the CSRC can act promptly before the problem becomes too large.

170. Secondary Markets: The Chinese regulatory regime makes adequate provision for authorization and oversight of entities which wish to operate a stock or futures exchange, covering the exchanges themselves, admission of products to trading, trading information, and execution procedures. The regulatory regime provides for market authorities to monitor the risk of large and open positions that pose a risk to the market or clearing. In the event of default, there are procedures in place to ensure that the problem is isolated and does not affect other market participants, and for apportioning any loss appropriately. While CSRC staff maintain regular dialogue with the stock exchanges especially on listed company disclosure and trading issues, and membership and trading rules of the exchanges are subject to approval by the CSRC, instituting a formal program whereby it conducts regular comprehensive on-site inspections like for other exchanges should also be considered. The CSRC and exchanges have implemented systems for the ongoing surveillance and supervision of trading to ensure market integrity, and have devoted considerable human and technological resources to detecting and deterring insider trading and market manipulation. At the same time, given the size of the market, its rapid growth, and the enormous interest generated by new listings, the number of abnormal trades detected and on which action is taken seems low. The CSRC should consider some extra and continuing efforts to detect and deter unfair trading practices. 
Table 18. China: Summary of Observance of the IOSCO Principles

\begin{tabular}{|c|c|}
\hline Principle & Findings \\
\hline $\begin{array}{l}\text { Principle } 1 . \text { The responsibilities of } \\
\text { the regulator should be clearly and } \\
\text { objectively stated }\end{array}$ & $\begin{array}{l}\text { The responsibilities of the regulator responsible for securities } \\
\text { regulation, the CSRC, are clearly set out in three primary laws: the } \\
\text { Securities Law, the Fund Law, and the Regulations on the } \\
\text { Administration of Futures Trading. The CSRC has power to develop } \\
\text { rules and regulatory documents within the authority granted by laws } \\
\text { and the Legislation Law for the purpose of performing its functions. } \\
\text { It is required to follow the legal principles established by the } \\
\text { Legislation Law and the Constitution of the Peoples Republic of } \\
\text { China, including principles of transparency. In practice, the CSRC } \\
\text { has developed several rules, regulations and statement of guidance } \\
\text { or opinion related to its functions, and market participants express } \\
\text { satisfaction with the transparency of the consultation process. } \\
\text { A sectoral approach to regulation applies in China, under which the } \\
\text { CBRC regulates banking and banking institutions and the CIRC } \\
\text { regulates insurance and insurance companies. Where such } \\
\text { institutions engage in securities type activities, such as establishing } \\
\text { and distributing wealth management products, the CBRC and CIRC } \\
\text { have corresponding regulatory authority. There is potential for gaps } \\
\text { and inequities to arise where products with similar characteristics } \\
\text { are not regulated in the same manner, so a review of the } \\
\text { requirements across the banking, insurance and securities sectors } \\
\text { with respect to wealth management products should be conducted to } \\
\text { ensure consistent regulatory approaches and avoid any unjustified } \\
\text { differential treatment. }\end{array}$ \\
\hline $\begin{array}{l}\text { Principle } 2 \text {. The regulator should be } \\
\text { operationally independent and } \\
\text { accountable in the exercise of its } \\
\text { functions and powers }\end{array}$ & $\begin{array}{l}\text { The CSRC operates in practice as an independent agency free from } \\
\text { political or commercial interests. The reforms that it has introduced } \\
\text { in recent years, including the tradable shares reform, introduction of } \\
\text { stock index futures, and reforms aimed at redressing solvency and } \\
\text { conduct problems of securities and fund management companies } \\
\text { provide strong indications of its independence. However, it is not } \\
\text { entirely operationally independent in form from political process. } \\
\text { The Chairman is appointed by the State Council and subject to its } \\
\text { oversight with respect to the operating and governance structure. } \\
\text { The provisions concerning the potential liability of staff should be } \\
\text { made clearer that they do not bear any liability for the bona fide } \\
\text { discharge of their functions and duties and that their protection is } \\
\text { not subject to the discretion of the CSRC. The CSRC's budget is not } \\
\text { sufficient to enable it to exercise its powers and responsibilities, } \\
\text { having regard to the rapid growth in the market and the nature of } \\
\text { other market discipline mechanisms at this stage of China's capital } \\
\text { market development, notwithstanding positive developments in the } \\
\text { accounting and legal framework. There is a strong system of } \\
\text { accountability in place for regulatory and administrative decisions. }\end{array}$ \\
\hline $\begin{array}{l}\text { Principle } 3 \text {. The regulator should } \\
\text { have adequate powers, proper } \\
\text { resources and the capacity to perform }\end{array}$ & $\begin{array}{l}\text { The powers and authorities of the CSRC are sufficient, taking into } \\
\text { account the nature of China's capital markets. However, the } \\
\text { CSRC's budget has not kept adequate pace with the growth in }\end{array}$ \\
\hline
\end{tabular}




\begin{tabular}{|c|c|}
\hline Principle & Findings \\
\hline its functions and exercise its powers & $\begin{array}{l}\text { regulated entities and activities and its salaries are a very small } \\
\text { proportion of comparable industry standards, which constrains the } \\
\text { CSRC's ability to retain staff with industry experience. }\end{array}$ \\
\hline $\begin{array}{l}\text { Principle } 4 \text {. The regulator should } \\
\text { adopt clear and consistent regulatory } \\
\text { processes }\end{array}$ & $\begin{array}{l}\text { The CSRC adopts clear and consistent processes in making } \\
\text { regulatory and administrative decisions and provides adequate } \\
\text { opportunities for review. There is some considerable attention given } \\
\text { to investor education, but significant further efforts are required to } \\
\text { address retail investors' understanding of the market and risk. }\end{array}$ \\
\hline $\begin{array}{l}\text { Principle } 5 \text {. The staff of the regulator } \\
\text { should observe the highest } \\
\text { professional standards }\end{array}$ & $\begin{array}{l}\text { The CSRC staff observes high professional standards including } \\
\text { avoiding conflicts of interests and preserving the confidentiality of } \\
\text { information obtained in the course of their duties. The CSRC staff is } \\
\text { subject to legislative provisions and a written code of conduct, } \\
\text { which requirements not to hold to trade in securities and futures, not } \\
\text { to hold any positions in regulated entities, and not to misuse } \\
\text { information. }\end{array}$ \\
\hline $\begin{array}{l}\text { Principle } 6 \text {. The regulatory regime } \\
\text { should make appropriate use of } \\
\text { SROs that exercise some direct } \\
\text { oversight responsibility for their } \\
\text { respective areas of competence and } \\
\text { to the extent appropriate to the size } \\
\text { and complexity of the markets }\end{array}$ & $\begin{array}{l}\text { The regulatory arrangements in China place appropriate and } \\
\text { significant reliance on SROs to perform regulatory functions, under } \\
\text { the authority and supervision of the CSRC. These SROs include the } \\
\text { exchanges, clearing and settlement institutions, and industry } \\
\text { associations. }\end{array}$ \\
\hline $\begin{array}{l}\text { Principle } 7 . \text { SROs should be subject } \\
\text { to the oversight of the regulator and } \\
\text { should observe standards of fairness } \\
\text { and confidentiality when exercising } \\
\text { powers and delegated responsibilities }\end{array}$ & $\begin{array}{l}\text { The SROs are subject to appropriate authorization and oversight } \\
\text { arrangements exercised by the CSRC to provide assurance of their } \\
\text { ability to perform their functions. Given the growth of the Chinese } \\
\text { capital markets and in particular in listed companies and regulated } \\
\text { entities, the SROs will need to give continued attention and } \\
\text { resources to their regulatory functions. The CSRC should consider } \\
\text { instituting a formal program whereby it conducts regular } \\
\text { comprehensive on-site inspections of the exchanges. }\end{array}$ \\
\hline $\begin{array}{l}\text { Principle } 8 . \text { The regulator should } \\
\text { have comprehensive inspection, } \\
\text { investigation and surveillance } \\
\text { powers }\end{array}$ & $\begin{array}{l}\text { The CSRC has comprehensive powers related to inspection, } \\
\text { investigation and surveillance. }\end{array}$ \\
\hline $\begin{array}{l}\text { Principle } 9 . \text { The regulator should } \\
\text { have comprehensive enforcement } \\
\text { powers }\end{array}$ & $\begin{array}{l}\text { The CSRC has comprehensive enforcement powers, and in } \\
\text { particular has a useful power under which it can freeze assets by } \\
\text { administrative order for the purpose of safeguarding them during the } \\
\text { completion of an investigation. The threshold for exercise of its } \\
\text { formal investigation powers should be amended to provide the } \\
\text { regulator with more discretion on when to bring those powers to } \\
\text { bear. The laws and regulations provide a range of private rights of } \\
\text { action for compensation and other action in the event of non- } \\
\text { compliance causing damage to investors, but the legal system (in } \\
\text { particular the commercial courts) and the effect of market discipline } \\
\text { provided by institutional investors and other participants on } \\
\text { corporate governance is not as significant in China as in other }\end{array}$ \\
\hline
\end{tabular}




\begin{tabular}{|c|c|}
\hline & $\begin{array}{l}\text { jurisdictions. In combination, these factors undermine the capacity } \\
\text { of private legal action to have a meaningful practical impact on } \\
\text { compliance. Given the very high level of retail participation in the } \\
\text { market, this means that the CSRC and authorities a greater share of } \\
\text { the burden of ensuring compliance than in other markets. }\end{array}$ \\
\hline $\begin{array}{l}\text { Principle } 10 . \text { The regulatory system } \\
\text { should ensure an effective and } \\
\text { credible use of inspection, } \\
\text { investigation, surveillance and } \\
\text { enforcement powers and } \\
\text { implementation of an effective } \\
\text { compliance program }\end{array}$ & $\begin{array}{l}\text { The CSRC oversees a credible and active inspection, surveillance, } \\
\text { and investigation system which provides adequate oversight of the } \\
\text { market. The CSRC should consider means of encouraging investors } \\
\text { who have a problem to raise their concerns with the CSRC, both to } \\
\text { bolster the market intelligence available from this source and to } \\
\text { boost investor confidence in the regulatory framework. } \\
\text { Arrangements for surveillance of abnormal trading are extensive } \\
\text { and some substantial enforcement actions have been taken to deter } \\
\text { market manipulation and insider trading, but there is need for } \\
\text { continued attention and resources to enforce the laws with respect to } \\
\text { illegal investment activity (including Ponzi schemes and bucket } \\
\text { shops). }\end{array}$ \\
\hline $\begin{array}{l}\text { Principle } 11 . \text { The regulator should } \\
\text { have the authority to share both } \\
\text { public and non-public information } \\
\text { with domestic and foreign } \\
\text { counterparts }\end{array}$ & $\begin{array}{l}\text { The CSRC has the ability to share public and non-public } \\
\text { information with both domestic and foreign counterparts without } \\
\text { other external process, for the purpose of performing regulatory and } \\
\text { supervisory functions. }\end{array}$ \\
\hline $\begin{array}{l}\text { Principle 12. Regulators should } \\
\text { establish information sharing } \\
\text { mechanisms that set out when and } \\
\text { how they will share both public and } \\
\text { non-public information with their } \\
\text { domestic and foreign counterparts }\end{array}$ & $\begin{array}{l}\text { The CSRC has established formal information sharing arrangements } \\
\text { with the CBRC and CIRC, and with a large number of foreign } \\
\text { securities and futures regulators. The CSRC and other domestic } \\
\text { regulators should give more consideration to the efficacy of their } \\
\text { cooperative arrangements, especially with respect to ensuring that } \\
\text { products or activities that have a similar function are regulated } \\
\text { similarly to avoid the potential for regulatory arbitrage. }\end{array}$ \\
\hline $\begin{array}{l}\text { Principle } 13 \text {. The regulatory system } \\
\text { should allow for assistance to be } \\
\text { provided to foreign regulators who } \\
\text { need to make inquiries in the } \\
\text { discharge of their functions and } \\
\text { exercise of their powers }\end{array}$ & $\begin{array}{l}\text { The CSRC is a signatory to the IOSCO MMOU and actively makes } \\
\text { and responds to requests for information and assistance with foreign } \\
\text { regulators. }\end{array}$ \\
\hline $\begin{array}{l}\text { Principle } 14 \text {. There should be full, } \\
\text { timely and accurate disclosure of } \\
\text { financial results and other } \\
\text { information that is material to } \\
\text { investors' decisions }\end{array}$ & $\begin{array}{l}\text { The regulatory regimes contains detailed requirements and follow } \\
\text { up mechanisms of the CSRC and exchanges for the disclosure of } \\
\text { comprehensive information about financial results and risks of listed } \\
\text { companies and other investment offers. The CSRC should consider } \\
\text { promulgating a clearer prohibition on advertising unless it refers } \\
\text { potential investors to the prospectus, similar to the requirement for } \\
\text { CIS. The timeframes for the provision of annual and semi-annual } \\
\text { financial statements appear long by the standards in place in other } \\
\text { major markets and should be reviewed. In addition, continued } \\
\text { attention will need to be given to the development of the private } \\
\text { accounting and audit profession in China, and the level of fines for } \\
\text { the provision of false or misleading financial statements should be } \\
\text { reconsidered, to ensure that financial statements are professionally } \\
\text { prepared and audited. }\end{array}$ \\
\hline
\end{tabular}




\begin{tabular}{|c|c|}
\hline $\begin{array}{l}\text { Principle } 15 . \text { Holders of securities in } \\
\text { a company should be treated in a fair } \\
\text { and equitable manner }\end{array}$ & $\begin{array}{l}\text { The regulatory regime adequately addresses the rights and equitable } \\
\text { treatment of shareholders, including with respect to mergers. While } \\
\text { the Law makes adequate provision for these matters, the extent to } \\
\text { which a private institutional shareholder or group of retail } \\
\text { shareholders can practically take action through the Court system } \\
\text { appears to be constrained by the cost and by the capacity of the } \\
\text { courts. Hence, the practical effect is that market discipline is } \\
\text { inadequate to enable enforcement of these rights or compliance with } \\
\text { these obligations, which places more burden to deal with cases of } \\
\text { non-compliance on the CSRC or the SROs. The reporting obligation } \\
\text { for changes in substantial shareholding (currently for changes of } 5 \\
\text { percent) should be reviewed, in keeping with the standards in other } \\
\text { major markets. }\end{array}$ \\
\hline $\begin{array}{l}\text { Principle } 16 \text {. Accounting and } \\
\text { auditing standards should be of a } \\
\text { high and internationally acceptable } \\
\text { quality }\end{array}$ & $\begin{array}{l}\text { The Chinese regulatory regime has adopted a clear set of accounting } \\
\text { and auditing standards which are well advanced in the process of } \\
\text { converging with IFRS and which are of high and internationally } \\
\text { acceptable quality. There is a need to continue to develop the size } \\
\text { and experience of the accounting and audit profession in China, } \\
\text { given the significant role that accountants and auditors play in } \\
\text { providing assurance on the accuracy and completeness of financial } \\
\text { statements of listed companies and other investment vehicles. }\end{array}$ \\
\hline $\begin{array}{l}\text { Principle } 17 . \text { The regulatory system } \\
\text { should set standards for the } \\
\text { eligibility and the regulation of those } \\
\text { who wish to market or operate a CIS }\end{array}$ & $\begin{array}{l}\text { There are clear regulatory requirements for those that wish to } \\
\text { operate or market a CIS, which provide reasonable entry } \\
\text { requirements, ongoing eligibility and conduct rules, and } \\
\text { requirements aimed at managing conflicts of interest. The } \\
\text { provisions related to the professional qualifications and experience } \\
\text { of fund managers should be reviewed as the industry develops. The } \\
\text { CSRC should be wary of the potential for unlicensed CIS activity, } \\
\text { such as Ponzi schemes, to arise in the Chinese market and give } \\
\text { attention to detecting and deterring it. The provisions relating to } \\
\text { delegations, and in particular a requirement that the fund manager, } \\
\text { custodian or securities company maintain adequate oversight of the } \\
\text { actions of delegates, should be made clearer. }\end{array}$ \\
\hline $\begin{array}{l}\text { Principle } 18 . \text { The regulatory system } \\
\text { should provide for rules governing } \\
\text { the legal form and structure of CIS } \\
\text { and the segregation and protection of } \\
\text { client assets }\end{array}$ & $\begin{array}{l}\text { The regulatory regime adequately provides rules governing the legal } \\
\text { form and structure of CIS. Segregation and protection of client } \\
\text { assets is assured through a mandatory system of third party } \\
\text { custodianship. }\end{array}$ \\
\hline $\begin{array}{l}\text { Principle 19. Regulation should } \\
\text { require disclosure, as set forth under } \\
\text { the principles for issuers, which is } \\
\text { necessary to evaluate the suitability } \\
\text { of a CIS for a particular investor and } \\
\text { the value of the investor's interest in } \\
\text { the scheme }\end{array}$ & $\begin{array}{l}\text { There are comprehensive disclosure requirements for CIS which } \\
\text { provide the information necessary to enable a prospective investor } \\
\text { to evaluate the suitability and prospects of the scheme. There are } \\
\text { adequate provisions governing valuation requirements to enable an } \\
\text { investor to determine the value of their investment. Given the high } \\
\text { level of retail participation in the market, it is very important that all } \\
\text { information should be provided in clear and simple language, and } \\
\text { the CSRC will need to monitor this closely. }\end{array}$ \\
\hline $\begin{array}{l}\text { Principle 20. Regulation should } \\
\text { ensure that there is a proper and } \\
\text { disclosed basis for assets valuation } \\
\text { and the pricing and the redemption of }\end{array}$ & $\begin{array}{l}\text { There are detailed regulatory requirements governing the valuation } \\
\text { of CIS assets including audit requirements. There are also specific } \\
\text { requirements concerning the pricing of subscription to or }\end{array}$ \\
\hline
\end{tabular}




\begin{tabular}{|c|c|}
\hline units in a CIS & redemptions from funds. \\
\hline $\begin{array}{l}\text { Principle } 21 . \text { Regulation should } \\
\text { provide for minimum entry standards } \\
\text { for market intermediaries }\end{array}$ & $\begin{array}{l}\text { The Chinese regulatory regime requires that market intermediaries } \\
\text { must be licensed with the CSRC, and are subject to initial and } \\
\text { ongoing capital and experience and qualifications requirements. The } \\
\text { CSRC should consider amending its rules on securities and futures } \\
\text { investment consultants to require such consultants to disclose in } \\
\text { detail to clients their personal backgrounds and career records, } \\
\text { working experience, compliance record, investment strategies and } \\
\text { fee structure, as the development of an independent financial } \\
\text { advising capacity can be an important part of markets with } \\
\text { significant levels of retail participation. }\end{array}$ \\
\hline $\begin{array}{l}\text { Principle } 22 \text {. There should be initial } \\
\text { and ongoing capital and other } \\
\text { prudential requirements for market } \\
\text { intermediaries that reflect the risks } \\
\text { that the intermediaries undertake }\end{array}$ & $\begin{array}{l}\text { The regulatory regime in China provides appropriate prudential } \\
\text { controls with respect to market intermediaries and that relate to the } \\
\text { risks involved in the particular businesses that market intermediaries } \\
\text { undertake. The initial registered capital requirements and the } \\
\text { ongoing risk-based net capital requirements provide a significant } \\
\text { level of prudential buffer in respect of risks. As the system of risk- } \\
\text { based net capital is relatively new, the CSRC should continue to } \\
\text { monitor it carefully to ensure that it captures all relevant risks. }\end{array}$ \\
\hline $\begin{array}{l}\text { Principle } 23 \text {. Market intermediaries } \\
\text { should be required to comply with } \\
\text { standards for internal organization } \\
\text { and operational conduct that aim to } \\
\text { protect the interests of clients, ensure } \\
\text { proper management of risk, and } \\
\text { under which management of the } \\
\text { intermediary accepts primary } \\
\text { responsibility for these matters }\end{array}$ & $\begin{array}{l}\text { The regulatory regime requires market intermediaries to have an } \\
\text { internal risk management function and controls to protect the } \\
\text { interests of clients. The concept of suitability included in the } \\
\text { requirements for trading in stock index futures should be more } \\
\text { generally applied to trading in both futures and securities, given the } \\
\text { need for retail investors to be provided with sufficient information } \\
\text { about products and services to be able to make an informed } \\
\text { investment decision. The recently introduced "Know-your-client" } \\
\text { regulations for securities companies should be carefully monitored } \\
\text { to ensure that they are resulting in investors making better informed } \\
\text { investment decisions, given the growth of the market and the level } \\
\text { of retail participation in it. In light of the apparent effectiveness of } \\
\text { the third party custodian requirements for securities firms and fund } \\
\text { management companies in preventing problems of misappropriation } \\
\text { of client assets, the CSRC should consider whether some form of } \\
\text { third party custodianship should apply to the management of client } \\
\text { margins currently held by futures companies. }\end{array}$ \\
\hline $\begin{array}{l}\text { Principle } 24 \text {. There should be a } \\
\text { procedure for dealing with the failure } \\
\text { of a market intermediary in order to } \\
\text { minimize damage and loss to } \\
\text { investors and to contain systemic risk }\end{array}$ & $\begin{array}{l}\text { The Chinese regulatory regime makes adequate provision for } \\
\text { dealing with the failure of an intermediary, building on experience } \\
\text { with significant failures of securities companies in the early part of } \\
\text { this decade. However, the authorities should consider altering the } \\
\text { threshold in the relevant regulations, that the failure "severely } \\
\text { threaten the order" of the market, to ensure that the CSRC can act } \\
\text { promptly before the problem becomes too large. }\end{array}$ \\
\hline $\begin{array}{l}\text { Principle } 25 \text {. The establishment of } \\
\text { trading systems including securities } \\
\text { exchanges should be subject to } \\
\text { regulatory authorization and } \\
\text { oversight }\end{array}$ & $\begin{array}{l}\text { The Chinese regulatory regime makes adequate provision for } \\
\text { authorization and oversight of entities which wish to operate a stock } \\
\text { or futures exchange, covering the exchanges themselves, admission } \\
\text { of products to trading, trading information and execution } \\
\text { procedures. While CSRC staff maintains regular dialogue with the } \\
\text { stock exchanges especially on listed company disclosure and trading } \\
\text { issues, annual inspections like for other exchanges should also be }\end{array}$ \\
\hline
\end{tabular}




\begin{tabular}{|c|c|}
\hline & $\begin{array}{l}\text { considered. The CSRC should also consider providing more } \\
\text { autonomy to the stock exchanges in choosing its chief executive. }\end{array}$ \\
\hline $\begin{array}{l}\text { Principle } 26 . \text { There should be } \\
\text { ongoing regulatory supervision of } \\
\text { exchanges and trading systems, } \\
\text { which should aim to ensure that the } \\
\text { integrity of trading is maintained } \\
\text { through fair and equitable rules that } \\
\text { strike an appropriate balance } \\
\text { between the demands of different } \\
\text { market participants }\end{array}$ & $\begin{array}{l}\text { The CSRC and exchanges have implemented systems for the } \\
\text { ongoing surveillance and supervision of trading, to ensure market } \\
\text { integrity. Membership and trading rules of the exchanges are subject } \\
\text { to approval by the CSRC. }\end{array}$ \\
\hline $\begin{array}{l}\text { Principle 27. Regulation should } \\
\text { promote transparency of trading }\end{array}$ & $\begin{array}{l}\text { The regulations require the provision of pre- and post-trade } \\
\text { information to market participants on a timely basis, including } \\
\text { requirements to provide such information to all participants on an } \\
\text { equitable basis. }\end{array}$ \\
\hline $\begin{array}{l}\text { Principle 28. Regulation should be } \\
\text { designed to detect and deter } \\
\text { manipulation and other unfair trading } \\
\text { practices }\end{array}$ & $\begin{array}{l}\text { The CSRC and exchanges have devoted considerable human and } \\
\text { technological resources to detecting and deterring insider trading } \\
\text { and market manipulation. At the same time, given the size of the } \\
\text { market, its rapid growth, and the enormous interest generated by } \\
\text { new listings, the number of abnormal trades detected and on which } \\
\text { action is taken seems low. The CSRC should consider some extra } \\
\text { and continuing efforts to detect and deter unfair trading practices. }\end{array}$ \\
\hline $\begin{array}{l}\text { Principle 29. Regulation should aim } \\
\text { to ensure the proper management of } \\
\text { large exposures, default risk and } \\
\text { market disruption }\end{array}$ & $\begin{array}{l}\text { The regulatory regime provides for market authorities to monitor the } \\
\text { risk of large and open positions that pose a risk to the market or } \\
\text { clearing. In the event of default, there are procedures in place to } \\
\text { ensure that the problem is isolated and does not affect other market } \\
\text { participants, and for apportioning any loss appropriately. }\end{array}$ \\
\hline $\begin{array}{l}\text { Principle } 30 \text {. Systems for clearing } \\
\text { and settlement of securities } \\
\text { transactions should be subject to } \\
\text { regulatory oversight, and designed to } \\
\text { ensure that they are fair, effective } \\
\text { and efficient and that they reduce } \\
\text { systemic risk }\end{array}$ & $\begin{array}{l}\text { Not assessed. Please refer to the separate CPSS/IOSCO assessment } \\
\text { of payment, clearing and settlement systems. }\end{array}$ \\
\hline
\end{tabular}




\section{E. Key Recommendations}

\section{The assessment team found several improvement opportunities, summarized in the Table below:}

\section{Table 19. China: Recommended Action Plan to Improve Implementation of the IOSCO Principles}

\begin{tabular}{|c|c|}
\hline Principle & Recommended Action \\
\hline Principle 1 & $\begin{array}{l}\text { Where banks or insurance companies engage in securities type } \\
\text { activities, such as establishing and distributing wealth management } \\
\text { products, they should be regulated in the same manner as wealth } \\
\text { management products regulated by the CSRC, to avoid regulatory } \\
\text { arbitrage. A review of the requirements applying to wealth } \\
\text { management products across banking, insurance and securities should } \\
\text { be conducted to ensure consistent approaches and to avoid gaps or } \\
\text { unjustified differential treatment. }\end{array}$ \\
\hline Principles 2 and 3 & $\begin{array}{l}\text { The operational budget of the CSRC should be adjusted according to } \\
\text { the size of the regulated population, and some freedom should be } \\
\text { provided to allow the CSRC to structure itself and pay salaries which } \\
\text { enable it to retain staff with appropriate qualifications and industry } \\
\text { experience. The provisions concerning the potential liability of staff } \\
\text { should be clarified to ensure that staff does not bear liability for the } \\
\text { bona fide discharge of their functions and duties. }\end{array}$ \\
\hline Principle 4 & $\begin{array}{l}\text { The CSRC, SIPF, and SROs should increase their efforts to educate } \\
\text { investors about the market and risk. }\end{array}$ \\
\hline Principle 7 & $\begin{array}{l}\text { Given the growth of the Chinese capital markets and in particular in } \\
\text { listed companies and regulated entities, the SROs will need to give } \\
\text { continued attention and resources to their regulatory functions. The } \\
\text { CSRC should consider instituting a formal program whereby it } \\
\text { conducts regular comprehensive on-site inspections of the exchanges. }\end{array}$ \\
\hline Principle 9 & $\begin{array}{l}\text { It would be useful and provide greater legal certainty to the CSRC in } \\
\text { its enforcement role if the threshold for exercise of its formal statutory } \\
\text { investigation powers were amended to provide greater discretion on } \\
\text { when it may bring those powers to bear. }\end{array}$ \\
\hline Principle 10 & $\begin{array}{l}\text { The CSRC should consider means of encouraging investors who have } \\
\text { a problem to raise their concerns with the CSRC, both to bolster the } \\
\text { market intelligence available from this source and to boost investor } \\
\text { confidence in the regulatory framework. In addition the CSRC needs } \\
\text { to devote continued attention and resources to enforcing the laws with } \\
\text { respect to illegal investment activity (including Ponzi schemes and } \\
\text { bucket shops). }\end{array}$ \\
\hline
\end{tabular}




\begin{tabular}{|c|c|}
\hline Principle & Recommended Action \\
\hline Principle 12 & $\begin{array}{l}\text { The CSRC and other domestic regulators should give more } \\
\text { consideration to the efficacy of their cooperative arrangements, } \\
\text { especially with respect to ensuring that products or activities that have } \\
\text { a similar function are regulated similarly to avoid the potential for } \\
\text { regulatory arbitrage. }\end{array}$ \\
\hline Principle 14 & $\begin{array}{l}\text { The CSRC should consider promulgating a clearer prohibition on } \\
\text { advertising unless it refers potential investors to the prospectus. The } \\
\text { level of fines for the provision of false or misleading financial } \\
\text { statements should be reconsidered. The statutory timeframes for the } \\
\text { provision of annual and semi-annual reports by listed companies } \\
\text { should be reviewed. }\end{array}$ \\
\hline Principle 15 & $\begin{array}{l}\text { The obligation to report changes in substantial shareholdings } \\
\text { (currently only for changes of over } 5 \text { percent) should be reviewed, in } \\
\text { keeping with the standards in other major markets. }\end{array}$ \\
\hline Principle 16 & $\begin{array}{l}\text { Continued attention should be given to the development of the private } \\
\text { accounting and audit profession in China, to ensure that financial } \\
\text { statement are professionally prepared and audited. }\end{array}$ \\
\hline Principle 17 & $\begin{array}{l}\text { The provisions related to the professional qualifications and } \\
\text { experience of fund managers should be reviewed as the industry } \\
\text { develops. The CSRC should be wary of the potential for unlicensed } \\
\text { CIS activity, such as Ponzi schemes, to arise in the Chinese market } \\
\text { and give attention to detecting and deterring it. The provisions relating } \\
\text { to delegations, and in particular that the fund manager, custodian or } \\
\text { securities company maintain adequate oversight of the performance of } \\
\text { a delegate, should be made clearer. }\end{array}$ \\
\hline Principle 21 & $\begin{array}{l}\text { The CSRC should consider amending its rules on investment } \\
\text { consultants to require such consultants to disclose in detail to clients } \\
\text { their personal backgrounds and career records, working experience, } \\
\text { compliance record, investment strategies and fee structure, as the } \\
\text { development of an independent financial advising capacity can be an } \\
\text { important part of markets with significant levels of retail participation. }\end{array}$ \\
\hline Principle 22 & $\begin{array}{l}\text { As the system of risk-based net capital is relatively new, the CSRC } \\
\text { should continue to monitor it carefully to ensure that it captures all } \\
\text { relevant risks. }\end{array}$ \\
\hline
\end{tabular}




\begin{tabular}{|c|c|}
\hline Principle & Recommended Action \\
\hline Principle 23 & $\begin{array}{l}\text { The concept of suitability included in the requirements for trading in } \\
\text { stock index futures should be more generally applied to trading in both } \\
\text { futures and securities, given the need for retail investors to be } \\
\text { provided sufficient information about products and services to be able } \\
\text { to make an informed investment decision. In light of the apparent } \\
\text { effectiveness of the third party custodian requirements for securities } \\
\text { firms and fund management companies in preventing problems of } \\
\text { misappropriation of client assets, the CSRC should consider whether } \\
\text { some form of third party custodianship should apply to the } \\
\text { management of client margins currently held by futures companies. } \\
\text { The recently introduced "Know-your-client" regulations for securities } \\
\text { companies should be carefully monitored to ensure that they are } \\
\text { resulting in investors making better informed investment decisions, } \\
\text { given the growth of the market and the level of retail participation. }\end{array}$ \\
\hline Principle 24 & $\begin{array}{l}\text { The authorities should consider altering the threshold in the relevant } \\
\text { regulations for intervention in the failure of a market intermediary, } \\
\text { that the failure "severely threaten the order" of the market, to ensure } \\
\text { that the CSRC can act promptly before the problem becomes too large. }\end{array}$ \\
\hline Principle 25 & $\begin{array}{l}\text { Annual inspections of the stock exchanges should be instituted, as } \\
\text { they are for futures exchanges. The CSRC should consider providing } \\
\text { more autonomy to the stock exchanges in choosing its chief executive. }\end{array}$ \\
\hline Principle 28 & $\begin{array}{l}\text { The CSRC should consider some extra and continuing efforts to detect } \\
\text { and deter unfair trading practices, including: } \\
\text { - Educating company officers, officers of securities and futures } \\
\text { companies and related parties that insider trading and other } \\
\text { market manipulation is a criminal offence; } \\
\text { - Educating prosecutors and judges about the impact that insider } \\
\text { trading has on investor confidence in the market; } \\
\text { Redoubling efforts at investigating suspicious trading around } \\
\text { events likely to involve it, like initial public offerings (IPOs) and } \\
\text { merger announcements, and lowering the thresholds for } \\
\text { investigating or making enquiries; } \\
\text { Considering whether special rules should be developed to } \\
\text { suspend or quarantine the proceeds of suspicious trades, including } \\
\text { considering lowering the threshold of the level of suspicion (for } \\
\text { freezing or quarantining actions) or altering the definition of } \\
\text { abusive or suspicious trades to facilitate taking civil or } \\
\text { disciplinary action; and } \\
\text { Considering measures related to product design, especially in } \\
\text { relation to futures products, to make them sufficiently broad- } \\
\text { based that it is difficult for insider trading or market manipulation } \\
\text { to be successful. }\end{array}$ \\
\hline
\end{tabular}




\section{F. Authorities' Response}

172. CSRC appreciates the immense time, efforts and resources devoted by the FSAP Assessors, the World Bank and the International Monetary Fund, to the FSAP assessment, and to the compiling of the Report of Observance of Standards and Codes: IOSCO Assessment of Securities Markets (hereinafter: the Report). The Report has, in a general sense, managed to reflect the implementation of the IOSCO objectives and principles by China's securities and futures regulatory system. We fully understand how challenging and complex it was to conduct such a project as to review China's capital market, the world's largest emerging market in transition. Therefore, we marvel at and are moved by how much the Assessors managed to accomplish in relatively limited amount of time. They held scores of meetings with the CSRC headquarters and regional offices. They met with various regulated entities, SROs, service providers and local governmental officials. They also went through colossal volumes of reading materials. The Assessors have not only conducted comprehensive reviews of China's capital market and its regulation, but also put forward many valuable comments and recommendations.

173. We are grateful for the opportunity to make a formal response to the Report. We identify with most of the Report, including its major Findings and part of the Recommendations. To start with, the Report highly recognizes the development and achievements of China's capital market over the past two decades, as well as the regulatory efforts thereof, noting "Reforms in recent years, in particular the nontradable shares reforms, the introduction of stock index futures trading in 2010, and the overhaul of third party custodian and risk-based net capital requirements for securities firms, have enhanced the transparency of the market, broadened the range of available products and improved the financial soundness of intermediaries, to the considerable benefit of investor protection in China. These reforms have been carefully planned and implemented, and have been welcomed by market participants. They provide evidence of an active and strategic approach to regulation of the Chinese securities markets on the part of the CSRC and other authorities." Meantime, the Report also points out that these reforms have built on an extensive set of regulatory provisions which have drawn on the experience of other more developed securities markets, and that there are few areas in which the regulatory framework does not meet the IOSCO standards. In addition, the Report acknowledges that "the Chinese regulatory regime has adopted a clear set of accounting and auditing standards which are well advanced in the process of converging with the IFRS and IAS and which are of high and internationally accepted quality."

174. After reading the Recommendations of the Report, we recognize that all of them are worthy of immense attention and some of the Recommendations have already been incorporated into our work plans. For example:

\section{a. Regarding the regulator}

175. With lessons drawn from the latest financial crisis, we identify with relevant 
Recommendations in the Report, such as strengthening regulatory coordination among different Regulators (i.e., the CSRC, the CBRC, and the CIRC), placing unregulated markets and products under regulation, allowing greater flexibility for the Regulator in terms of staffing and budget, clarifying relevant provisions to ensure that regulatory staff do not bear liability for the bona fide discharge of their functions and duties, etc. In response to these Recommendations, China's regulatory authorities will take further measures to enhance the efficacy of the CBRC-CSRC-CIRC MOU to avoid potential regulatory gap. Meantime, China's regulatory authorities are taking active measures that will cover the previously unregulated institutions and products (e.g., private equity funds). With regard to Recommendations to increase regulatory resources and to exempt staff from liability for the bona fide discharge of duties, the CSRC will further consult with relevant government agencies, as well as legislative and judicial authorities. We believe more regulatory resources that are proportionate to China's political system, economic status and the overall income level of its financial industry will manage to satisfy the regulatory demand of an everexpanding market.

\section{b. $\quad$ Regarding SROs}

176. We agree with the Report that the SROs will need to give continued attention and resources to their regulatory functions; and that the CSRC, SIPF, and SROs should increase their efforts to educate investors about the market and risk. We recognize that given the rapid growth of the Chinese capital market and in particular in listed companies and regulated entities, the functions of SROs need to be further tapped into. The CSRC will enhance its regulation of and communication with the SROs, and will seriously consider relevant Recommendation to conduct regular comprehensive onsite inspections of the stock exchanges.

177. However, we cannot agree with some Findings and Recommended Actions in the Report, which we think are misunderstandings and erroneous. We feel that such misunderstandings and errors are partly due to the lack of sufficient understanding of China's capital market, its features and mechanisms; and partly due to the failure to acknowledge the remedies that have already been put in place, or perhaps to the lack of trust in the efficacy of existing mechanisms and measures. In some cases, the Report even denies, without sufficient proof that such regulatory practices are ineffective, some tried-and-trusted practices that are unique to the Chinese market. We would like to express our concerns.

\section{c. Regarding enforcement}

178. We do not think the Report has sufficiently reflected CSRC's efforts and achievements in cracking down on illegal investment and insider-trading. In 2006, the Steering Group on Cracking Down upon Illegal Securities Activities was jointly established by the CSRC and Ministry of Public Security. With the aim to organize and coordinate domestic efforts in combating illegal securities activities, the work of this Steering Group has yielded visible results. In our daily work, the CSRC monitors various public news media 
including the internet, in order to timely detect clues of securities violations for prompt handling. In 2001, the CSRC enacted the Notice on Implementing an Incentive Mechanism for the Reporting of Illegal and Fraudulent Securities and Futures Trading, encouraging investors to blow whistles on illegal securities and futures activities. Pursuant to China's securities laws, any securities or futures violation that exceeds RMB 300 thousand constitutes a crime, and shall be referred by the CSRC to public security authorities. To sum up, illegal investment activities akin to Ponzi schemes and boiler rooms have been effectively detected and punished.

\section{d. Regarding intermediaries}

179. The Report recommends that there should be initial and ongoing capital and other prudential requirements for market intermediaries that reflect the risks that the intermediaries undertake. The Report also recommends that "as the system of risk based net capital is relatively new, the CSRC should continue to monitor it carefully to ensure that it captures all relevant risks." However, we believe that CSRC's supervision of net capital is sufficient and appropriate. The risk-based net capital system, featured by off-site supervision and on-site inspection, and timely and effective regulatory measures taken against problematic intermediaries, has proved to capture risks very well. Moreover, ever since 2007, the CSRC has been continuously monitoring and assessing the net-capital based risk regulatory system via IT monitoring platforms, and requires regular stress-test thereof.

180. In recent years, the CSRC has made a series of improvement on market infrastructure, and the futures market has achieved a great progress. The monitoring system of the secured custody of futures margins has taken into full consideration of the characteristics of futures trading, and the status quo of the market. It has played a significant and indispensable role in securing a healthy and stable development of the futures market. We wish to share the experience of our innovative regulatory system with regulators from other countries, and to enhance financial regulation through strengthening communication.

\section{e. Regarding accounting and auditing standards}

181. We regret to say that we cannot identify with the Rating result of IOSCO Principle 16. In order to ensure high quality auditing for listed companies and other market players, the CSRC has established a qualification license system, allowing only accounting firms that have obtained the qualification license to perform auditing for listed companies and other market players. The CSRC conducts all-round regulation including onsite inspection to the accounting firms with relevant qualifications (currently 53 firms), listed companies and other major market players. Judging from the reality, the size and professional capability of accountants and auditors are enough to satisfy the needs of the capital market.

\section{f. Conclusion}

182. While we may not agree with everything the Report says, we fully agree with what the Assessors kindly reminded during one of our numerous meetings - that we should not 
take pride in the findings, nor rest on our past laurels. In this sense, the FSAP Assessment stands as a good chance for us to retrospect the past and take a prudent look into the future. After all, given the tremendous changes that the world is undergoing, China's capital market is exposed to profound changes and challenges, both home and abroad, while its regulators are encountered with an increasingly complex market and ever-growing tasks of maintaining sound and steady growth. An incomplete list of the challenges that we are facing include issues such as how to further build and improve the market legal framework, enhance enforcement and deterrence, so as to better protect the lawful rights of investors; how to strengthen regulatory coordination and function-based regulation with regard to various wealth management products offered to the public, so as to minimize potential regulatory gaps; how to regulate the once unregulated markets and products, striking appropriate balance between financial innovation and regulation; how to prevent and resolve systemic risks, strengthen the oversight of cross-border capital flow and sound early warnings of risks from abroad; how to cultivate sophisticated investors and encourage institutional investors, etc. We recognize that they are but some of the challenges we are faced with, that call for our unremitting effort and commitment. As regulators of China's capital market, we have a long and promising way ahead of us. 


\section{ANNEX IV: OBSERVANCE OF FinanCial SECTOR STANDaRdS ANd CODES-ASSESSMENT of ObServance of CPPS Core Principles for Systemically IMPortant Payment SYSTEMS: A SUMMARY}

\section{A. Introduction}

183. The assessment was conducted in June 2010. In addition to the 2001 CPSS-CPSIPS Report, the methodology used follows the Guidance Note for Assessing Observance of CPSIPS prepared by the IMF and the World Bank in collaboration with the Committee for Payment and Settlement System (CPSS) in August 2001.

184. The information used included all relevant laws, rules and procedures governing the systems, the abundant material available on the issue inside and outside the central bank. ${ }^{11}$ In addition, extensive discussions were held with regulators-PBC, MOF, CSRC, CBRC, and SAFE; several stakeholders in the Chinese Payments System, including the big four commercial banks, joint stock commercial banks, city commercial banks, policy banks, foreign banks, and rural banks, ${ }^{12}$ funds management companies, the card operator (China Union Pay), the China Foreign Exchange Trade Center (CFETC) and securities depositories - China Central Depository \& Clearing Co., Ltd. (CCDC) and China Securities and Clearing Corporation Limited (SD\&C). A self assessment by the PBC of the country's SIPS with the CPSS Core Principles as well as of the central bank's responsibilities in applying the Core Principles (CPs) was provided prior to the mission. The self-assessment was prepared by the PBC Payment and Settlement Department, in close consultation with the major stakeholders of the China National Payments System (CNPS).

\section{B. Institutional and Market Structure}

185. In recent years, the $\mathrm{PBC}$ has carried out a major and comprehensive reform of the CNPS. The PBC implemented the CNAPS, which consists of the HVPS and the Bulk Electronic Payment System (BEPS). The HVPS system currently operates in a tiered way (multi-entry point) with a national processing center (NPC) and 32 local processing centers (LCPs). The HVPS system is interconnected to many trading, payments, and securities settlement systems (SSS) to allow for central bank money settlement. In addition, there are

\footnotetext{
${ }^{11}$ The China Payment System Development Reports, 2007, 2008, and 2009, prepared by the PBC Payment and Settlement Department were particularly relevant.

${ }^{12}$ Bank of China (BoC), Industrial Commercial Bank of China (ICBC), China Construction Bank (CCB), Agricultural Bank of China (ABC), Bank of Beijing (BOB), China Development Bank (CDB), Bank of Communication, Shanghai Pudong Development Bank, Standard Chartered Bank, HSBC, Bank of East Asia (BOEA), JP Morgan-Chase, and Shandong United Rural Cooperative.
} 
numerous cheque clearing houses around the country administered by the PBC local offices or delegated to banks. China Union Pay (CUP) handles the clearance of cards transactions whose balances are settled in the HVPS. Also automated clearinghouses (ACHs) and other systems handle clearance and settlement for a variety of payment instruments.

186. The HVPS is a systemically important payment system, as it is the backbone of the national payments system in China. The HVPS handled transactions for a value of CY 804 trillion in 2009, approximately 24 times the GDP value. Thus, the HVPS is being assessed against the ten CPSIPS of the CPSS and the four responsibilities of the central banks in applying the CPSIPS. The BEPS is not currently a systemically important payment system. However, its importance for an efficient settlement of the interbank payment system is growing.

187. The cheque clearinghouses around the country also handle an important value of transactions. The gross value of cheques issued in 2009 reached a value of CY 248 trillion in 2009, about 7.4 times the GDP. However, of this amount, 350 million cheques are interbank cheques valued at about CY 62.5 trillion. This means that the majority of the cheques issued in the country are "on us" cheques. Also, ACHs handled CY 69 trillion in 2009, about two times the GDP, relatively important (though not major) for a big country like China. Thus, neither the cheque clearinghouses nor the ACHs have been considered systemically important in this assessment but their relative importance has been taken into consideration in the assessment of Responsibility B and C.

188. Regarding the use of payment instruments, China is evolving to a more intensive use of non-cash payment instruments, especially cards. The relationship of cash (M0) to GDP has been declining since the beginning of the 2000 from a level of 14.8 percent of GDP in 2000 to 11.2 percent in 2009. Bank cards issuance have been increasing at a high pace and approximately 2.07 billion had been issued at end-2009, of which 1.88 billion were debit cards. Bank cards have therefore become the primary non-cash payment instrument in China accounting for over 90 percent on the total non-cash volume in 2009.

189. Domestic foreign exchange (FX) transactions are mostly executed at the CFETC. The majority of participants settle their transactions bilaterally while 26 participants use a net clearing model and the CFETC acts as CCP at end-2010. Settlement of the CY leg occurs through the HVPS and settlement of the foreign currency leg with domestic settlement banks, at which participants hold FX accounts. The mission was not provided with complete data of the transactions cleared and settled through the multilateral arrangement nor has the PBC conducted an assessment of this payment system. However, in light of the nature of these transactions and the potential systemic importance of the system, the PBC is urged to assess the compliance of this system with international standards as soon as possible. 
190. The China Domestic Foreign Currency Payment System (FCPS) was launched in April 2008 to handle the clearing and settlement of domestic foreign currency denominated transactions. The FCPS is a Real-Time Gross Settlement (RTGS) system and currently handles payment transactions in seven foreign currencies. The values settled in the system do not show a systemic importance of the system.

\section{Payment Systems Oversight}

191. PBC powers to oversee payment and settlement systems have a sound and clear legal basis, CSRC has overlapping oversight powers on the securities settlements. PBC oversight and regulatory powers over retail payments, interbank payments, securities settlements and related functions are recognized in the legal framework. These powers are articulated in the Article 4 of the "Peoples Bank of China law." The securities commission also has oversight powers over securities settlements, including government securities, derived from Article 179 of the "Securities law." A formal memorandum of understanding $(\mathrm{MoU})$ defines general cooperation arrangements among the $\mathrm{PBC}, \mathrm{MOF}$ and other authorities, such as the CSRC and the CBRC. There is no specific MoU defining the modus operandi of these authorities over payment and settlement systems, however, there have been frequent coordinated actions and regular meetings at the technical level.

192. The PBC carries out its oversight function over all payment arrangements in the country. In addition to overseeing the systemically important payment systems in the country, the PBC has played a catalyst role in reforming interbank payment arrangements in China. Recently, PBC oversight has been extended to nonbank payment service providers. However, the PBC has not issued a comprehensive document covering the objectives, scope, instruments and institutional arrangements of its oversight function as yet.

193. The PBC has implemented a data analysis platform to assist in its oversight activities. The Payment Management Information System (PMIS) gathers payment and settlement information from various systems including HVPS and BEPS. This system provides various standard analytical reports and various ad-hoc analysis features which assist $\mathrm{PBC}$ in its oversight activities. PMIS also enabled the PBC to monitor the liquidity position of the participants in real-time.

194. The PBC has not yet formally established any national payments council. The central bank has legal authority to establish a self-regulated China payments and clearing association, but it has not yet established one, although it is working on a project to create the China National Payment and Clearing Association.

195. The PBC, in cooperation with other authorities and relevant stakeholders, is working on a number of projects to further improve the safety and efficiency of the CNPS. They include: the launch of a "second generation" version of the CNAPS; a reform of 
key aspects of the legal and regulatory framework; and initiatives to further increase the penetration of retail payment services, in particular in rural areas and through the use of innovative channels and modalities.

\section{Main Findings}

196. The assessment team found the payment systems in China to be operated in a safe way. However, several improvement opportunities, summarized in Table below, were identified.

Table 20. China: Recommended Actions to Improve Observance of CPSS Core Principles and Central Bank Responsibilities in Applying the CPs

\begin{tabular}{|l|l|}
\hline \multicolumn{1}{|c|}{ Reference Principle } & \multicolumn{1}{c|}{ Recommended Actions } \\
\hline Legal foundation 1 & $\begin{array}{l}\text { Chinese authorities should accelerate the legislative process to } \\
\text { complete the reform of the legal and regulatory framework for } \\
\text { payment and securities settlement. This will include: }\end{array}$ \\
$\begin{array}{ll}\text { The enactment of a payment system law to give full legal } \\
\text { protection, among other things, to settlement finality and } \\
\text { netting arrangements. }\end{array}$ \\
$\begin{array}{l}\text { The introduction of the Interpretation of Enterprise } \\
\text { Bankruptcy Law or revision of the Enterprise Bankruptcy } \\
\text { Law to exempt the payment system sector from the "zero- } \\
\text { hour rule." } \\
\text { Understanding and management of risks } \\
\text { Ths } 2 \text { and } 3 \\
\text { The upgrade of payment system rules and procedures to the } \\
\text { level of PBC regulation. }\end{array}$ \\
$\begin{array}{l}\text { As it is not clear whether participants are fully aware of the } \\
\text { potential legal risk associated with settlement finality, the PBC } \\
\text { might want to inform participants about the measures it took to } \\
\text { mitigate this risk and the projects under way to eliminate it. } \\
\text { The PBC should further monitor the credit risk and liquidity risk } \\
\text { of the system by improving relevant rules and building the } \\
\text { second-generation payment system. Relevant actions mainly } \\
\text { include: } \\
-\quad \begin{array}{l}\text { Provide participants with more comprehensive queuing and } \\
\text { account monitoring functions, "package" liquidity real-time } \\
\text { inquiry functions and large-value payment system queuing } \\
\text { matching. }\end{array}\end{array}$ \\
\hline
\end{tabular}




\begin{tabular}{|c|c|}
\hline & $\begin{array}{l}\text { Apply more active mark-to-market mechanisms for the } \\
\text { collateral used in the intra-day liquidity facility. } \\
\text { As liquidity conditions evolve, maintain flexibility in the } \\
\text { conditions applied to intra-day liquidity facilities and } \\
\text { consider the removal of charging for collateralized credit. }\end{array}$ \\
\hline $\begin{array}{l}\text { Settlement } \\
\text { CPs } 4,5 \text {, and } 6\end{array}$ & - \\
\hline $\begin{array}{l}\text { Security and Operational Reliability, and } \\
\text { Contingency Arrangements } \\
C P 7\end{array}$ & $\begin{array}{l}\text { The second-generation payment system will have a more efficient } \\
\text { operation and maintenance mechanism, which realizes automatic } \\
\text { upgrading of the system application software; it will: } \\
\text { - } \quad \text { improve the real-time operation monitoring function, } \\
\text { which carries out comprehensive and automatic } \\
\text { monitoring of the IT resources of the payment system; } \\
\text { - improve the risk warning capability, effectively } \\
\text { analyzing the potential risks of the system and giving } \\
\text { timely warning; } \\
\text { - realize automatic handling of system failures to the } \\
\text { maximum degree; and } \\
\text { reduce the system maintenance work load, increasing the } \\
\text { operation monitoring efficiency and upgrading the } \\
\text { operation maintenance level. } \\
\text { The second-generation payment system will build the backup } \\
\text { system with complete production recovery capability, business } \\
\text { switching capability and data searching capability on the } \\
\text { framework of the production center, remote backup center and the } \\
\text { data backup center in the same city to ensure the continuous } \\
\text { processing of payment and the security and integrity of } \\
\text { information and data in case of emergency. } \\
\text { The above measures are strongly encouraged. }\end{array}$ \\
\hline $\begin{array}{l}\text { Efficiency and Practicality of the System } \\
C P 8\end{array}$ & $\begin{array}{l}\text { Notwithstanding the important progresses achieved since the } \\
\text { launch of the CNAPS, some features might be adjusted to } \\
\text { increase efficiency and practicality to the users, such as: } \\
\text { 1) The "multiple access point" feature of the system might } \\
\text { impact the efficient management of liquidity and adds to the } \\
\text { cost of participating in it. } \\
\text { 2) High value electronic transactions might still be perceived as } \\
\text { relatively more expensive vis-à-vis large value cheque } \\
\text { transactions, although it is noted that commercial banks are } \\
\text { gradually switching their customers to other electronic } \\
\text { payment options. } \\
\text { 3) Operating hours could be extended to reflect the growing } \\
\text { importance of the system. }\end{array}$ \\
\hline $\begin{array}{l}\text { Criteria for Participation } \\
C P 9\end{array}$ & $\begin{array}{l}\text { To further strengthen supervision and management of the } \\
\text { payment system participants and guarantee the secure and stable } \\
\text { operation of the payment system, PBC plans to revise the }\end{array}$ \\
\hline
\end{tabular}




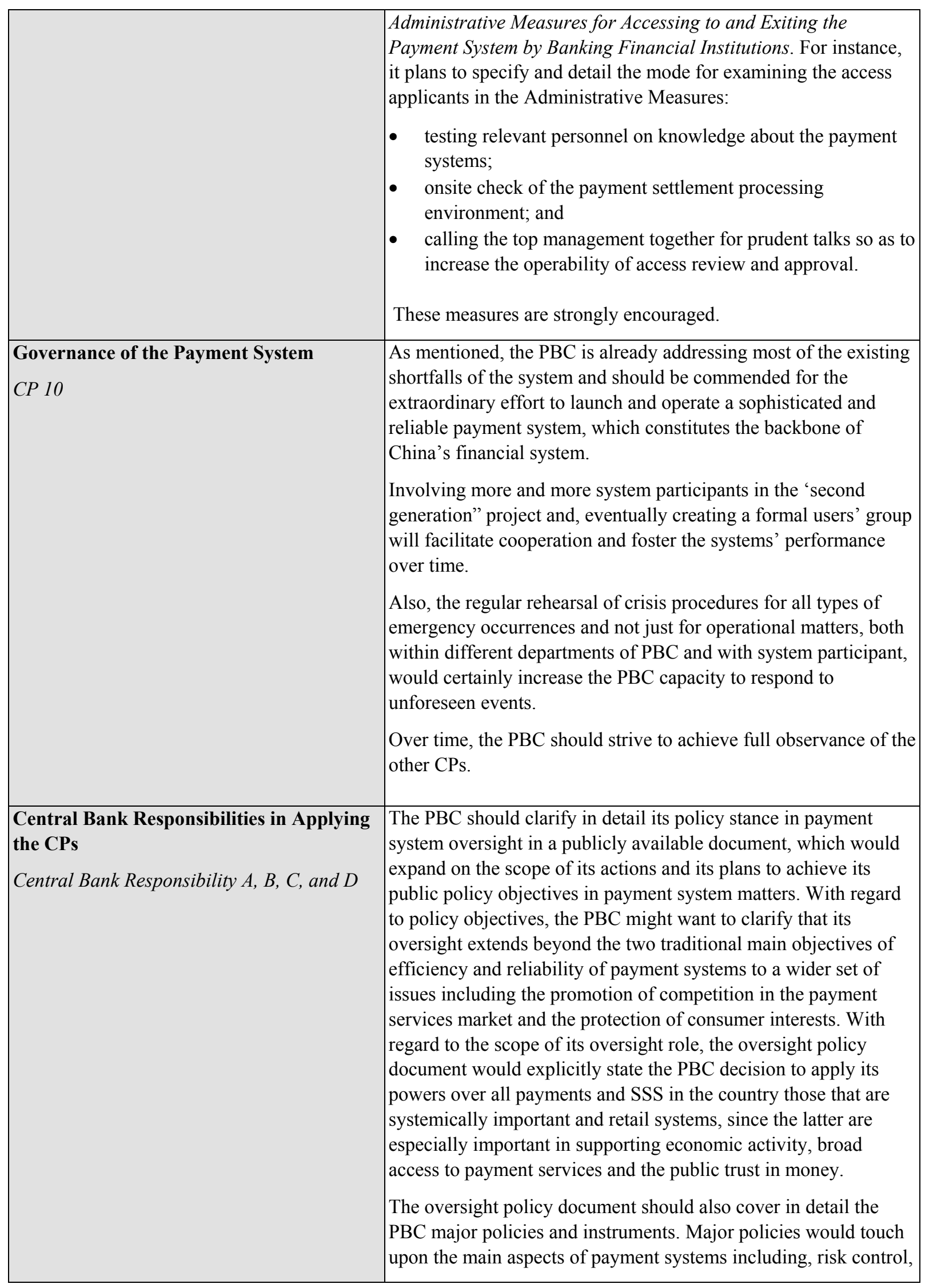




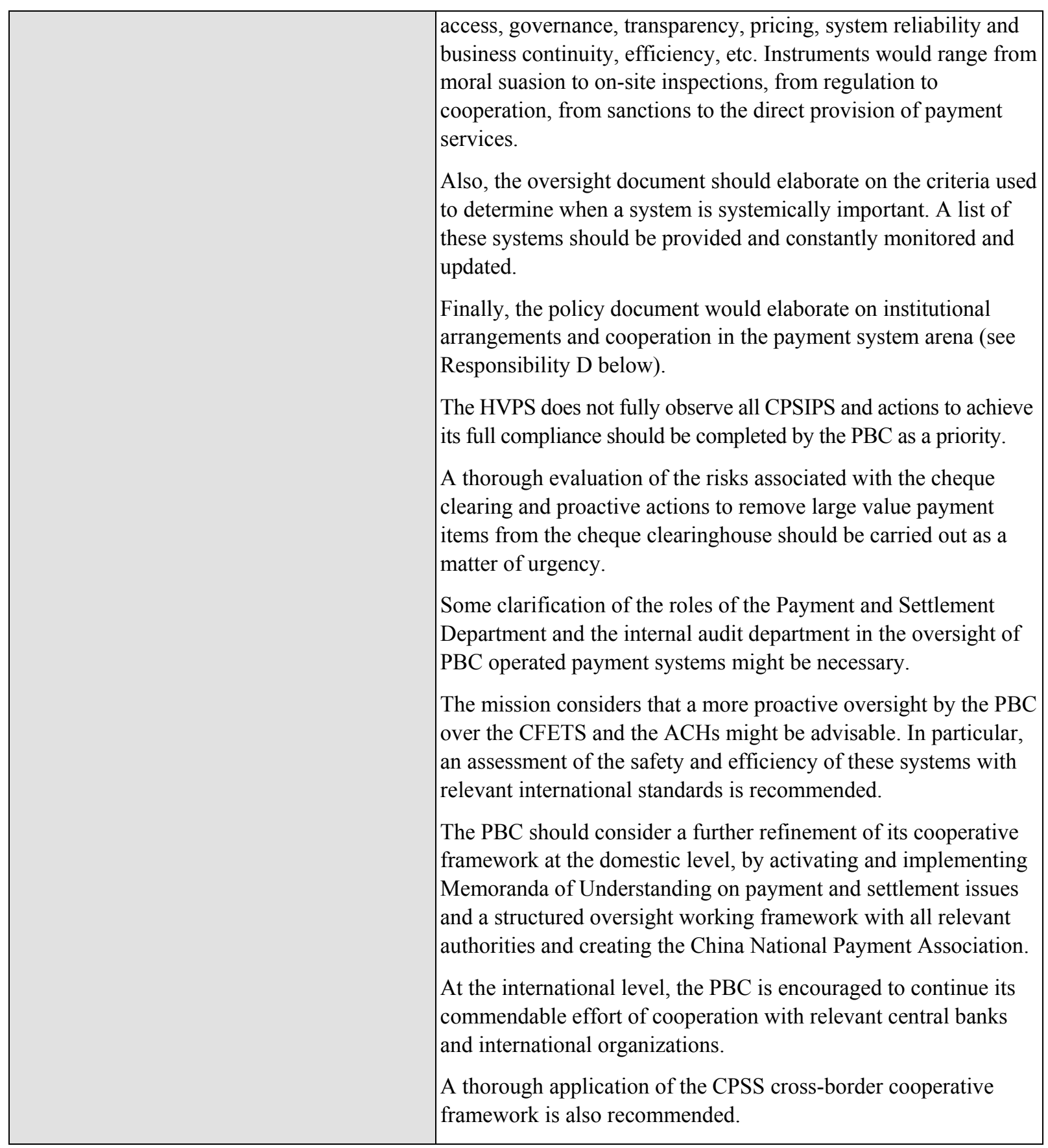

\section{E. Authorities' Response}

197. The Chinese authorities welcome and support the CPSS assessment as an opportunity for reflection and improvement for China payment and settlement system according to international standards. The assessment team has undertaken an excellent task, demonstrating high quality, professionalism, dedication and the ability to cut through complex issues in a 
constrained timeframe. The authorities appreciate the opportunity to provide the following comments.

198. Over the past decade, China has continuously pushed forward the development of China payment and settlement system, which constitute the backbone of China's financial system. We have built a payment network consisting of the central bank inter-bank payment systems, the banking institutions' internal payment system, the security settlement system, the FX settlement system, the bankcards payment system and other retail payment systems run by private sectors. Non-cash payment instruments have been widely used and met various payment requirements. Commercial drafts have been underwritten and transferred in an electronic way. Bankcards penetration ratio has been on a fast track and bankcards have been the most widely used payment instrument by Chinese residents. Online payment, mobile payment and telephone payment have been developing dramatically. The application of non-cash payment instruments has greatly facilitated economic production and civil life, reduced cash circulation and transaction costs. Payment providers have been diversified. These include the central bank, banking institutions, nonbanking institutions and securities settlement institutions as payment organizations. The payment services have been marketdriven. Modern payment means have also found their way in rural areas. The pilot crossborder trade settlement in RMB has developed in an orderly way. The management system of bank settlement accounts has improved on a gradual basis. The PBC has promulgated regulations on bank settlement accounts and established the bank settlement account management system to implement regulations. At the same time, the $\mathrm{PBC}$ launched a nationwide identity authentication system of accounts with the Police Bureau to implement the "know your customer" scheme. The payment system oversight has been strengthened, with safety and efficiency as the priority. The PBC has also improved supervision techniques and realized the DVP mode in the bond market.

199. The Large Value Payment System (LVPS) run by the PBC has been designated as the systemically important payment system and has been assessed against the CPs. The assessment concluded that the system observes (observed or broadly observed) all the CPs except CPI (legal basis). The PBC pays high attentions to the assessment results and appreciates valuable recommendations of the IMF and the WB. In implementing the recommendations, the $\mathrm{PBC}$ has realized one point entry in CNAPS1, e.g., the treasury centralized booking system and China postal savings bank's internal payment system have been connected to CNAPS1 from one point and settled their transactions with one account.

200. Measures will be taken to strengthen our legal foundation, management and supervision of China payment systems, so as to improve its practicality and efficiency in the future.

- $\quad$ CP I legal Foundation. The PBC has been aware of the shortcomings in the legal framework, and has decided to draft a payment system act to avoid the effects of the 
"zero hour rule" and give the legal recognition of netting arrangements and settlement finality. But the process of establishing legislation will take time and may involve many authorities.

- $\quad$ CP VIII Practicality and Efficiency. The PBC is launching the 2nd generation of CNAPS to increase efficiency and practicality. CNAPS2 will be designed to extend the opening hours of settlement to meet the needs of users in different areas and various financial markets.

- $\quad C P X$ Governance. The PBC has decided to improve management, upgrade the payment system and conduct a regular drill of emergency procedures, with an aim to achieving full observance of the CPs.

201. Central Bank Responsibilities $A, B, C$, and $D$. The PBC fully agrees with the recommendations and will take proper measures to ensure full observances of all CPs. The PBC will clarify in detail its policy stance in the payment system oversight in a publicly available document, and extend its oversight over all payments and securities settlement systems, including the systemically important systems and retail payment systems. The PBC will assess the safety and efficiency of the CFETS and the ACHs with relevant international standards. Besides, the PBC is about to establish the China National Payment Association and strengthen cooperation with relevant authorities, foreign central banks and international organizations. 


\section{AnNex V: ObServance of Financial Sector Standards And Codes-ASSESSMent OF OBSERVANCE OF CPPS-IOSCO RECOMMENDATIONS FOR SECURITIES SETTLEMENT SYSTEMS AND CENTRAL COUNTERPARTIES: A SUMMARY}

\section{A. Introduction}

202. This summary is based on the Recommendations of the Committee on Payment and Settlement Systems (CPSS) and the International Organization of Securities Commissions (IOSCO) for Recommendations for Securities Settlement Systems (RSSS) and the Recommendations of CPSS-IOSCO for Central Counterparties (RCCP). This assessment was conducted in September 2010.

203. The information used in the assessment included relevant laws, rules and procedures governing the systems, and other available material. ${ }^{13}$ In addition, extensive discussions were held with regulators and overseers: PBC, CSRC, SSE, SHFE, DCE, ZCE, CFFEX, CCDC, SD\&C, SAC, CFA; several stakeholders, including banks and brokerdealers active on the SSE, SHFE, and the interbank bond market, participants of the CCDC and SD\&C as well as banks that facilitate settlement and funds custody for corporate securities and futures. Three self assessments were prepared by the CCDC for the CCDC settlement system, by the SHFE for the SHFE clearing and settlement system and by the Department of Market Supervision of the CSRC for the SD\&C clearing and settlement system. Other relevant information was derived by the assessment process for Systemically Important Payment Systems (SIPS).

204. The assessment was conducted on processes and functions as opposed to institutions. Given that the bonds are mostly traded over the counter (OTC), the processes relating to trades outside the stock exchange were also examined.

\section{B. Institutional and Market Structure}

205. The Securities Settlement Systems (SSS) in the PRC are organized around three different types of markets, which are the bond market, the corporate securities market and the futures market. The bond market comprises the interbank bond market, the exchange bond market, and the bank counter market. The interbank bond market is the most dominant market, with more than 97 percent of total bond trading volume. The two stock exchanges, the SSE and the SZSE, were established in 1990 and offer trading in the same

\footnotetext{
${ }^{13}$ CSRC Annual Reports 2008 and 2009, CDC Annual Report of China's Bond Market 2009, PBC responses on the FSAP questionnaire for payment systems and securities clearing and settlement; websites from CSRC, SSE, SZSE, SHFE, CDCC/Chinabond; and other relevant documents.
} 
type of securities, being shares, bonds, funds and warrants. Turnover on both stock exchanges is relatively high and has grown tremendously during the last decade. According to the World Federation of Stock Exchanges, as of 2009, the SSE ranks as the $3^{\text {rd }}$ exchange worldwide in share trading with RMB 34 trillion, and the SZSE as the 6th with RMB 18 trillion. There are also three commodities exchanges: SHFE, DCE, and ZCE. The SHFE ranks as the 10th derivatives exchange worldwide, measured in number of contracts traded and the second largest commodity exchange. A CFFEX was established in 2006 as a joint venture of the SSE, SZSE, SHFE, DCE, and ZCE but still volume and value of transactions are relatively modest.

\section{The CCDC is the SSS as well as the central securities depository (CSD) for}

bonds. It is the only institution entrusted by the MOF to be the depository for government securities. The CCDC was established in 1996 as a Government entity and since then it is regulated by the $\mathrm{PBC}$ and overseen by the $\mathrm{PBC}$ and $\mathrm{MOF}$. In addition, the $\mathrm{CBRC}$ is in charge of the appointment of Executive Managers of CCDC. The CCDC settles bond transactions (spot, repo, forward) on a gross basis for both bonds and funds, though CCDC management under PBC guidance, is currently considering introducing also a netting facility. Securities are held at the end-investor level in most cases ( 98 percent). The CCDC book entry system is interconnected with the interbank trading system (operated by the China Foreign Exchange Trading System (CFETS)). Cash settlement takes place in the central bank HVPS. Settlement takes place on $\mathrm{T}+0$ for most transactions ( 82.9 percent of total value settled in 2009). In addition to the commonly used delivery versus payment (DvP) settlement, CCDC allows for other settlement modalities, Payment after Delivery $(\mathrm{PaD})$, Delivery after Payment (DaP) and Free of Payment (FoP).

\section{The SD\&C is the central counterparty (CCP), SSS, as well as the CSD for all} instruments traded on the SSE and SZSE. The SD\&C was established in 2001 and is jointly owned by the SSE (50 percent) and the SZSE (50 percent). Securities settlement arrangements for SSE and SZSE are based on front-end availability of securities and funds, otherwise transactions do not take place. Securities are held at the investor level detail in the SD\&C while funds are kept through a system of third party custodian banks with the SD\&C acting as the settlement agent.

208. The four futures exchanges have their own clearing and settlement departments, which offer the function of a CCP. Settlements can be either in cash (daily mark to market) as well as physical settlements (delivery on expiration). The exchanges operate a premargining system, that is, futures contracts can only be purchased under the premise of sufficient margin deposits. In addition to the pre-margining system the exchanges have established other risk management controls including: price limits, limits to speculative positions and large holders, compulsory closed-out of positions, a system of warning indicators, and settlement reserves. Cash settlement is effected through the accounts of five commercial "settlement" banks. The "settlement" banks only operate as custodians for 
margins and facilitators for transfers of funds with the futures exchanges conducting settlement functions. Also, the China Futures Margin Monitoring Center was established in 2006 as a non-profit company under the sponsorship of the three futures exchanges to guarantee the safety of futures margin.

\section{The CCDC, SD\&C, and SHFE/DCE/ZCE operate important securities and} derivatives settlement systems both, due to the large volume and value of transactions (GDP comparison) and the fact that they support key financial sector markets (interbank bond market, stock exchanges and futures). Therefore, the CCDC and SD\&C are being assessed below against the 19 RSSS and the SHFE is being assessed against the 15 RCCP. The SD\&C operates as a CCP for most of the market transactions but given the "unique" features of its settlement process (front-end control of securities and funds) it is being assessed against the RSSS. The other two commodities futures exchanges, DCE and ZCE, follow very similar settlement procedures to the SHFE, thus, findings and recommendations for the SHFE are also applicable to DCE and ZCE.

\section{Main Findings}

210. The assessment team found the securities settlement systems in China to be operated in a safe way. However, several improvement opportunities, summarized in Tables 21,22 , and 23 , were identified.

Table 21. China: Recommended Actions to Improve Observance of CPSS-IOSCO RSSS-OTC Bonds Market-CCDC

\begin{tabular}{|c|c|}
\hline Reference Recommendation & Recommended Action \\
\hline Legal risk & \\
\hline $\begin{array}{l}\text { Recommendation 1. SSS should have a well-founded, } \\
\text { clear and transparent legal basis in the relevant } \\
\text { jurisdiction. }\end{array}$ & $\begin{array}{l}\text { The PBC and MOF should consider an overall review of } \\
\text { the legal and regulatory framework to provide a solid } \\
\text { legal basis to clearance and settlement of operations of } \\
\text { the interbank money market, the OTC bond market and } \\
\text { CCDC. The framework should include the main elements } \\
\text { at the Law level and not only at the Ministry-level } \\
\text { procedures. } \\
\text { The efficiency of the collateral disposal should be } \\
\text { analyzed and improved as soon as possible. } \\
\text { The conflict of law in the cross-border settlement is not } \\
\text { currently an important risk source for securities } \\
\text { settlement in China. However, as the Chinese financial } \\
\text { markets increasingly overact with foreign ones, it is } \\
\text { important that the Chinese legal and regulatory } \\
\text { framework addresses any potential conflict of laws. }\end{array}$ \\
\hline
\end{tabular}




\begin{tabular}{|c|c|}
\hline Reference Recommendation & Recommended Action \\
\hline \multicolumn{2}{|l|}{ Pre-settlement risk } \\
\hline $\begin{array}{l}\text { Recommendation 2. Confirmation of trades between } \\
\text { direct market participants should occur as soon as } \\
\text { possible after trade execution, but no later than trade } \\
\text { date }(\mathrm{T}+0) \text {. Where confirmation of trades by indirect } \\
\text { market participants (such as institutional investors) is } \\
\text { required, it should occur as soon as possible after trade } \\
\text { execution, preferably on } \mathrm{T}+0 \text {, but no later than } \mathrm{T}+1 \text {. }\end{array}$ & $\begin{array}{l}\text { Efforts should be made to ensure that all OTC } \\
\text { transactions are indeed confirmed on } \mathrm{T}+0 \text {. }\end{array}$ \\
\hline $\begin{array}{l}\text { Recommendation } 4 \text {. The benefits and costs of a CCP } \\
\text { should be assessed. Where such a mechanism is } \\
\text { introduced, the CCP should rigorously control the risks } \\
\text { it assumes. }\end{array}$ & $\begin{array}{l}\text { PBC should finalize the process to determine if the } \\
\text { typology of the market and other legal, institutional and } \\
\text { market considerations would justify the establishment of } \\
\text { a CCP mechanism. }\end{array}$ \\
\hline $\begin{array}{l}\text { Recommendation 5. Securities lending and } \\
\text { borrowing (or repurchase agreements and other } \\
\text { equivalent transactions) should be encouraged as a } \\
\text { method for expediting the settlement of securities } \\
\text { transactions. Barriers that inhibit the practice of } \\
\text { lending securities for this purpose should be removed. }\end{array}$ & $\begin{array}{l}\text { CCDC should consider improving securities lending and } \\
\text { borrowing mechanisms beyond the current existing } \\
\text { bilateral arrangements. } \\
\text { Accounting practices and tax rules need to be improved } \\
\text { to facilitate securities lending and borrowing. }\end{array}$ \\
\hline \multicolumn{2}{|l|}{ Settlement risk } \\
\hline $\begin{array}{l}\text { Recommendation 7. CSDs should eliminate principal } \\
\text { risk by linking securities transfers to funds transfers in } \\
\text { a way that achieves DvP. }\end{array}$ & $\begin{array}{l}\text { The settlement of transactions using DvP has strongly } \\
\text { increased since } 2008 \text {. The CCDC is encouraged to further } \\
\text { increase the use of DvP settlement to reach as soon as } \\
\text { possible } 100 \text { percent settlement on a DvP basis. }\end{array}$ \\
\hline $\begin{array}{l}\text { Recommendation 8. Final settlement should occur no } \\
\text { later than the end of the settlement day. Intra-day or } \\
\text { real-time finality should be provided where necessary } \\
\text { to reduce risks. }\end{array}$ & $\begin{array}{l}\text { Protection of settlement finality should be included in the } \\
\text { legal framework. }\end{array}$ \\
\hline \multicolumn{2}{|l|}{ Other issues } \\
\hline $\begin{array}{l}\text { Recommendation 13. Governance arrangements for } \\
\text { CSDs and CCPs should be designed to fulfill public } \\
\text { interest requirements and to promote the objectives of } \\
\text { owners and users. }\end{array}$ & $\begin{array}{l}\text { A clear separation should be made between the oversight } \\
\text { function of the PBC, the other supervisory tasks of } \\
\text { CBRC and MOF, and the operational responsibility of } \\
\text { PBC. } \\
\text { The interests of participants should be explicitly taken } \\
\text { into account. }\end{array}$ \\
\hline $\begin{array}{l}\text { Recommendation 16. SSS should use or } \\
\text { accommodate the relevant international } \\
\text { communication procedures and standards in order to } \\
\text { facilitate efficient settlement of cross-border } \\
\text { transactions. }\end{array}$ & $\begin{array}{l}\text { The CCDC should work to improve the use of relevant } \\
\text { communication procedures and standards and, therefore, } \\
\text { facilitate cross-border trades. }\end{array}$ \\
\hline
\end{tabular}




\begin{tabular}{|c|c|}
\hline Reference Recommendation & Recommended Action \\
\hline $\begin{array}{l}\text { Recommendation 17. CSDs and CCPs should provi } \\
\text { market participants with sufficient information for } \\
\text { them to accurately identify the risks and costs } \\
\text { associated with using the CSD or CCP services. }\end{array}$ & $\begin{array}{l}\text { The CCDC should disclose the answers to the } \\
\text { questionnaire set out in the CPSS/IOSCO disclosure } \\
\text { framework or the answers to the key questions set out in } \\
\text { the assessment methodology for RSSS. }\end{array}$ \\
\hline $\begin{array}{l}\text { Recommendation 18. SSS should be subject to } \\
\text { transparent and effective regulation and oversight. } \\
\text { Central banks and securities regulators should } \\
\text { cooperate with each other and with other relevant } \\
\text { authorities. }\end{array}$ & $\begin{array}{l}\text { Supervisors and regulators should continue to exercise } \\
\text { their action effectively. } \\
\text { The PBC should clarify the roles it plays with respect to } \\
\text { the CCDC by clearly distinguishing its oversight and } \\
\text { supervisory role from its participation in the governance } \\
\text { of the system. } \\
\text { Further fine tuning is needed in the cooperation } \\
\text { arrangements of the different regulators in respect to } \\
\text { clearance and settlement issues. }\end{array}$ \\
\hline $\begin{array}{l}\text { Recommendation 19. CSDs that establish links to } \\
\text { settle cross-border trades should design and operate } \\
\text { such links to reduce effectively the risks associated } \\
\text { with cross-border settlements. }\end{array}$ & $\begin{array}{l}\text { There does not seem to be a comprehensive and } \\
\text { standardized procedure to analyze risks in cross-border } \\
\text { links. This matter should be addressed as soon as possible } \\
\text { by the CCDC and its overseers. }\end{array}$ \\
\hline
\end{tabular}

\section{Main Recommendations}

211. The assessment team found several improvement opportunities, summarized in the Table below:

\section{Table 22. China: Recommended Actions to Improve Observance of CPSS- IOSCO RSSS-Stock Exchange (SSE, SZSE)—SD\&C}

\begin{tabular}{|c|c|}
\hline Reference Recommendation & Recommended Action \\
\hline Pre-settlement risk & \\
\hline $\begin{array}{l}\text { Recommendation } 4 \text {. The benefits and costs of a CCP } \\
\text { should be assessed. Where such a mechanism is } \\
\text { introduced, the CCP should rigorously control the } \\
\text { risks it assumes. }\end{array}$ & $\begin{array}{l}\text { SD\&C today mostly relies on its clearance and settlement } \\
\text { system design and some additional risk control measures } \\
\text { to ensure control of risks. } \\
\text { For the future, SD\&C may consider to evaluate how to } \\
\text { strengthen its robustness as a CCP through a review of } \\
\text { several elements such as monitoring of exposures, stress } \\
\text { tests, availability of financial resources, etc. Exploring } \\
\text { experiences from off-shore peers on this may be useful. } \\
\text { This may become a more immediate priority if SD\&C } \\
\text { wants to accommodate a market evolution to a more } \\
\text { wholesale market for which the current clearance and } \\
\text { settlement design (mostly thought for a retail market) may } \\
\text { not be effective. }\end{array}$ \\
\hline
\end{tabular}




\begin{tabular}{|c|c|}
\hline Reference Recommendation & Recommended Action \\
\hline \multicolumn{2}{|l|}{ Settlement risk } \\
\hline $\begin{array}{l}\text { Recommendation 7. CSDs should eliminate principal } \\
\text { risk by linking securities transfers to funds transfers in } \\
\text { a way that achieves DvP. }\end{array}$ & $\begin{array}{l}\text { CSRC and SD\&C should consider to make public a } \\
\text { description of SD\&C clearance and settlement } \\
\text { arrangements to avoid the perception that by not } \\
\text { following a more "orthodox" DvP structure they do not } \\
\text { comply with the DvP principle. }\end{array}$ \\
\hline $\begin{array}{l}\text { Recommendation 9. CSDs that extend intraday credit } \\
\text { to participants, including CSDs that operate net } \\
\text { settlement systems, should institute risk controls that, } \\
\text { at a minimum, ensure timely settlement in the event } \\
\text { that the participant with the largest payment obligation } \\
\text { is unable to settle. The most reliable set of controls is a } \\
\text { combination of collateral requirements and limits. }\end{array}$ & $\begin{array}{l}\text { SD\&C should perform a comprehensive and deep } \\
\text { assessment of its credit risk exposures as soon as } \\
\text { possible, including possibility of multiple failures. }\end{array}$ \\
\hline $\begin{array}{l}\text { Recommendation 10. Assets used to settle the } \\
\text { ultimate payment obligations arising from securities } \\
\text { transactions should carry little or no credit or liquidity } \\
\text { risk. If central bank money is not used, steps must be } \\
\text { taken to protect CSD members from potential losses } \\
\text { and liquidity pressures arising from the failure of the } \\
\text { cash settlement agent whose assets are used for that } \\
\text { purpose. }\end{array}$ & $\begin{array}{l}\text { Full compliance of the payment systems used to transfer } \\
\text { funds with the CPSIPS should be achieved to ensure that } \\
\text { no settlement risks stem from the clearing and settlement } \\
\text { process due to the existence of liquidity and credit risks in } \\
\text { the payment system. However, the DvP equivalent nature } \\
\text { of the SD\&C settlement arrangements would eventually } \\
\text { limit the risk to market risk. }\end{array}$ \\
\hline \multicolumn{2}{|l|}{ Other issues } \\
\hline $\begin{array}{l}\text { Recommendation 13. Governance arrangements for } \\
\text { CSDs and CCPs should be designed to fulfill public } \\
\text { interest requirements and to promote the objectives of } \\
\text { owners and users. }\end{array}$ & $\begin{array}{l}\text { The SD\&C should develop an action plan to comply with } \\
\text { all RSSSs and the Governance of the system must be } \\
\text { accountable for it and take the necessary actions to } \\
\text { achieve full compliance. }\end{array}$ \\
\hline $\begin{array}{l}\text { Recommendation 16. SSS should use or } \\
\text { accommodate the relevant international } \\
\text { communication procedures and standards in order to } \\
\text { facilitate efficient settlement of cross-border } \\
\text { transactions. }\end{array}$ & $\begin{array}{l}\text { It is advisable that the SD\&C in cooperation with the } \\
\text { exchanges and market participants and in consultation } \\
\text { with the CSRC activate a process to constantly evaluate } \\
\text { the benefits of developments on relevant international } \\
\text { communication procedures and standards and act } \\
\text { promptly to implement the necessary changes to meet } \\
\text { market needs. }\end{array}$ \\
\hline $\begin{array}{l}\text { Recommendation 17. CSDs and CCPs should provide } \\
\text { market participants with sufficient information for } \\
\text { them to identify and evaluate accurately the risks and } \\
\text { costs associated with using the CSD or CCP services. }\end{array}$ & $\begin{array}{l}\text { The SD\&C should disclose the answers to the } \\
\text { questionnaire set out in the CPSS/IOSCO disclosure } \\
\text { framework or the answers to the key questions set out in } \\
\text { the assessment methodology for RSSS. }\end{array}$ \\
\hline $\begin{array}{l}\text { Recommendation 18. SSS should be subject to } \\
\text { transparent and effective regulation and oversight. } \\
\text { Central banks and securities regulators should } \\
\text { cooperate with each other and with other relevant } \\
\text { authorities. }\end{array}$ & $\begin{array}{l}\text { Supervisors and regulators should continue to exercise } \\
\text { their action effectively. } \\
\text { Although a high level cooperation framework among } \\
\text { relevant authorities does exist, cooperation at the } \\
\text { technical level might be structure more formally. }\end{array}$ \\
\hline
\end{tabular}




\begin{tabular}{|l|l|}
\hline \multicolumn{1}{|c|}{ Reference Recommendation } & \multicolumn{1}{c|}{ Recommended Action } \\
\hline & $\begin{array}{l}\text { In addition to existing mechanisms, authorities should } \\
\text { also foster cooperation between them and the private } \\
\text { sector and other relevant stakeholders by creating an } \\
\text { appropriate forum to discuss payment and settlement } \\
\text { matters. }\end{array}$ \\
\hline $\begin{array}{l}\text { Recommendation 19. CSDs that establish links to } \\
\text { settle cross-border trades should design and operate } \\
\text { with cross-border settlements. }\end{array}$ & $\begin{array}{l}\text { In light of the potential internationalization of the Chinese } \\
\text { market, links are likely to become the norm rather than } \\
\text { the exception. The SDC\&C, the exchanges and market } \\
\text { regulators might want to work on a standardized } \\
\text { framework to assess the risks associated to such links, } \\
\text { when the need materializes. }\end{array}$ \\
\hline
\end{tabular}

\section{Table 23. Recommended Actions to Improve Observance of CPSS-IOSCO RCCP-SHFE}

\begin{tabular}{|c|c|}
\hline Recommendation 1. Legal risk & \\
\hline $\begin{array}{l}\text { A CCP should have a well founded, transparent } \\
\text { and enforceable legal framework for each aspect of } \\
\text { its activities in all relevant jurisdictions. }\end{array}$ & $\begin{array}{l}\text { Most key concepts of clearing and settlement are } \\
\text { covered by the SHFE rules and regulations, however, } \\
\text { not in statutory law. In order to observe this } \\
\text { recommendations statutory law should contain } \\
\text { provisions on derivative trading, e.g., the enforceability } \\
\text { of trades, finality, netting, novation, investor protection } \\
\text { and collateral protection. }\end{array}$ \\
\hline Recommendation 4. Margin requirements & \\
\hline $\begin{array}{l}\text { If a CCP relies on margin requirements to limit its } \\
\text { credit exposures to participants, those requirements } \\
\text { should be sufficient to cover potential exposures in } \\
\text { normal market conditions. The models and } \\
\text { parameters used in setting margin requirements } \\
\text { should be risk-based and reviewed regularly. }\end{array}$ & $\begin{array}{l}\text { No clear legal basis exists for the acceptance of } \\
\text { warehouse receipts as collateral to deposit as margin } \\
\text { for the coverage of market risk exposure. This threatens } \\
\text { the stability of the CCP. }\end{array}$ \\
\hline Recommendation 13. Governance & \\
\hline $\begin{array}{l}\text { Governance arrangements for a CCP should be } \\
\text { clear and transparent to fulfil public interest } \\
\text { requirements and to support the objectives of } \\
\text { owners and participants. In particular, they should } \\
\text { promote the effectiveness of a CCP's risk } \\
\text { management procedures. }\end{array}$ & $\begin{array}{l}\text { The SHFE is urged to engage in a self assessment with } \\
\text { the new standards under preparation by the CPSS and } \\
\text { IOSCO which will be released in 2011. A workshop on } \\
\text { these standards might be organized with the } \\
\text { participation of local authorities and market } \\
\text { participants, as well as international practitioners from } \\
\text { both the public and the private sector. }\end{array}$ \\
\hline Recommendation 14. Transparency & \\
\hline $\begin{array}{l}\text { A CCP should provide market participants with } \\
\text { sufficient information for them to identify and } \\
\text { evaluate accurately the risks and costs associated }\end{array}$ & $\begin{array}{l}\text { In order to observe this recommendation the SHFE } \\
\text { should publish the disclosure framework for the CPSS- } \\
\text { IOSCO RCCP. }\end{array}$ \\
\hline
\end{tabular}




\begin{tabular}{|l|l|}
\hline with using its services. \\
\hline Recommendation 15. Regulation and oversight & \\
\hline $\begin{array}{l}\text { A CCP should be subject to transparent and } \\
\text { effective regulation and oversight. In both a } \\
\text { domestic and an international context, central } \\
\text { banks and securities regulators should cooperate } \\
\text { with each other and with other relevant authorities. }\end{array}$ & $\begin{array}{l}\text { Given concentration of risks in a CCP and its potential } \\
\text { effect on financial stability CSRC and PBC should } \\
\text { establish a cooperative oversight framework for CCPs. }\end{array}$ \\
\hline
\end{tabular}

\section{E. Authorities' Response}

212. The PBC and CSRC appreciate the significant undertaking associated with the FSAP review by the IMF and the World Bank in a comprehensive assessment of the SD\&C, CCDC, the SHFE against the CPSS-IOSCO RSSS and for Central Counterparties (RCCP). We would like to pay a high tribute to the great efforts made by all parties involved in the assessment process and the professionalism of the assessors as demonstrated. We recognize the positive and far-reaching influence the assessment has on the stability and effective regulation and oversight of SIPS, clearing and settlement systems.

213. The assessment well objectively reflects the status of the settlement system in China's security market, bond market and futures market as well as the compliance of the SD\&C and CCDC with the RSSS, the compliance of the SHFE with the RCCP. The PBC and CSRC will share and analyze the comments and recommendations in the assessment with the SD\&C, CCDC and SHFE, and consider absorbing and adopting the comments and recommendations in the future. All relevant parties will work together to ensure that SSS in China can operate in a secure, efficient and transparent environment.

214. Meanwhile, the CSRC still holds reservations about certain parts of the assessment of SHFE on its compliance with the RCCP (i.e., Recommendation 1 and Recommendation 4), for the following reasons:

- On the issue of legal basis. Regarding China's legislative system, laws are promulgated by the National People's Congress (NPC), and administrative regulations are issued by the SC. Administrative regulations constitute an important part of China's legal system, providing legal basis for not only administrative regulation, but also the settlement of disputes and cases by judicial authorities. However, it is not an explicit clause after all. The Regulations on the Administration of Futures Trading, which is the administrative regulation governing futures trading, is the legal basis for China's futures market. We do not believe legal gaps exist in China's futures settlement system.

- On the legal recognition of the use of dematerialized warehouse receipts as margin contributions. The use of standardized warehouse receipts as margin contributions is 
clearly stipulated in the Regulations on the Administration of Futures Trading, the Measures for the Administration of Futures Exchanges and the relevant business rules of futures exchanges. The Property Law also contains clearly-stated provisions on pledge right. In practice, the SHFE designates delivery warehouses to serve as the registration authority for the pledge of dematerialized warehouse receipts. There have never been any controversies or disputes in this regard.

215. The PBC holds reservations about certain parts of the assessment of CCDC on its compliance with the RSSS, i.e., Recommendation 1 and Recommendation 8. Since bond is a kind of security, the Securities Law applies to interbank bond market. Also the finality has legal certainty. The regulations issued by PBC indicates, "bond transaction settlement cannot be revoked once completed," "the cash and bonds with the status of waiting for transfer in the settlement process and the collateral regarding to the settlement can only be used for completing the settlement and shall not be enforced compulsorily for other purposes." The spirit and principles of the Securities Law apply to domestic securities market in China, including inter-bank bond market; despite that the Securities Law contains specific provisions more on the exchange market. Regulations promulgated by $\mathrm{PBC}$, which are in accordance with the spirit and principles of the Securities Law and mainly applied to interbank bond market, are the special provisions in Chinese legislation system on securities. According to the Law on Legislation, regulations issued by PBC belong to broadly defined laws and have legal enforceability. Owing to these, inter-bank bond market has been operating smoothly and safely these years since its establishment.

216. The PBC, together with CCDC, will seriously analyze the opinions and suggestions raised in the Assessment Report and keep improving the depositary and settlement system of China's inter-bank bond market. 